\title{
DOSES DE POTÁSSIO E DE MAGNÉSIO EM SOLUÇÃO NUTRITIVA PARA CAPIM-MOMBAÇA
}

\section{WALCYLENE LACERDA MATOS PEREIRA}

Tese apresentada à Escola Superior de Agricultura "Luiz de Queiroz", Universidade de São Paulo, para obtenção do título de Doutor em Agronomia, Área de Concentração: Solos e Nutrição de Plantas.

\section{PIRACICABA}

Estado de São Paulo - Brasil

Novembro - 2001 


\title{
DOSES DE POTÁSSIO E DE MAGNÉSIO EM SOLUÇÃO NUTRITIVA PARA CAPIM-MOMBAÇA
}

\author{
WALCYLENE LACERDA MATOS PEREIRA
}

Engenheira Agrônoma

Orientador: Prof. Dr. FRANCISCO ANTONIO MONTEIRO

Tese apresentada à Escola Superior de Agricultura "Luiz de Queiroz", Universidade de São Paulo, para obtenção do título de Doutor em Agronomia, Área de Concentração: Solos e Nutrição de Plantas.

PIRACICABA

Estado de São Paulo - Brasil

Novembro - 2001 
Dados Internacionais de Catalogação na Publicação (CIP) DIVISÃO DE BIBLIOTECA E DOCUMENTAÇÃO - ESALQ/USP

Pereira, Walcylene Lacerda Matos

Doses de potássio e de magnésio em solução nutritiva para capim-mombaça /

Walcylene Lacerda Matos Pereira. - - Piracicaba, 2001.

124 p. : il.

Tese (doutorado) - Escola Superior de Agricultura Luiz de Queiroz, 2001.

Bibliografia.

1. Capim-mombaça 2. Magnésio 3. Nutrição vegetal 4. Potássio 5. Solução nutritiva I. Título

CDD 633.2

\section{"Permitida a cópia total ou parcial deste documento, desde que citada a fonte - $\mathrm{O}$ autor"}


A Deus pela proteção e força nos momentos difíceis.

À minha mãe Doracy,

pela extrema dedicação e apoio em todas as etapas de minha vida.

AGRADEÇO

À minha família pelo carinho e incentivo.

DEDICO 


\section{AGRADECIMENTOS}

Ao Professor Dr. Francisco Antonio Monteiro, pela sua orientação, amizade e confiança.

À Coordenação de Aperfeiçoamento de Pessoal de Nível Superior (CAPES), pela bolsa de estudos concedida.

À Escola Superior de Agricultura "Luiz de Queiroz" e a Coordenação do Programa de Pós-Graduação em Solos e Nutrição de Plantas pela realização do curso.

Aos Professores Quirino Augusto C. Carmello, Antonio Roque Dechen e Herbert Barbosa de Mattos, pela atenção e colaboração no trabalho de pesquisa.

Ao amigo Jorge Luís Nascimento Soares a minha gratidão pelo incentivo, paciência e dedicação em todos os momentos.

Aos Doutores José Raimundo Natividade Ferreira Gama e Carlos Alberto Veloso pela amizade e apoio em minha carreira.

Aos amigos Waldssimiler T. de Mattos, Cirlene Manarin, Cristiane Carvalho, Pedro Plese, Glaucia Anti, Rosane Rodrigues, Ana Clara Fayal e Marcos Gama pela sincera amizade desenvolvida.

A todos os colegas de pós-graduação, pelos bons momentos que me proporcionaram.

Às funcionárias do Laboratório de Solos e Nutrição de Plantas - ESALQ/USP, Lúcia Forti, Lurdes González, Nivanda Moura, Ednéia Mondoni, Mirtes Sesso, Sueli Bovi e Nancy Amaral pela amizade e auxílio na execução das análises.

Aos Estagiários da Nutrição Mineral de Plantas, em especial, Pelerson Furlan Schiavuzzo, Israel Benetti e José Lavres Júnior pelo apoio na condução dos experimentos. 


\section{SUMÁRIO}

RESUMO

Página

SUMMARY

viii

1 INTRODUÇÃO.

$\mathrm{x}$

2 REVISÃO DE LITERATURA..................................................

2.1 Panicum maximum (Jacq.) cv. Mombaça ................... 3

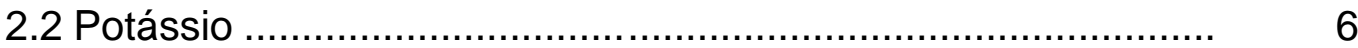

2.3 Potássio em gramíneas forrageiras..........................................

2.4 Magnésio ...................................................................... 10

2.5 Magnésio em gramíneas forrageiras …………………........ 12

2.6 Relação potássio:magnésio .................................................. 13

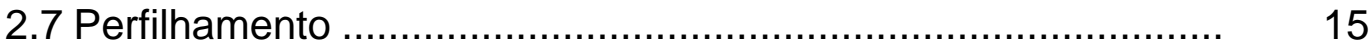

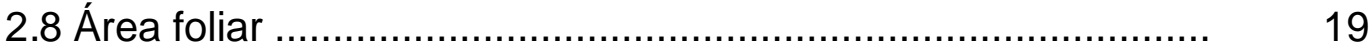

2.9 Estimativa do teor de clorofila pelo valor SPAD ..................... 21

2.10 Nível critico e sintomatologia de deficiência de potássio e magnésio ..................................................................... 25

3. MATERIAL E MÉTODOS …................................................... 29

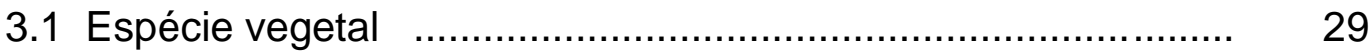

3.2 Local dos experimentos .................................................... 29

3.3 Delineamento experimental ................................................ 29

3.4 Instalação e condução dos experimentos ............................... 30

3.5 Experimento com doses de potássio ..................................... 31 
3.6 Experimento com doses de magnésio ................................... 32

3.7 Perfilhamento .................................................................. 33

3.8 Estimativa do teor de clorofila …….................................... 34

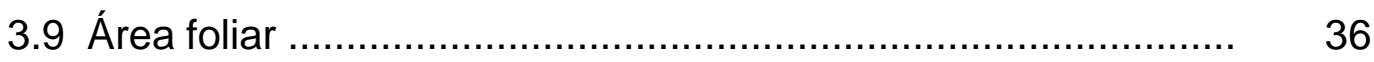

3.10 Determinações no material vegetal ...................................... 36

3.10.1 Produção de matéria seca ................................................ $\quad 36$

3.10.2 Análises químicas ....................................................... 36

3.10.3 Acúmulo de nutriente ..................................................... 37

3.10.4 Relação K:Mg de nutriente ............................................. 37

3.11 Análises estatística .......................................................... 37

4 RESULTADOS E DISCUSSÃO................................................ 38

4.1 Experimento com doses de potássio ................................... 38

4.1.1 Produção de matéria seca da parte aérea e das raízes ......... 38

4.1.2 Número de perfilhos ......................................................... 42

4.1.3 Área foliar ................................................................... 45

4.1.4 Estimativa do teor de clorofila em valor SPAD ..................... 47

4.1.5 Concentração de potássio nos tecidos vegetais .................... 48

4.1.5.1 Folhas emergentes .................................................. 48

4.1.5.2 Lâminas de folhas recém-expandidas ................................. 50

4.1.5.3 Lâminas de folhas maduras ............................................. 53

4.1.5.4 Colmos mais bainhas .................................................... 56

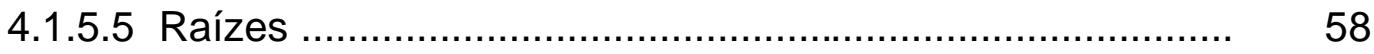

4.1.6 Acúmulo de potássio nos componentes da planta ................. 59

4.1.7 Nível crítico de potássio ...................................................... 63

4.1.8 Relação K:Mg no capim-Mombaça ....................................... 66

4.1.9 Sintomas visuais de deficiência de potássio ......................... 68

4.2 Experimento com doses de magnésio ..................................... 71

4.2.1 Produção de matéria seca da parte aérea e das raízes ......... 71

4.2.2 Número de perfilhos ........................................................... 
4.2.3 Área foliar ............................................................................. 77

4.2.4 Estimativa do teor de clorofila em valor SPAD ..................... $\quad 79$

4.2.5 Concentração de magnésio nos tecidos vegetais ................... 81

4.2.5.1 Folhas emergentes ….................................................. 81

4.2.5.2 Lâminas de folhas recém-expandidas ................................ 83

4.2.5.3 Lâminas de folhas maduras ............................................ $\quad 85$

4.2.5.4 Colmos mais bainhas ................................................... 87

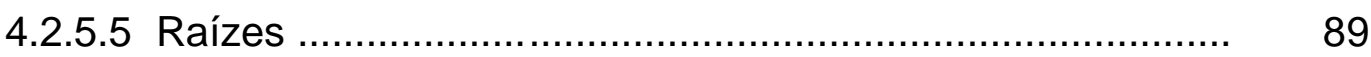

4.2.6 Acúmulo de magnésio nos componentes da planta .............. $\quad 90$

4.2.7 Nível crítico de magnésio ................................................. 94

4.2.8 Relação entre concentração de magnésio e valor SPAD ...... 96

4.2.9 Relação K:Mg no capim-Mombaça ....................................... 98

4.2.10 Sintomas visuais de deficiência de magnésio ...................... 100

5 CONCLUSÕES .............................................................. 103

REFERÊNCIAS BIBLIOGRÁFICAS ............................................ 104 


\title{
DOSES DE POTÁSSIO E DE MAGNÉSIO EM SOLUÇÃO NUTRITIVA PARA CAPIM-MOMBAÇA
}

\author{
Autora : Walcylene Lacerda Matos Pereira \\ Orientador : Prof. Dr. Francisco Antonio Monteiro
}

\section{RESUMO}

Foram conduzidos dois experimentos em casa-de-vegetação com o Panicum maximum cv. Mombaça cultivado em solução nutritiva, tendo sílica como substrato. Um experimento envolveu oito doses de potássio $(0 ; 9,75 ; 39 ; 78$; 156; 234; 312 e $\left.468 \mathrm{mg} \mathrm{L}^{-1}\right)$ e o outro oito doses de magnésio $(0 ; 1,2 ; 3,6 ; 12$; 24; $36 ; 48$ e $60 \mathrm{mg} \mathrm{L}^{-1}$ ), sendo ambos conduzidos no período de janeiro a março de cada ano. O objetivo foi o de estudar o efeito das doses de potássio e magnésio na produção de massa seca, no número de perfilhos, na área foliar, no teor de clorofila estimado através da leitura SPAD, na concentração e acúmulo destes nutrientes nos componentes da planta e na determinação do nível crítico. O delineamento estatístico foi de blocos completos ao acaso, com quatro repetições. Observourse efeito significativo e positivo das doses de potássio na produção de massa seca da parte aérea e das raízes, expressado por regressão quadrática e também na área foliar, representada por efeito linear. As doses de potássio afetaram significativamente o número de perfilhos, 
porém não influenciaram no teor de clorofila da lâmina foliar. A concentração de potássio nas folhas emergentes, nas lâminas de folhas recém-expandidas, nas lâminas de folhas maduras, nos colmos mais bainhas e nas raízes aumentou significativamente com o incremento de potássio na solução nutritiva. O maior e menor acúmulo de potássio na massa seca da parte aérea foram observados nos colmos mais bainhas e nas lâminas de folhas maduras, respectivamente. Observou-se efeito significativo positivo das doses de magnésio na produção de massa seca da parte aérea e das raízes, na área foliar e na estimativa do teor de clorofila, sendo representados por regressões quadráticas e lineares em função da variável estudada. As doses de magnésio aumentaram o número de perfilhos até a dose de $48 \mathrm{mg} \mathrm{L}^{-1}$. A concentração de magnésio nas folhas emergentes, nas lâminas de folhas recém-expandidas, lâminas de folhas maduras, nos colmos mais bainhas e nas raízes aumentou significativamente com o incremento de magnésio na solução nutritiva até a máxima dose estudada. O maior e menor acúmulo de magnésio na massa seca da parte aérea foram constatados nos colmos mais bainhas e nas lâminas de folhas emergentes, respectivamente. As lâminas de folhas recém-expandidas foram consideradas indicadoras para a avaliação do estado nutricional do capimMombaça associadas ao nível crítico de potássio entre 15,4 e $17,3 \mathrm{~g} \mathrm{~kg}^{-1}$ de massa seca e de magnésio de $4,2 \mathrm{~g} \mathrm{~kg}^{-1}$. 


\section{POTASSIUM AND MAGNESIUM RATES IN NUTRIENT SOLUTION FOR MOMBAÇA GRASS}

Author: Walcylene Lacerda Matos Pereira Adviser: Prof. Dr. Francisco Antonio Monteiro

\section{SUMMARY}

Two experiments were carried out in greenhouse conditions with Panicum maximum cv. Mombaça grown in nutrient solution, using ground quartz as substrate. One experiment had eight potassium rates $(0 ; 9.75 ; 39 ; 78 ; 156 ; 234$; 312 and $\left.468 \mathrm{mg} \mathrm{L}^{-1}\right)$ and another had eight magnesium rates $(0 ; 1.2 ; 3.6 ; 12$; 24; 36; 48 and $60 \mathrm{mg} \mathrm{L}^{-1}$ ) and were performed from January to March in each year. The objective was to evaluate the effects of potassium and magnesium rates on dry matter yield, tiller number, leaf area, chlorophyll concentration in the leaves throught SPAD readings, accumulation and concentration of each nutrient in plant components, and to estabilish parameters to determine the critical level of these two nutrients. In each experiment a complete randomized block design was used, with four replications. There was a positive effect of potassium rates in the dry matter yield of plant tops and roots, that fitted on quadratic models and in the leaf area expressed by linear models. Potassium rates affected the tiller number, but did not influence the estimated chlorophyll concentration in leaves. Potassium concentration in the emerging leaves, 
lamina of recently expanded leaves, lamina of mature leaves, stems plus sheaths and roots increased with potassium increasing in the nutrient solution. The highest and lowest potassium accumulation in the dry matter of plant tops were observed in stems plus sheaths and lamina of mature leaves, respectively. A positive effect of magnesium rates was observed in the dry matter of plant tops and root, in leaf area, in chlorophyll concentration, and they fitted in quadratic and linear models according to the studied variable. Magnesium rates in solution increased the tiller number up to $48 \mathrm{mg} \mathrm{L}^{-1}$. The concentration of magnesium in the emerging leaves, lamina of recently expanded leaves, lamina of mature leaves, stems plus sheaths and roots increased with magnesium solution from 0 to $60 \mathrm{mg} \mathrm{L}^{-1}$. The highest and lowest accumulation of magnesium in the dry matter of plant tops were observed in the stems plus sheaths and emerging leaves, respectively. The lamina of recently expanded leaves showed to be suitable for the evaluation of the nutricional status in potassium and magnesium of the Mombaça grass and the critical level were 15.4 and $17.3 \mathrm{~g} \mathrm{~kg}^{-1}$ for potassium and $4.2 \mathrm{~g} \mathrm{~kg}^{-1}$ for magnesium. 


\section{INTRODUÇÃO}

A exploração pecuária de uma determinada região está intimamente associada ao seu potencial de produção de forragens, visto que a pastagem é a mais importante, quando não a única fonte para a alimentação de herbívoros e, indubitavelmente a mais econômica. Entretanto, o rebanho de bovinos é mantido em pastagens implantadas sem qualquer tipo de tecnologia e nos primeiros anos de formadas as pastagens apresentam alta capacidade de suporte. Porém, com o passar dos anos vão se degradando, em decorrência da queda na fertilidade dos solos, do aumento de plantas invasoras e do manejo inadequado.

A necessidade de intensificar a produção animal tem aumentado o interesse na formação de pastagens cultivadas e a espécie Panicum maximum tem ocupado lugar de destaque, especialmente em áreas com solos de fertilidade natural média a elevada, provavelmente pela sua alta capacidade de produção de massa seca por unidade de área. Por essa razão, grande quantidade de esforços e recursos têm sido investidos em programas de seleção e avaliação de cultivares desse gênero, o que tem resultado em liberação de novos cultivares como Tobiatã, Centenário, Aruana, Tanzânia e Mombaça, nos anos recentes.

Entretanto, a implantação indiscriminada de novos cultivares em associação ao desconhecimento generalizado de várias espécies de plantas forrageiras disponíveis, levam pouco tempo para gerar um quadro muito desfavorável em termos de rentabilidade econômica da atividade. 
Neste contexto sobressai a necessidade de estudos sobre princípios básicos que expliquem como a produção, qualidade das pastagens e o consumo de forragens pelos animais podem ser alteradas. Aumentar a produtividade dessas pastagens, através da aplicação de fertilizantes, permite atingir um nível de exploração animal mais intensiva capaz de competir com outras formas de atividade agrícola.

Para que o potencial de cultivares recentemente lançados de Panicum possa ser racionalmente explorado há que se entender a demanda dos mesmos por nutrientes. Entretanto, há uma escassez de informações sobre a nutrição mineral desses cultivares, e particularmente essa situação é da maior relevância para o cultivar Mombaça. Estudos destinados a identificar a parte diagnóstica para fins de avaliação nutricional, a determinação do nível crítico do nutriente, além de respostas fisiológicas e bioquímicas que este cultivar apresenta quando desenvolvido em doses de nutrientes são imprescindíveis para se obter uma adequada nutrição da planta.

Assim, o propósito deste trabalho foi o de avaliar as respostas do Panicum maximum cv. Mombaça, cultivado em solução nutritiva, a doses de potássio e magnésio quanto à produção de massa seca, ao número de perfilhos, ao teor de clorofila estimado através da leitura SPAD, àárea foliar, ao nível crítico do nutriente, à concentração e o acúmulo desses nutrientes nos componentes da planta. 


\section{REVISÃO DE LITERATURA}

\subsection{Panicum maximum Jacq. cv. Mombaça}

A busca por materiais genéticos superiores para gramíneas forrageiras tropicais teve forte incremento no Brasil por volta dos anos 80 . Recentemente foram lançados os primeiros cultivares de Panicum maximum resultantes de trabalhos de melhoramento genético e/ou seleção realizados no Brasil (Jank, 1995).

Aronovich (1995) descreveu que o local de origem do Panicum maximum Jacq. é a África tropical. A sua introdução no Brasil rão está bem documentada mas, possivelmente, sua introdução ocorreu na época da escravatura quando era utilizado como cama para os escravos nas embarcações vindas da África e se alastrou nos locais onde os barcos eram descarregados. Uma vez no Brasil, se espalhou e se adaptou tão bem, que hoje é considerado nativo em muitas regiões do país. O Panicum maximum é uma gramínea que possui alta produção de massa seca, tolerância a pragas e enfermidades, além de apresentar alto valor nutritivo (Vallejos et al., 1989).

O Panicum maximum Jacq. cultivar Mombaça faz parte da coleção africana de 426 tipos da espécie Panicum maximum, pesquisada desde 1982 no Centro Nacional de Pesquisa de Gado de Corte, unidade da Embrapa em Campo Grande-MS. O cultivar foi lançado em 1993 e é originário da África, onde foi coletado pelo Institut Français de Recherche Scientifique pour le Développement en Coopération - ORSTOM (Jank , 1995). 
Segundo Savidan et al. (1990), o capim-Mombaça é uma planta cespitosa, chegando a ter cerca de $1,65 \mathrm{~m}$ de altura e folhas com aproximadamente $3 \mathrm{~cm}$ de largura. Os colmos são levemente arroxeados. As lâminas possuem poucos pêlos na face superior e as bainhas são glabras, mas ambas não apresentam cerosidade. A inflorescência é uma panícula com ramificações primárias longas e secundárias apenas nas bases.

O capim-Mombaça, tal qual a maioria dos outros cultivares de Panicum maximum, necessita de manejo adequado para um bom e rápido estabelecimento, assim como para cobertura total do solo. Os resultados quanto a exigência nutricional até o momento, mostram que o cultivar Mombaça é mais eficiente que o cultivar Tanzânia na utilização do fósforo. Quanto àsaturação por bases a faixa mais adequada de produtividade tem sido encontrada entre 30 e 45\% (Capim....., 1994).

Em estudos comparativos de cultivares do Panicum maximum, Jank (1995) encontrou que o cultivar Mombaça produziu 136\% mais massa seca que o capim-Colonião e $28 \%$ mais que o cultivar Tanzânia, em parcelas sob cortes manuais. A porcentagem de crescimento na seca foi de $11 \%$ do total anual, apresentou $82 \%$ de folhas durante $\mathrm{o}$ ano, produzindo $33 \mathrm{t} \mathrm{ha}^{-1}$ ano $^{-1}$ de massa seca foliar, resultados esses semelhantes aos do cultivar Tanzânia-1, mas muito superiores aos do Colonião.

Em experimento com oito cultivares de Panicum maximum, o capim-Mombaça foi um dos cultivares que apresentou maior produção de massa seca total e em cortes realizados a cada 35 dias no verão e 70 dias no inverno, e mostrou uma produção por corte de $7.186 \mathrm{~kg} \mathrm{ha}^{-1} \mathrm{e}$ $2.483 \mathrm{~kg} \mathrm{ha}^{-1}$, respectivamente (Cecato et al., 1996).

O cultivar Mombaça, foi classificado como o sexto melhor entre 156 acessos de Panicum maximum em produção de massa seca foliar, sendo esta produção suficiente para aumentar significativamente a lotação de pastagens (Corsi \& Santos, 1995). Na Estação Experimental de Paranavaí-PR do IAPAR, 
o cultivar Mombaça apresentou taxa de lotação de 1,80 unidade animal (UA) por hectare, com ganho de peso de $720 \mathrm{~kg} \mathrm{ha}^{-1}$ ano $^{-1}$ (Jank et al., 1994).

Em avaliação de ecotipos do gênero Panicum maximum sob pastejo, em pequenas parcelas, o capim-Mombaça destacou-se pelo número de animais que a pastagem suportou por unidade de área, além da maior porcentagem de folhas e de massa verde seca durante o período das águas e seca, com valores de 73 e $41 \mathrm{~kg} \mathrm{ha}^{-1} \mathrm{dia}^{-1}$, respectivamente, e apresentou maior taxa de crescimento durante as chuvas (Corsi \& Santos, 1995).

Santos, P. (1997), objetivando estudar algumas características dos cultivares Tanzânia e Mombaça submetidos a três intervalos entre pastejo ao longo de um ano no município de Piracicaba, obteve resultados em que o resíduo pós-pastejo foi superior para o capim-Mombaça que variou na média de $2.300 \mathrm{~kg} \mathrm{ha}^{-1}$ em relação ao Tanzânia que teve $1.900 \mathrm{~kg} \mathrm{ha}^{-1}$. Verificou ainda que estes cultivares devem ser pastejados com mais de 48 dias entre maio e setembro, enquanto o capim-Mombaça deve ser pastejado com menos de 28 dias de intervalo no período de novembro a maio e o capim-Tanzânia com menos de 38 dias entre novembro a abril.

Em experimento de três anos realizado pela Embrapa sob um sistema de pastejo flexível, os cultivares Mombaça e Tobiatã permitiram alcançar 14 dias sob pastejo no período da seca e o período de descanso de 60 dias, para ambos. No período das águas, no entanto, o capim-Tobiatã possibilitou 12 dias sob pastejo com 37 dias de período de descanso, enquanto o capim-Mombaça, foi pastejado por 14 dias com 35 dias de período sob descanso. Estes resultados propiciaram estimativas da capacidade de suporte de $2 \mathrm{UA} \mathrm{ha}^{-1}$ para o Tobiatã e 2,3 UA ha-1 para o Mombaça. Essa diferença na capacidade de suporte foi devido àmaior porcentagem de folhas apresentadas pelo Mombaça, que foi em média durante o ano, de $47 \%$ e para o Tobiatã $38 \%$ (Capim ..., 1994).

O capim-Mombaça, por ter maior porte e apresentar mais elevada produção que o capim-Tanzânia, dependendo das condições locais, poderá ter 
êxito em sistemas de pastejo intensivo e rotacionado com adição de nutrientes (Jank, 1995). Entretanto, em avaliação realizada no Estado do Pará por Dias Filho et al. (1995), o cultivar não foi indicado como promissor para a região, devido seu baixo vigor, baixa capacidade de cobertura do solo, alta susceptibilidade a doenças e aparecimento de sintomas de deficiência nutricional, apesar de ter produção apropriada de massa seca e relação folha:haste.

\subsection{Potássio}

O potássio é absorvido pelas raízes na forma de $\mathrm{K}^{+}$, sendo o processo essencialmente ativo. $O$ nutriente se redistribui das folhas e órgãos mais velhos para os mais novos, e por conseguinte os sintomas de deficiência de potássio se manifestam em primeiro lugar nas folhas velhas como uma clorose seguida de necrose das pontas e margens (Malavolta, 1980).

O nutriente tem ação fundamental no metabolismo vegetal, pelo papel que exerce na fotossíntese, atuando na transformação da energia luminosa em energia química (Werner, 1986). É também responsável pela translocação dos carboidratos sintetizados no processo fotossintético e age como ativador de enzimas (Epstein, 1975).

Para Coelho \& Verlengia (1973) o potássio, embora esteja presente em todas as células vivas, não é uma parte integrante da célula, nem possui uma função completamente esclarecida. Dentro da célula é encontrado no citoplasma, nos vacúolos e em menor quantidade no núcleo. Ocorre primariamente na forma iônica ou ligado à superfície dos colóides, não estando associado a qualquer composto específico dentro da célula.

Mello et al. (1989) relataram que o potássio não faz parte de compostos orgânicos estruturais da planta. Nos vegetais, faz-se presente sob a forma iônica no suco celular e na seiva, ou então, adsorvido æ̀s proteínas do 
protoplasma sendo um elemento mineral muito móvel nos tecidos. Devido a essa mobilidade, o potássio é facilmente perdido pelas folhas e pelas raízes e o conteúdo do nutriente no vegetal diminui com o avanço de idade da planta. Na matéria orgânica encontra-se quase totalmente na forma trocável, ou seja, adsorvido \&̀s cargas negativas dos colóides orgânicos.

O potássio participa, direta ou indiretamente, dos processos bioquímicos envolvendo o metabolismo dos carboidratos, sendo ativador de enzimas como sintetases, as oxi-redutases, desidrogenases e quinases. Também atua na assimilação de $\mathrm{CO}_{2}$, na formação de proteínas e na síntese, translocação e armazenamento de açúcares (Braga, 1996).

Experimentos com potássio, nos quais foram comparados plantas deficientes e não-deficientes, demonstraram que esse elemento está relacionado com quase todas as funções fisiológicas que ocorrem dentro da planta. Assim, na fotossíntese parece determinar maior utilização da luz, notadamente nos períodos frios e encobertos, isto é, com baixa luminosidade (Coelho \& Verlengia, 1973).

Mediante a mineralização dos compostos orgânicos do solo, pela atividade microbiana, o potássio é liberado, passando, então, para formas solúvel ou trocável, podendo com isso ser aproveitado pelas plantas (Miyasaka \& Okamoto,1992).

\subsection{Potássio em gramíneas forrageiras}

Ferrari Neto (1991), utilizando a técnica do elemento faltante, verificou que a produção dos capins Braquiária (Brachiaria decumbens) e Colonião (Panicum maximum) foi influenciada pelo potássio, pois na ausência do elemento a produção dessas plantas forrageiras correspondeu a $30 \%$ da massa seca produzida no tratamento completo, na soma de dois cortes. 
Estudos desenvolvidos por Silva et al. (1995), sob sete doses de potássio $(0 ; 975 ; 39 ; 78 ; 156 ; 234$ e 312 mg L-1) no capim-Tanzânia-1, demonstraram respostas lineares positivas às doses de potássio na solução nutritiva para a produção de massa seca de lâminas de folhas maduras e de colmos mais bainhas, como também efeitos positivos do elemento na produção de massa seca das lâminas de folhas recém-expandidas, da parte aérea como um todo e no perfilhamento do capim.

Teixeira (1987), em estudo com potássio, em solo de pastagem com Brachiaria brizantha cv. Marandu, verificou que os animais consomem todo o potássio da gramínea por ser o sal mineral isento desse elemento. De $51,33 \mathrm{~kg} \mathrm{ha}^{-1}$ ano $^{-1}$ de potássio consumido pelos animais somente $0,86 \%$ ficou estocado nos animais, sendo a maior parte $(99,14 \%)$, retornada ao pasto pelas fezes e urina. O retorno do potássio ao solo pelas excreções ocorre com uma distribuição desuniforme no pasto. Monteiro \& Werner (1997) ressaltaram que a forragem não consumida pelos animais apresenta-se também como uma fonte importante de retorno de nutrientes para o sistema, destacando a distribuição uniforme das plantas na área da pastagem. De acordo com Wilkinson \& Lowrey (1973), o retorno do potássio decorrente dos tecidos mortos da parte aérea e raízes das plantas, e pelas lavagens das folhas é de aproximadamente $97,3 \mathrm{~kg} \mathrm{ha}^{-1} \mathrm{ano}^{-1}$.

Conduzindo experimento de omissão de nutrientes em solução nutritiva com Brachiaria brizantha cv. Marandu, Monteiro et al. (1995) verificaram que a omissão de potássio, quando comparada com o tratamento completo, não resultou em limitações significativas na produção de massa seca e no perfilhamento, porém as concentrações de potássio na parte aérea $\left(4,3 \mathrm{~g} \mathrm{~kg}^{-1}\right)$ e nas raízes $\left(3,6 \mathrm{~g} \mathrm{~kg}^{-1}\right)$ foram significativamente inferiores aos encontrados no tratamento completo (28,0 e $25,0 \mathrm{~g} \mathrm{~kg}^{-1}$, respectivamente).

Mattos (1997), avaliando o efeito das doses de potássio (0; 975; 39; 78; 156; 234; 312 e $468 \mathrm{mg} \mathrm{L}^{-1}$ ) nas gramíneas forrageiras Brachiaria brizantha cv. Marandu e Brachiaria decumbens cv. Basilisk, obteve respostas favoráveis 
às doses utilizadas quanto à produção de massa seca da parte aérea e das raízes, ao número de perfilhos e à concentração do nutriente nos tecidos. A máxima produção de massa ocorreu com doses de potássio entre 445 e $531 \mathrm{mg} \mathrm{L}^{-1}$ na Brachiaria decumbens e entre 365 e $399 \mathrm{mg} \mathrm{L}^{-1}$ na Brachiaria brizantha. Os níveis críticos estiveram entre 20 e $23 \mathrm{~g} \mathrm{~kg}^{-1}$ nas lâminas de folhas recém-expandidas na Brachiaria decumbens enquanto para Brachiaria

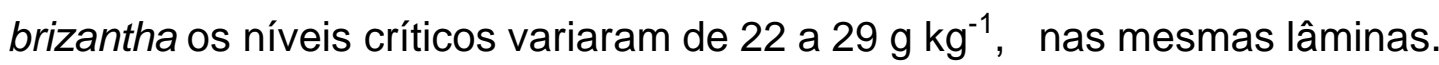

Andrade et al. (1996), avaliando respostas de Panicum maximum à fertilização nitrogenada e potássica, constataram que a adubação nitrogenada teve efeito positivo na produção de massa seca, porém o efeito dependeu da aplicação de potássio. $\mathrm{Na}$ ausência de potássio, a resposta ao nitrogênio foi limitada, enquanto na presença de potássio na adubação a resposta ao nitrogênio foi acentuada.

Silva et al. (1997), em experimento num esquema fatorial com doses de potássio (78; 156; 234 e $\left.312 \mathrm{mg} \mathrm{L}^{-1}\right)$ e de sódio $\left(11,5\right.$ e $\left.69 \mathrm{mg} \mathrm{L}^{-1}\right)$ para o capim-Tanzânia-1 cultivado em solução nutritiva, evidenciaram efeito significativo das doses de potássio na produção de massa seca da parte aérea do capim, independentemente do suprimento de sódio. Porém, tanto a produção de massa seca de raízes como o perfilhamento não responderam significativamente às doses de potássio e de sódio. O fornecimento de potássio promoveu aumento na concentração deste nutriente nas lâminas de folhas recém-expandidas e nos colmos+bainhas do capim, tanto no primeiro como no segundo cortes.

Em experimento para avaliar a influência das adubações nitrogenada e potássica na produção de massa seca e na fisiologia de perfilhamento do capim-Setária (Setária anceps Stapf Ex. Massey cv. Kazungula), Herling et al. (1991) verificaram que adubação com potássio somente apresentou resultados significativos na produção de massa seca e não teve interferência no perfilhamento. 
Conduzindo experimento com doses de potássio em Brachiaria decumbens e Panicum maximum cv. Colonião, Faquin et al. (1995) verificaram incrementos significativos na produção de massa seca da parte aérea das plantas forrageiras, nos dois cortes e no total dos cortes, cujas equações de regressão mostraram uma relação quadrática para as doses de potássio, para ambas as espécies. No total dos cortes, a produção de massa seca em função das doses de potássio variou em quase quatro vezes no capim-Braquiaria e em quase cinco vezes no capim-Colonião. O efeito das doses de potássio não foi suficiente para promover diferenças significativas no perfilhamento do Panicum maximum cv. Colonião, enquanto, na Brachiaria decumbens essa significância foi verificada.

$\mathrm{Na}$ literatura, estudos referentes a respostas de gramíneas forrageiras a adubação potássica, em sua maioria, estão associados à adubação nitrogenada e/ou à fosfatada. Ferrari Neto (1991) ressaltou que não têm sido encontradas respostas tão acentuadas ao potássio pelas gramíneas forrageiras, sendo mais freqüentes os trabalhos com ausência de resposta (Serrão \& Simão Neto, 1971 e Paulino et al., 1986).

\section{$2.4 \quad$ Magnésio}

As plantas absorvem o magnésio como $\mathrm{Mg}^{2+}$. Uma função importante do magnésio na planta refere-se à sua presença na clorofila, em que ocupa o centro de uma estrutura planar formada por um anel tetrapirrólico. O magnésio é móvel na planta, de modo que os sintomas típicos de carência (clorose internerval) começam a aparecer nas lâminas de folhas maduras (Malavolta et al., 1997).

Esse nutriente também acha-se relacionado com o transporte de carboidratos nas plantas. O baixo conteúdo de carboidratos observado em algumas plantas é devido à baixa atividade fotossintética resultante de 
insuficiente suprimento de magnésio. Ele se concentra mais nas folhas e acumula-se nas partes em crescimento do caule e raízes (Coelho \& Verlengia, 1973).

O magnésio ativa mais enzimas do que qualquer outro nutriente. É também, cofator de quase todas enzimas fosforilativas, formando uma ponte entre o pirofosfato do trifosfato de adenosina (ATP) ou do difosfato de adenosina (ADP) e a molécula da enzima. A transferência de energia desses dois compostos é fundamental nos processos de fotossíntese, respiração, reação de síntese dos compostos orgânicos, absorção iônica e trabalho mecânico realizado pela planta (Malavolta, 1980).

O magnésio não é um elemento normalmente empregado em adubações. Entretanto, seu suprimento é feito usualmente através da calagem utilizando calcário, e particularmente com o uso do calcário dolomítico (Raij, 1991). No Brasil, não é comum ocorrerem registros de deficiência desse nutriente nas plantas forrageiras, porém a diminuição da concentração de magnésio nessas plantas pode ocasionar a "tetania das pastagens" em bovinos (Fonseca \& Meurer, 1995).

De conformidade com Malavolta (1976), a deficiência de magnésio geralmente ocorre sob condições onde a deficiência de cálcio também é problema. A baixa disponibilidade de magnésio no solo pode ser observada principalmente nas regiões de solo sob cerrado, onde $90 \%$ das áreas tem solo com baixa disponibilidade nesse elemento (Lopes, 1984).

Uma proporção relativamente alta do magnésio nos restos vegetais incorporados ao solo, que darão origem ao húmus, está presente na clorofila. A concentração de magnésio na massa orgânica do solo deve ser aproximadamente dez vezes menor que a do potássio (Malavolta, 1976). 


\subsection{Magnésio em gramíneas forrageiras}

Corrêa (1996), avaliando o efeito de doses de nitrogênio (42; 210 e $\left.378 \mathrm{mg} \mathrm{L}^{-1}\right)$ e de magnésio $\left(4,8\right.$ e $\left.48 \mathrm{mg} \mathrm{L}^{-1}\right)$ em três cultivares de Panicum maximum, observou que somente quando o nitrogênio foi fornecido em dose mais alta o suprimento de magnésio apresentou efeito significativo na produção de massa seca da parte aérea e das raízes dos capins.

Estudando o efeito das doses de magnésio $(0 ; 1,2 ; 3 ; 6 ; 12 ; 36 ; 48$ e $60 \mathrm{mg} \mathrm{L}^{-1}$ ), em experimento com solução nutritiva, no rendimento da massa seca e distribuição da produção da parte aérea em Brachiaria brizantha cv. Marandu, Sarkis et al. (1996) acrescentaram que o magnésio influiu significativamente na produção de massa seca das plantas em ambos os cortes. A participação porcentual das lâminas de folhas novas na produção variou de 40 a $47 \%$ e de 32 a $35 \%$ para o primeiro e segundo crescimentos, respectivamente. Porém, a contribuição das lâminas de folhas maduras foi menor, para ambos os crescimentos, quando comparado com as lâminas de folhas novas e colmos mais bainhas.

Em experimento com a combinação de doses de fósforo $(3,1 ; 15,5$ e $\left.31 \mathrm{mg} \mathrm{L}^{-1}\right)$ e de magnésio $\left(4,8 ; 24 ; 48\right.$ e $\left.72 \mathrm{mg} \mathrm{L}^{-1}\right)$ para a produção e nutrição de Brachiaria brizantha cv. Marandu e Brachiaria decumbens, Almeida (1998) obteve mais elevada concentração de fósforo nessas plantas forrageiras com o aumento das doses de magnésio. Entretanto, as duas espécies apresentaram capacidade de absorção de altas quantidades de magnésio.

Gomide et al. (1986) testaram calagem e doses de fósforo no estabelecimento e na produção do capim-Colonião no cerrado. Verificaram interações entre calagem e fosfato de rocha e aumentos da concentração de magnésio na parte aérea da planta forrageira de $1,6 \mathrm{~g} \mathrm{~kg}^{-1}$ para $2,0 \mathrm{~g} \mathrm{~kg}^{-1}$.

Avaliando a concentração de magnésio na massa seca em 280 gramíneas forrageiras Skerman \& Riveros (1982) verificaram uma variação de 0,4 a $9,0 \mathrm{~g} \mathrm{~kg}^{-1}$, tendo a média permanecido ao redor de $3,6 \mathrm{~g} \mathrm{~kg}^{-1}$. 
Pesquisadores do Centro Internacional de Agricultura Tropical - CIAT (1984), trabalhando com pastagens de Brachiaria humidicola em degradação, obtiveram aumento significativo na produção de massa seca com a aplicação de magnésio de $10 \mathrm{~kg} \mathrm{ha}^{-1}$, o que evidenciou a importância do emprego do magnésio como nutriente e não como corretivo de acidez .

Monteiro et al. (1995), em experimento com omissões de nutrientes em solução nutritiva para Brachiaria brizantha cv. Marandu, constataram uma redução de $45 \%$ na produção de massa seca da parte aérea, de $70 \%$ nas raízes e de $32 \%$ no número de perfilhos, quando compararam a omissão do magnésio com o tratamento completo.

\subsection{Relação potássio:magnésio}

A interação do magnésio com o potássio freqüentemente pode ocorrer nas plantas cultivadas em solos pobres em magnésio ou para culturas que requerem altas quantidades de potássio para uma elevada produção e boa qualidade (Raij, 1982).

A interferência negativa de um íon na absorção de outro, como acontece entre o potássio e magnésio, é denominada antagonismo (Santos, 1992). Os mecanismos envolvidos no processo antagônico entre os cátions cálcio, magnésio e potássio parece não estar bem nítido, pois não são bem conhecidos. Algumas propostas apresentadas em trabalhos de pesquisa sugerem que o fenômeno se origina na raiz, outras porém ressaltam que a origem seria na translocação destes cátions para a parte aérea das plantas (Soares, 1975).

Para verificar a relação antagônica entre os nutrientes potássio e magnésio, Fonseca \& Meurer (1995) conduziram um experimento com milho (Zea mays) em solução nutritiva, utilizando doses de potássio. Verificaram que o acúmulo de magnésio foi reduzido tanto nas raízes como na parte aérea das 
plantas, com o aumento da concentração do potássio na solução nutritiva e os resultados sugeriram que o antagonismo entre potássio e magnésio origina-se no processo de absorção dos dois nutrientes pelas raízes.

A deficiência de magnésio causada pelo excesso de potássio, nas condições brasileiras, tem sido observada em solos ácidos, onde são utilizadas fórmulas de adubação relativamente ricas em potássio. Alta quantidade de potássio no solo poderá, de alguma maneira, dificultar a absorção do magnésio e com isso afetar suas funções na planta, interferindo no seu metabolismo. (Malavolta, 1976).

Soares (1978) demostrou que o aumento na quantidade absorvida de um cátion na planta, de maneira geral, reduz a quantidade de um ou mais cátions. Ainda, o mesmo autor relatou que tanto o potássio pode reduzir a absorção de cálcio e/ou magnésio, como estes podem diminuir a absorção do potássio.

Ventura (1987), estudando a influência das doses de potássio, cálcio e magnésio em solução nutritiva no crescimento e composição da soja (Glycine max), observou que a concentração de magnésio na massa seca das folhas superiores e nos caules decresceu de 0,61 a $0,49 \%$ e de 0,47 a $0,32 \%$, respectivamente, com o aumento das doses de potássio de 117 a $351 \mathrm{mg} \mathrm{L}^{-1}$ na solução. Porém, os tratamentos utilizados não influenciaram na altura das plantas e na produção de massa seca.

Para observar a flutuação sazonal dos teores médios de potássio e magnésio no solo e concentrações nas plantas de três áreas de campo natural, Alfaya et al. (1998) realizaram experimento e verificaram que as concentrações dos nutrientes estudados no solo foram suficientes para a produção da pastagem, e nas plantas foram capazes de suprir as exigências nutricionais de bovinos em todas as épocas e áreas.

Monteiro et al. (1998), estudando os nutrientes magnésio, cálcio e potássio no tecido foliar de Brachiaria decumbens submetida a doses de magnésio, obtiveram que a concentração do magnésio nos tecidos foliares 
analisados foi aumentando de acordo com o incremento da concentração do nutriente na solução nutritiva. Entretanto a concentração de potássio no tecido decresceu com a elevação no suprimento de magnésio.

Avaliando o efeito da adubação potássica $\left(0 ; 15 ; 30\right.$ e $\left.60 \mathrm{mg} \mathrm{dm}^{-3}\right)$ na produção de massa seca da Brachiaria brizantha cv. Marandu e do Stylosanthes guianensis em vários estádios de crescimento e na absorção de potássio, cálcio e magnésio, Rodrigues \& Rossiello (1995) detectaram que o incremento nas doses de potássio fez reduzir significativamente o acúmulo total de magnésio nas plantas.

Em solos de Porto Rico, Vicente-Chandler et al. (1962), estudando o efeito da fertilização potássica $\left(0,200,400\right.$ e $\left.1600 \mathrm{Kg} \mathrm{ha}^{-1}\right)$ nas gramíneas Panicum maximum, Pennisetum purpureum, Panicum barbinode e Digitaria decumbens constataram reduções nas concentrações de cálcio e fósforo das forragens, enquanto a concentração de magnésio diminuiu mais nitidamente com o aumento das doses de potássio. Para o Panicum maximum, Pennisetum purpureum, Panicum barbinode e Digitaria decumbens essa redução na concentração de magnésio entre a menor e a maior dose de potássio foi de 55 a $41 \%$; de 50 a $22 \%$; de 32 a $25 \%$ e de 24 a $22 \%$, respectivamente.

Dejou \& Montard (1982) conduziram um experimento durante cinco anos para verificar os efeitos da adubação com potássio e com magnésio para a cultura de gramínea. Observaram um acentuado antagonismo entre magnésio e potássio, de tal forma que a resposta positiva da adubação com magnésio foi anulada em presença de potássio na adubação.

A concentração de magnésio nas partes da Brachiaria decumbens submetida a doses de potássio foi estudada por Mattos \& Monteiro (1998a). Revelaram que há de se atentar para a nutrição dessa planta com relação ao magnésio quando o potássio for colocado em alta disponibilidade. 


\subsection{Perfilhamento}

O perfilho de gramíneas forrageiras é a unidade primária de crescimento, de tal forma que uma pastagem pode ser considerada como uma população de perfilhos (Korte, 1986). Assim, aumentos de produção de forragem podem ser atribuídos ao crescimento em densidade populacional, de massa por perfilho ou de uma combinação de ambos (Nelson \& Zarrough, 1981).

Langer (1963) citou que a capacidade de perfilhamento das gramíneas forrageiras depende de muitos fatores, entre os quais destacam-se as características genéticas de cada espécie e o seu estado nutricional. Para Gomide (1997) o perfilhamento responde positivamente à disponibilidade de nutrientes no solo.

No início do estabelecimento de uma gramínea, o perfilhamento da planta inicia-se primeiramente através de gemas basilares (Langer, 1963). Cada folha tem em sua axila uma gema que, dependendo das condições do meio, pode-se desenvolver dando origem a um novo perfilho (Gomide, 1997). Sendo assim, Skinner \& Nelson (1994) relataram que a diferença na taxa de aparecimento de folhas afeta o número de aparecimento de perfilhos por planta.

O número e o tamanho dos perfilhos podem, dentro de limites, compensar o efeito de densidade de plantas, sendo ambos aspectos que influenciam a produtividade de uma pastagem (Langer, 1974). Ainda Langer (1963) ressaltou que em plantas cultivadas com maior espaçamento, quando os perfilhos reprodutivos não são eliminados, o efeito do corte é pequeno. Porém, em condições de cultivo denso, o corte estimula o perfilhamento mesmo sem a remoção das gemas apicais, uma vez que seu maior efeito é devido ao aumento da intensidade luminosa que alcança as gemas basais. A produção de novos perfilhos é normalmente um processo intermitente que pode ser disparado pela desfolha das plantas e, consequentemente, pela melhoria da iluminação na base da pastagem (Hodgson, 1990). 
Loch (1985) mostrou que o máximo de perfilhamento ocorre durante a fase inicial do crescimento vegetativo, pois o estudo de crescimento contínuo de gramíneas tropicais revelou que o número de perfilhos decresceu com o avanço da idade da planta. Essa queda é devida à competição por luz entre perfilhos (Andrade, 1987). Também, Corsi (1984) determinou que a espécie Panicum maximum cultivar '68s-5-2' apresentou o máximo de pefilhamento até o $8^{\circ}$ dia após o corte, tendo sido insignificante o número de perfilhos após o 16ํㅡㄹ dia.

Gomide et al. (1979), estudando os fatores morfofisiológicos de rebrota do capim-Colonião em várias épocas, constataram que o número de perfilhos por touceira não mostrou acentuada variação no decorrer do experimento, mas apenas tendência de diminuição no decorrer de cada crescimento. Isso evidenciou que houve a substituição de perfilhos velhos por novos e que o maior vigor na rebrota ocorreu após os dois primeiros cortes. Nascimento et al. (1980) também observaram aumento no perfilhamento após o corte em estudo com os capins Colonião (Panicum maximum), Jaraguá (Hyparrhenia rufa) e Gordura (Melinis minutiflora) .

Para Briske (1986) o perfilhamento representa um importante fenômeno em gramíneas forrageiras, pois garante sua perenidade após decapitação dos perfilhos pelo corte ou pastejo. Barbosa et al. (1996) concluíram, para cultivares de Panicum maximum (Tobiatã, Tanzânia, Mombaça e Colonião), que o perfilhamento após o corte respondeu positivamente à decapitação de perfilhos. Houve maior resposta para perfilhos aéreos em relação aos basais em função da eliminação do meristema apical, e a dinâmica de perfilhamento foi variável entre as estações de crescimento. Esses resultados não variaram significativamente entre os cultivares avaliados.

Herling et al. (1991), estudando a influência de doses de adubos nitrogenados e potássicos na produção de perfilhos em capim-Setária, verificaram que o número de perfilhos basilares (rebrota) foi maior em idades mais avançadas e com o aumento da adubação nitrogenada. Porém, foi constatado que ao dobrar a dose de nitrogênio de 80 para $160 \mathrm{~kg} \mathrm{ha}^{-1}$, o nível 
de resposta foi inferior ao esperado e que a adubação potássica não mostrou efeitos significativos no aparecimento de perfilhos.

Nabinger (1997) relatou resultados positivos do nitrogênio na taxa de aparecimento de perfilhos. Contudo, alta disponibilidade desse nutriente pode determinar uma menor densidade de perfilhos na pastagem devido ao mais rápido desenvolvimento do índice de área foliar e ao aumento na mortalidade de perfilhos. Destacou ainda que o nitrogênio é o nutriente mais importante para o perfilhamento de gramíneas estabelecidas, visto que, em condições de deficiência desse nutriente, o número de perfilhos na planta é significativamente reduzido.

Ferrari Neto (1991), avaliando as limitações nutricionais do Panicum maximum cv. Colonião e Brachiaria decumbens por meio da técnica da diagnose por subtração observou que o perfilhamento das espécies foi alterado, em ordem decrescente, pelas omissões de fósforo, nitrogênio, enxofre e potássio. Esses resultados corroboram o estudo de Monteiro et al. (1995), que também apontaram o fósforo como o nutriente mais limitante para o número de perfilhos na fase de estabelecimento de Brachiaria brizantha cv. Marandu.

Corrêa \& Monteiro (1997), em experimento com doses de nitrogênio (42; 210 e $378 \mathrm{mg} \mathrm{L}^{-1}$ ) e magnésio (4,8 e $48 \mathrm{mg} \mathrm{L}^{-1}$ ) em capins Colonião, Tanzânia-1 e Vencedor, encontraram efeitos significativos das doses de nitrogênio no número de perfilhos, tanto no primeiro como no segundo período de crescimento desses capins. Entretanto, não ocorreu influência significativa das doses de magnésio no perfilhamento.

Avaliando a fisiologia de perfihamento do capim-Mombaça sob pastejo, Herling et al. (1998) mostraram que não foram observadas grandes variações na densidade de perfilhos no decorrer das avaliações. A decapitação dos meristemas apicais foi baixa, porém crescente no decorrer dos pastejos.

Carvalho et al. (1999), em trabalho com os cultivares de Panicum maximum (Aruana, Mombaça e Tanzânia) submetidos a dois níveis de desfolha avaliaram a dinâmica do perfilhamento e observaram que em cortes baixos a 
taxa de perfilhamento evidenciou um aumento inicial, seguido de uma taxa de mortalidade de perfilho que conduzia à redução do número de perfilhos no último corte, em todos os cultivares. No corte alto houve aumento do número de perfilhos nos cultivares Tanzânia e Mombaça.

Avaliando as características do perfilhamento na rebrota de quatro cultivares de Panicum (Mombaça, Tanzânia, Colonião e Tobiatã) submetidos a duas alturas de cortes, Coelho et al. (1999) concluiram que o cultivar Tanzânia apresentou maior número médio de perfilhos, porém o cultivar Tobiatã mostrou maior capacidade de emitir perfilhos e que a altura de corte não influenciou o aparecimento de perfilhos nos cultivares avaliados.

\section{8 Área foliar}

No crescimento da lâmina foliar em gramíneas, a lâmina é gerada a partir de filas de células formadas em uma zona meristemática, que se desenvolve na base do primórdio foliar. Quando uma folha emerge na base das folhas mais velhas, a porção visível está totalmente expandida e atinge rapidamente a máxima capacidade fotossintética. Dessa forma, uma folha em crescimento mostra todos os estádios de desenvolvimento, do mais imaturo no meristema ao totalmente diferenciado e funcional na ponta (Dale, 1992).

Para Humphries \& Wheeler (1963) o tamanho final de uma folha é determinado pelo número de células primordiais, taxa de divisão celular, duração da fase de divisão celular e tamanho das células maduras, e isso varia conforme a planta e o estado de nutrição dela.

Numa pastagem em crescimento vegetativo na qual aparentemente apenas folhas são produzidas (pois ainda não há alongamento dos entrenós) a morfogênese pode ser descrita por três características básicas: taxa de surgimento de folhas, taxa de alongamento das folhas e duração de vida da folha (Chapman \& Lemaire, 1993). Para Thomas \& Stoddart (1980) o 
aparecimento, o crescimento e a morte das folhas em uma planta dependem de fatores genéticos (espécie e variedades) e do meio (temperatura, umidade, fotoperíodo, intensidade luminosa, nutrição mineral, presença de patógenos, entre outros).

Em seus estudos, Watson (1952) afirmou ser fato conhecido que a área foliar das plantas é dependente da nutrição da mesma, embora não tenha analisado a maneira pela qual os aspectos do crescimento da folha são influenciados pelo suprimento de nutrientes minerais. Lopes et al. (1982) relataram a importância da área foliar para a produtividade de uma cultura.

A taxa de alongamento de folhas é um parâmetro morfológico de extrema importância para a avaliação de gramíneas, devido a sua forte correlação com a produtividade da planta forrageira (Hay \& Walker, 1989). Gastal et al. (1992) ressaltaram que a disponibilidade de nitrogênio tem pronunciado efeito na taxa de alongamento das folhas por perfilho, podendo resultar em um determinado dia de avaliação valores de três a quatro vezes menores num alto nível de deficiência, quando comparado a um nível não limitante desse nutriente.

Dentre os fatores limitantes ao índice de área foliar (IAF) a deficiência de nitrogênio e de água são considerados de maior importância. Tanto a deficiência de nitrogênio como de água diminuem progressivamente a taxa fotossintética das folhas, a interceptação da luz, a produção de biomassa e o índice de área foliar (Nabinger, 1997).

Pearse \& Wilman (1984), estudando o efeito da freqüência de corte e de doses de nitrogênio no alongamento das folhas de azevém-perene (Lolium perenne), observaram que à medida em que os intervalos entre cortes aumentaram (um, dois, três e seis semanas), a taxa de alongamento de folhas sofreu acréscimos $(6,7 ; 7,8 ; 9,0$ e 9,3 mm/dia). Por outro lado, a aplicação de nitrogênio $\left(0 ; 66\right.$ e $\left.132 \mathrm{~kg} \mathrm{ha}^{-1}\right)$ resultou em aumento na taxa de alongamento $(4,2 ; 8,3$ e $12,1 \mathrm{~mm} / \mathrm{dia}$, respectivamente). 
Para Santos, P. (1997) a necessidade de nutrir adequadamente uma planta para que ela cresça e se desenvolva é conhecida e aceita há muito tempo, porém muitos mecanismos desse processo ainda precisam ser elucidados. Ingestad (1981), verificando a nutrição e crescimento de bétula (Betula verrugosa), encontrou relações lineares entre qualquer combinação de duas das seguintes variáveis: taxa relativa de adição de nutrientes, taxa de crescimento relativo e concentração de nutrientes nas plantas.

Meiri et al. (1992), avaliando o crescimento e a deposição de nutrientes em folhas de milho, observou que os elementos potássio, cloro, cálcio, magnésio e fósforo mostraram variados padrões de distribuição em termos de densidade iônica nas folhas. O potássio e o cloro apresentaram densidades mínimas nas pontas das folhas, sendo que a densidade do potássio foi máxima na região de crescimento das folhas. Cálcio, magnésio e fósforo apresentaram densidades relativamente maiores na base da zona de alongamento e nas extremidades das folhas. Na base da zona de alongamento, o fósforo e o magnésio apresentaram maiores densidades nas lâminas de folhas recém-expandidas, enquanto nas lâminas de folhas maduras o cálcio apresentou maior densidade. A taxa de deposição de todos os nutrientes foi maior na região de máximo alongamento das folhas.

A carência de resultados envolvendo a avaliação do crescimento de folhas em plantas forrageiras em função do suprimento de potássio e de magnésio, é um fato marcante na literatura. Entretanto, diversos resultados com adubação nitrogenada, avaliando expansão foliar em monocotiledôneas e dicotiledôneas estão disponíveis.

\subsection{Estimativa do teor de clorofila pelo valor SPAD}

Desenvolvido pela Companhia Minolta no Japão, o aparelho portátil Chlorophyll Meter SPAD-502 (Soil and Plant Analysis Development) permite a 
avaliação indireta do teor de clorofila nas plantas. Esse aparelho recebeu no Brasil o nome de clorofilômetro e expressa os resultados em valor de unidades SPAD. Por ser portátil e de fácil manuseio, esse aparelho é usado diretamente no campo e fornece resultados imediatos da estimativa do teor de clorofila através de leituras realizadas no limbo foliar (Minolta Camera Corporation, 1989)

O medidor de clorofila SPAD-502 fornece leituras que correspondem ao teor do pigmento presente na folha. Os valores são calculados com base na quantidade de luz transmitida pela folha em duas regiões de comprimento de onda nas quais a absorção pela clorofila é diferente. $O$ instrumento tem sido usado para estimar a concentração de nitrogênio da folha, visto que o teor de clorofila se relaciona positivamente com a concentração desse nutriente (Malavolta et al., 1997).

Um dos métodos utilizados em laboratório para a determinação de clorofila é descrito por Arnon (1949). Porém esse método ainda que fácil apresenta desvantagens como coleta destrutiva do material vegetal e extração via maceração com acetona. Com o advento de medidores portáteis a estimativa do teor de clorofila tornourse fácil e rápida, sendo realizada diretamente no campo (Yadava, 1986).

O SPAD-502 tem sido utilizado com sucesso para diagnosticar a concentração de nitrogênio em culturas como milho (Piekielek \& Fox, 1992; Blackmer et al., 1994), batata (Minotti et al., 1994), trigo (Hoel \& Solhaug, 1998), tomate (Guimarães et al., 1999), maçã (Neilsen et al., 1995), entre outras.

Fox et al. (1994) buscaram determinar a necessidade de adubação nitrogenada complementar através de avaliação da correlação entre a concentração de nitrogênio em folhas do trigo (Triticium aestivum) de inverno e a estimativa do teor de clorofila utilizando o aparelho SPAD-502. Constataram que o nível crítico foi de 46 unidades SPAD e que os resultados do uso do clorofilômetro foram corretos para predizer as doses de fertilizantes nitrogenados necessárias para obtenção da máxima colheita econômica. 
Avaliando os efeitos de doses de nitrogênio e fósforo na leitura SPAD, nas folhas de quatro cultivares de Panicum maximum (Aruana, Tanzânia, Tobiatã e Vencedor), Paulino et al. (1998) concluíram que essa leitura pode identificar prontamente severas deficiências de nitrogênio em Panicum maximum em condições de campo e que os teores de clorofila correspondentes a menos de 38 unidades de SPAD são indicativos de estado nutricional inadequado.

Estudando a relação entre leitura SPAD e teor de clorofila total em folhas de maçã (Malus domestica), Campbell et al. (1990) encontraram valores diferenciados em função da época (inverno e verão) e principalmente entre as condições de cultivo (campo e casa-de-vegetação). No inverno os valores de SPAD variaram de 43 a 53 unidades, enquanto no verão estes valores foram superiores ficando na faixa de 46 a 58 unidades. O valor SPAD em campo variou de 42 a 64 no primeiro ano e de 52 a 67 unidades no segundo ano, enquanto em casa-de-vegetação os resultados variaram de 36 a 64 e de 34 a 55 unidades no primeiro e segundo anos, respectivamente.

Santos, A. (1997) avaliando em casa-de-vegetação os efeitos de nitrogênio e de enxofre no teor estimado de clorofila em Brachiaria decumbens cv. Basilisk, observou que o teor de clorofila na planta forrageira variou entre 17,0 no primeiro crescimento e 23,9 unidades no segundo crescimento para a condição de omissão de nitrogênio e de 50,2 e 52,0 unidades para as doses de nitrogênio de 330 e $442 \mathrm{mg} \mathrm{L}^{-1}$, respectivamente. Para o estudo com enxofre, o valor SPAD máximo esteve em 43,1 unidades no primeiro crescimento e em 38,0 unidades de valor SPAD no segundo crescimento.

Avaliando os valores SPAD obtidos nas lâminas das folhas dos capins Aruana e Mombaça adubados com nitrogênio, Colozza (1998) observou que a aplicação das doses de nitrogênio proporcionou aumentos na estimativa do teor de clorofila nas folhas desses cultivares de Panicum maximum. Para o cultivar Aruana os valores de leitura SPAD, no primeiro corte, estiveram entre 20,6 e 38,2 unidades para lâminas de folhas emergentes; de 23,6 e 39,7 unidades nas 
lâminas de folhas recém-expandidas e entre 17,8 e 38,0 unidades; para as lâminas de folhas maduras. Entretanto, para o segundo corte esses valores variaram de 13,4 a 35,3 unidades nas folhas emergentes; de 16,0 a 43,2 unidades em lâminas de folhas recém-expandidas e de 15,2 a 39,7 unidades de valor SPAD para as lâminas de folhas maduras. No cultivar Mombaça, no primeiro corte, os valores máximos de SPAD foram respectivamente de 35,6; 45,0 e 39,6 em leitura nas folhas emergentes, nas lâminas de folhas recémexpandidas e nas lâminas de folhas maduras. No segundo crescimento desse capim os valores foram de 34,3; 40,6 e 37,4 nas folhas emergentes, nas lâminas de folhas recém-expandidas e nas lâminas de folhas maduras, respectivamente.

Os resultados encontrados por Peng et al. (1995) com a cultura do arroz (Oryza sativa) confirmam que o clorofilômetro é eficaz na diagnose da concentração de nitrogênio em função da idade da planta. Esses autores obtiveram leituras que variaram entre 35 a 63 unidades de valor SPAD. Hoel \& Solhaug (1998) relataram que a estimativa do teor de clorofila através do SPAD pode ser usado como indicador do nitrogênio contido na folha.

Almeida (1998), combinando doses de fósforo e de magnésio para nutrição e produção de duas espécies de braquiária, verificou que os valores em unidades de SPAD avaliados em três épocas ( 25 e 35 dias após transplante e 10 dias após o primeiro corte) mostraram significância para a interação entre as doses desses dois nutrientes apenas na primeira época. Nas demais avaliações somente as doses de fósforo mostraram resultados significativos.

Comparando a utilização de métodos convencionais empregados em laboratório para determinar o teor de clorofila no tecido da folha e medidas de leituras obtidas pelo clorofilômetro, Yadava (1986) verificou alta correlação entre a leitura SPAD e a concentração de clorofila em 40 folhas amostradas em 22 espécies representando 14 famílias de plantas. As unidades SPAD variaram de 8,3 a 51,8 . 
Turner \& Jund (1991), em experimento com três tipos de solos do Texas-EUA, verificaram a necessidade de adubação nitrogenada complementar para a cultura do arroz por meio de leituras SPAD e encontraram que o nível crítico correspondeu a 42 unidades SPAD.

A carência de trabalhos relacionando a estimativa do teor de clorofila obtidas através do SPAD em lâmina foliar de gramíneas forrageiras em função de doses de magnésio e potássio é fato relevante. A grande maioria dos trabalhos de pesquisa envolvendo este assunto refere-se ao nitrogênio.

\subsection{Nível crítico e sintomatologia de deficiência de potássio e magnésio}

Um dos métodos utilizados para se avaliar o estado nutricional de uma planta é pela análise foliar, pois a folha é o órgão da planta que melhor reflete 0 seu estado nutricional Ureta (1991). Segundo o autor, existe um nível crítico para cada nutriente, e que acima deste nível um aumento do nutriente pode traduzir-se em aumento de produção, mas abaixo dele a planta pode estar em condições de deficiência nutricional.

Malavolta (1980) conceituou nível critico como sendo a concentração abaixo da qual a produção é limitada ou indica deficiência. Ulrich (1976) definiu nível crítico como uma faixa de concentração, acima da qual a planta está suprida adequadamente do nutriente e abaixo da mesma a planta apresenta-se deficiente.

Vicente-Chandler et al. (1962), estudando a fertilização potássica em gramíneas, observaram que as mais elevadas produções das plantas forrageiras estavam associadas à concentração de potássio de 15 a $20 \mathrm{~g} \mathrm{~kg}^{-1}$, na parte aérea das plantas colhidas aos 60 dias após a emergência.

Utilizando a diagnose por subtração, Carriel et al. (1989) obtiveram em adubação completa valores de nível crítico de potássio de $11,0 \mathrm{~g} \mathrm{~kg}^{-1}$ no primeiro corte e $13 \mathrm{~g} \mathrm{~kg}^{-1}$ no segundo corte, em capim-Colonião. Para a 
Brachiaria decumbens o nível crítico de potássio foi de 10,5 e $8,2 \mathrm{~g} \mathrm{~kg}^{-1}$ no primeiro e segundo cortes, respectivamente.

Mattos (1997) verificou que o nível critico de potássio, para $90 \%$ da produção máxima, em Brachiaria brizantha cv. Marandu, foi de 29 e de $30 \mathrm{~g} \mathrm{~kg}^{-1}$ no primeiro e segundo cortes, respectivamente. Para a Brachiaria decumbens cv. Basilisk, o nível crítico de potássio nas lâminas de folhas recém-expandidas foi de $23 \mathrm{~g} \mathrm{~kg}^{-1}$ no primeiro corte e de $20 \mathrm{~g} \mathrm{~kg}^{-1}$, para 0 segundo corte. Por outro lado, CIAT (1982), na Colômbia, apresentou relato com Brachiaria decumbens, cultivada em oito semanas na estação chuvosa, com o nível crítico de potássio de $8,3 \mathrm{~g} \mathrm{~kg}^{-1}$ associado a $80 \%$ da produção máxima.

Os níveis críticos de potássio na parte aérea do capim-Colonião encontrados por Faquin et al. (1995), correspondentes a $80 \%$ e $90 \%$ da produção máxima foram, respectivamente, de 31,0 e $34,9 \mathrm{~g} \mathrm{~kg}^{-1}$ no primeiro crescimento e de 7,8 e 9,5 $\mathrm{g} \mathrm{kg}^{-1}$ no segundo crescimento. Para Hoffmann et al. (1992) a faixa crítica da concentração de potássio para a obtenção de $80 \%$ e $90 \%$ da produção máxima do capim-Colonião foi de 12,1 e $14,6 \mathrm{~g} \mathrm{~kg}^{-1}$, respectivamente.

Toledo (1986) considerou que o nível adequado de magnésio éde $2,0 \mathrm{~g} \mathrm{~kg}^{-1}$ para atender as exigências nutricionais do capim-Colonião. Porém, Mayland \& Grunes (1979), relataram que concentrações inferiores a 2,0 $\mathrm{g} \mathrm{kg}^{-1}$ de magnésio na massa seca e mais elevadas que $3,0 \mathrm{~g} \mathrm{~kg}^{-1}$ de potássio, ou ainda uma relação $\mathrm{K} /(\mathrm{Ca}+\mathrm{Mg})$ maior que $2,2 \mathrm{~g} \mathrm{~kg}^{-1} \mathrm{em}$ plantas forrageiras pode estar associadas com o distúrbio conhecido por tetania das pastagens.

A falta ou o excesso de um dado nutriente provoca sempre a manifestação visível de anormalidades qualquer que seja a espécie considerada, visto que as funções exercidas na fisiologia da planta são sempre as mesmas. A manifestação externa de uma carência ou excesso tóxico pode ser concebida como último passo de uma seqüência de eventos (Malavolta, 1980). 
De acordo com relato de Werner (1983), os capins deficientes em potássio apresentam colmos finos, raquíticos e pouco resistentes ao tombamento. As folhas são pouco desenvolvidas, com coloração normal e ligeiramente cloróticas quando mais novas e amarelo-alaranjadas (típico em capim-Colonião) ou amareladas quando tornam-se intermediárias. As folhas começam a mostrar manchas necróticas, que aparecem em maior número nas pontas e ao longo das margens, permanecendo as partes centrais da folha verdes por algum tempo. Ao envelhecer, essas folhas começam a secar da ponta para a base, sendo a necrose mais intensa nas margens. Depois de secas, essas folhas ficam com uma coloração parda, conservando as manchas necróticas de tonalidade mais escura em fundo pardo. Pastagens de capins com esses sintomas causam a impressão de terem sido "sapecadas" pelo fogo.

Sintomas visuais característicos de deficiência de potássio, como os descritos por Werner (1983), foram observados em Panicum maximum por Andrade et al. (1996) quando o nutriente estava com teor no solo de $0,9 \mathrm{mmol}_{\mathrm{c}} \mathrm{dm}^{-3}$.

Mattos (1997) detectou os primeiros sintomas de deficiência de potássio em Brachiaria decumbens aos 15 dias após transplante, na condição de não suprimento de potássio. Os sintomas eram de clorose ra borda das folhas, que se acentuavam em direção ànervura principal, em forma de um "V" invertido. Para a Brachiaria brizantha cv. Marandu os sintomas visuais foram similares, mas apareceram aos 10 dias após transplante das mudas.

Verificando a resposta de Brachiaria decumbens à fertilização com nitrogênio e potássio em um Latossolo Vermelho Amarelo álico, Carvalho et al. (1991) constataram que com baixo teor de potássio no solo, desenvolveram-se sintomas visuais de deficiência do nutriente nas folhas. Porém, esses sintomas desapareceram quando as concentrações médias de potássio na forragem situaram-se entre 10 a $15 \mathrm{~g} \mathrm{~kg}^{-1}$. 
Segundo Malavolta et al. (1997) os sintomas visuais da deficiência de magnésio se caracterizam por uma clorose internerval nas folhas, usualmente começando e sendo mais severa nas lâminas de folhas maduras.

Rao et al. (1996) relataram que a deficiência de magnésio em lâminas de folhas maduras do capim-Braquiária se manifestou como clorose internerval acompanhada de uma coloração arroxeada nas extremidades. Também em capim-Braquiária, Sarkis et al. (1996) observaram que as plantas crescidas em solução sem suprimento de magnésio exibiam claramente o sintoma de clorose internerval nas lâminas de folhas maduras.

Em experimento com omissão de nutrientes no capim-Colonião, Werner \& Haag (1972) constataram que as plantas desenvolvidas em omissão de magnésio foram as últimas a apresentarem sintomas visuais de deficiência quando comparado aos demais tratamentos, e que os mesmos eram bem definidos. As lâminas de folhas recém-expandidas e maduras apresentaram uma coloração verde mais amarelada que as do tratamento completo, bem como tinham estrias rugosas longitudinais que davam um aspecto de transparência æ̀s folhas. 


\section{MATERIAL E MÉTODOS}

\subsection{Espécie vegetal}

A espécie em estudo está classificada na divisão Angiosperma; classe Monocotiledoneae; ordem: Graminales; família: Gramineae; subfamília: Panicoideae; tribo: Paniceae; gênero: Panicum; espécie: Panicum maximum Jacq. cultivar Mombaça (Mitidieri, 1983 e Jank,1995)

\subsection{Local dos experimentos}

O presente estudo consistiu de dois experimentos independentes, o primeiro com oito doses de potássio e o segundo com oito doses de magnésio, e foram conduzidos em casa-de-vegetação localizada no Departamento de Solos e Nutrição de Plantas, da Escola Superior de Agricultura "Luiz de Queiroz" - USP, Campus de Piracicaba, Estado de São Paulo.

\subsection{Delineamento experimental}

O esquema experimental foi de blocos completos ao acaso, com oito doses de cada nutriente e quatro repetições. Para garantir a obtenção de material necessário para as determinações químicas nos componentes da parte aérea das plantas (folhas emergentes, lâminas de folhas 
recém-expandidas, lâminas de folhas maduras e colmos+bainhas) e das raízes, os vasos foram duplicados no experimento, o que resultou em 64 vasos em cada experimento.

\subsection{Instalação e condução dos experimentos}

As sementes do capim-Mombaça, foram germinadas em bandejas plásticas, contendo areia lavada em água corrente e em água destilada. $\mathrm{O}$ transplantio foi realizado quando as plântulas estavam com altura aproximada de cinco centímetros.

Foram utilizados vasos com capacidade de 3,6 litros contendo sílica como substrato, a qual apresentava granulometria de aproximadamente $3 \mathrm{~mm}$ de diâmetro e estava livre de impurezas (após múltiplas lavagens).

Para cada vaso foram transplantadas 15 mudas e durante os três dias subsequentes, cada vaso recebeu um litro de solução com $30 \%$ da concentração correspondente a cada dose em estudo. Desbastes foram realizados até que permanecessem cinco plantas por vaso, quando a solução com concentração definitiva foi adicionada aos vasos e essa solução foi trocada a cada 10 dias. As soluções foram circuladas três vezes ao dia para que houvesse aeração das mesmas e a solução de cada vaso foi drenada à noite para um litro receptor. $O$ volume de cada litro foi completado diariamente com água deionizada, pela manhã, antes de ser adicionado no seu respectivo vaso.

Durante o período do experimento, a cada dois dias os vasos foram remanejados dentro de cada bloco para que houvesse menor efeito das condições ambientais. 


\subsection{Experimento com doses de potássio}

Foram utilizadas oito doses de potássio correspondentes a: 0; 9,75; 39; 78; 156; 234; 312 e $468 \mathrm{mg} \mathrm{L}^{-1}$. As soluções nutritivas foram preparadas a partir daquela de Sarruge (1975), com modificações para as doses desejadas de potássio. As soluções foram preparadas como demonstrado na Tabela 1.

No experimento com doses de potássio cultivou-se o Panicum maximum cv. Mombaça no período de janeiro a março de 1999, com temperatura ambiente na casa-de-vegetação variando de 22 a $42^{\circ} \mathrm{C}$.

Tabela 1. Volumes das soluções estoque empregados no preparo das soluções nutritivas para as doses estudadas de potássio.

\begin{tabular}{lccccccccc}
\hline \multicolumn{1}{l}{$\begin{array}{l}\text { Soluções } \\
\text { estoque }\left(\mathrm{mol} \mathrm{L}^{-1}\right)\end{array}$} & 0 & 9,75 & 39 & 78 & 156 & 234 & 312 & 468 \\
\hline $\mathrm{KH}_{2} \mathrm{PO}_{4}$ & 1 & - & - & 1 & 1 & 1 & 1 & 1 & 1 \\
$\mathrm{KNO}_{3}$ & 1 & - & - & - & 1 & 3 & 5 & - & - \\
$\mathrm{Ca}\left(\mathrm{NO}_{3}\right)_{2}$ & 1 & 5 & 5 & 5 & 5 & 5 & 5 & 5 & 5 \\
$\mathrm{MgSO}_{4}$ & 1 & 2 & 2 & 2 & 2 & 2 & 2 & 2 & 2 \\
$\mathrm{NH}_{4} \mathrm{H}_{2} \mathrm{PO}_{4}$ & 1 & 1 & 1 & - & - & - & - & - & - \\
$\mathrm{NH}_{4} \mathrm{NO}_{3}$ & 1 & 2 & 2 & 2,5 & 2 & 1 & - & 2,5 & 2,5 \\
$\mathrm{KCl}$ & 1 & - & 0,25 & - & - & - & - & 7 & 11 \\
$\mathrm{Micro}-\mathrm{Fe}^{*}$ & - & 1 & 1 & 1 & 1 & 1 & 1 & 1 & 1 \\
$\mathrm{Fe}_{-} \mathrm{EDTA}^{* *}$ & - & 1 & 1 & 1 & 1 & 1 & 1 & 1 & 1 \\
\hline
\end{tabular}

* A solução de micronutrientes teve a seguinte composição $\left(\mathrm{g} \mathrm{L}^{-1}\right): \mathrm{H}_{\mathrm{B}} \mathrm{BO}_{3}=2,86$; $\mathrm{MnCl}_{2} \cdot 4 \mathrm{H}_{2} \mathrm{O}=1,81 ; \mathrm{ZnCl}_{2}=0,10 ; \mathrm{CuCl}_{2}=0,04 \mathrm{e} \mathrm{H}_{2} \mathrm{MoO}_{4} \cdot \mathrm{H}_{2} \mathrm{O}=0,02$.

** Dissolveram-se 26,1 g de EDTA dissódico em $286 \mathrm{ml}$ de $\mathrm{NaOH} 1 \mathrm{~mol} \mathrm{~L}^{-1}$ misturando-se com $24,0 \mathrm{~g}$ de $\mathrm{FeSO}_{4} \cdot 7 \mathrm{H}_{2} \mathrm{O}$, arejando-se por uma noite e completando-se a $1 \mathrm{~L}$ com água desmineralizada.

Aos 30 dias após o transplante realizoutse o primeiro corte das plantas a uma altura de cinco centimetros do colo das plantas e coletou-se a parte aérea que foi separada em: a) folhas emergentes (FE) : folhas do topo da planta, sem lígula visível; b) lâminas de folhas recém-expandidas (LN): lâminas das duas folhas mais novas completamente expandidas, com lígula 
visível; c) lâminas de folhas maduras (LM): lâminas das demais folhas completamente expandidas, com lígula visível; d) colmos mais bainhas (CB): colmos mais as bainhas que foram mantidas a eles circundadas. A separação dos quatro componentes da parte aérea das plantas se deu de forma idêntica a adotada por Mattos (1997), Santos, A. (1997), Ferragine (1998) e Benetti \& Monteiro (1999) com diferenças somente nas denominações desses componentes (já que as expressões de folhas não-expandidas, folhas novas, folhas velhas e colmos+bainhas foram adotadas naqueles estudos).

Aos 22 dias após o primeiro corte realizou-se a segunda colheita, separando-se a parte aérea pelo mesmo critério adotado no primeiro corte, coletando-se também as raízes que foram retiradas da sílica e lavadas em água corrente e destilada.

Todo o material foi colocado para secar em estufa de circulação forçada de ar à temperatura de $70^{\circ} \mathrm{C}$, até peso constante. As amostras foram moídas em moinho tipo Wiley e acondicionadas em sacos plásticos.

\subsection{Experimento com doses de magnésio}

Foram utilizadas oito doses de magnésio correspondentes a: 0; 1,2; 3,$6 ; 12 ; 24 ; 36 ; 48$ e $60 \mathrm{mg} \mathrm{L}^{-1}$. As soluções nutritivas foram preparadas a partir da proposta por Sarruge (1975), devidamente modificada para as doses de magnésio. A forma de preparo das soluções para as oito doses de magnésio é mostrada na Tabela 2.

Neste experimento cultivourse o Panicum maximum cv. Mombaça no período de janeiro a março de 2000 , com temperatura na casa-de-vegetação variando de 22 a $43^{\circ} \mathrm{C}$.

Aos 29 dias após o transplante procedeurse o primeiro corte e a segunda colheita ocorreu aos 21 dias após o primeiro corte. Os critérios e 
procedimentos adotados em ambos os cortes foram os mesmos utilizados no experimento com doses de potássio.

Tabela 2. Volumes das soluções estoque empregados no preparo das soluções nutritivas para as doses estudadas de magnésio.

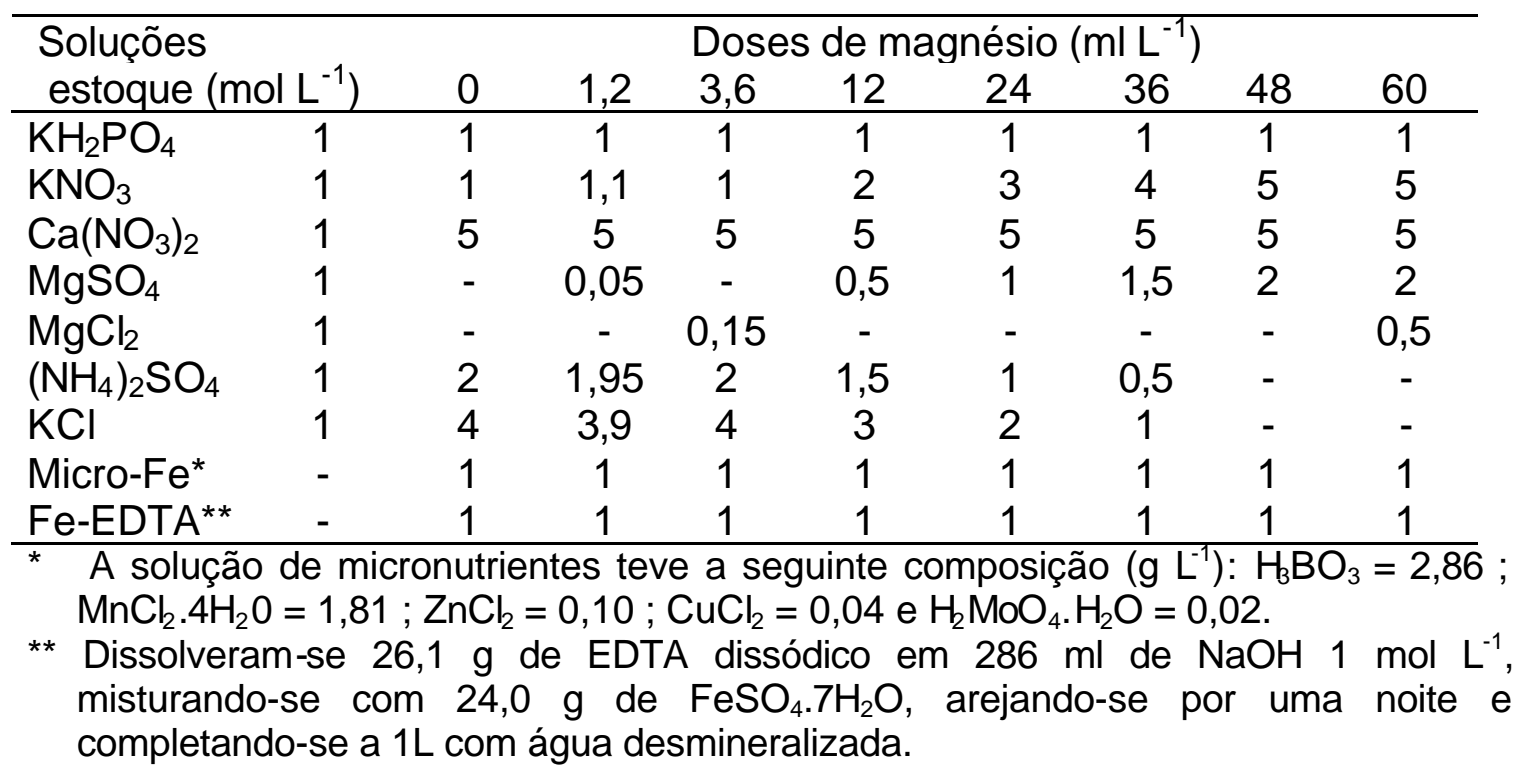

\subsection{Perfilhamento}

Quando os perfilhos começaram a surgir na base do colmo foi iniciada a marcação dos perfilhos nas cinco plantas de cada vaso. Foram colocados nos perfilhos anéis confeccionados de fio de metal encapado com material plástico colorido (Figura 1). A cor do anel utilizado era mudada para cada data de marcação dos perfilhos. A cada dois dias foram anelados todos os perfilhos que emergiram e, portanto, que foram encontrados sem identificação, de maneira que na oportunidade dos cortes foi possível a obtenção do número total de perfilhos por vaso. O colmo principal (planta-mãe) também foi incluído na contagem dos perfilhos. 
Após o primeiro corte das plantas foram utilizadas duas cores de anéis para marcação dos perfilhos, sendo uma para marcar os provenientes da rebrota e outra para marcar os novos.

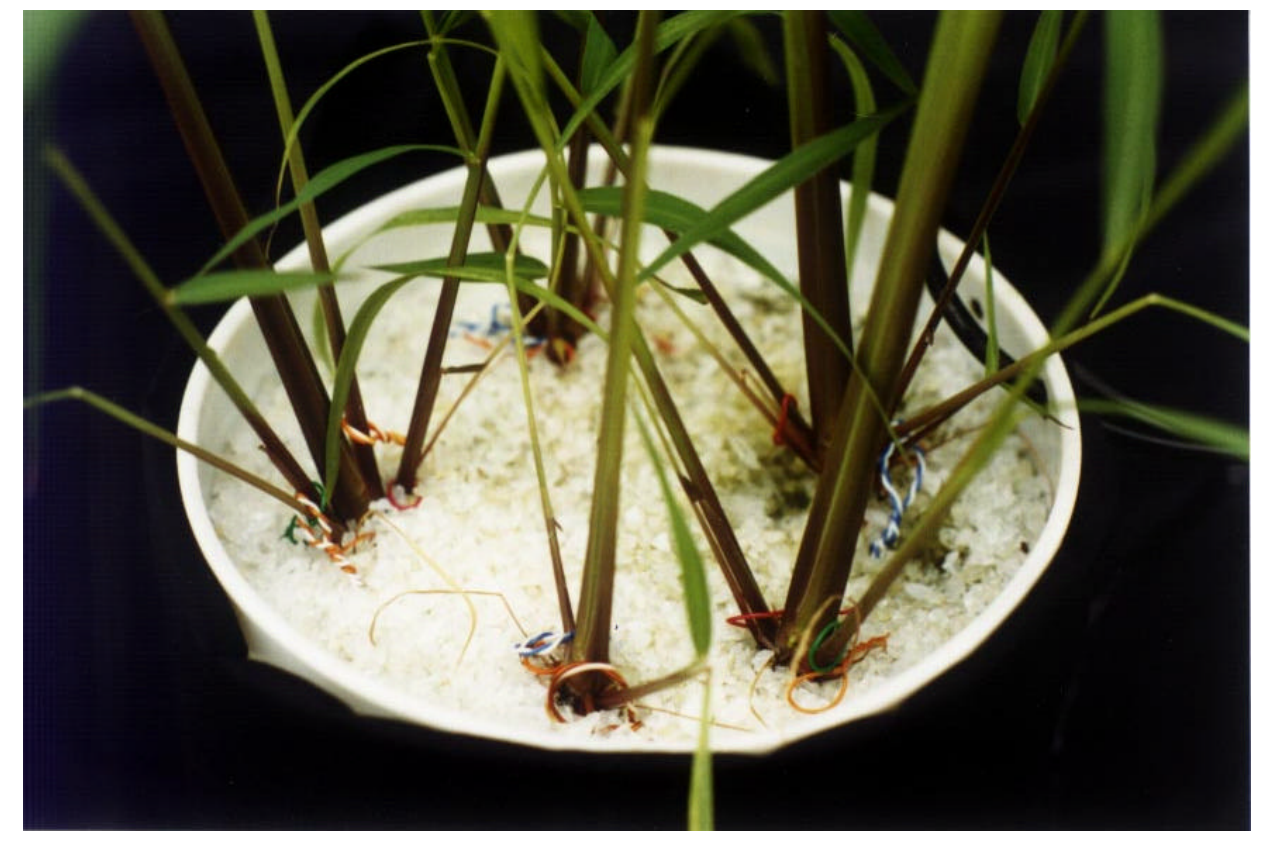

Figura 1 - llustração da marcação dos perfilhos do Panicum maximum cv. Mombaça com anéis coloridos.

\subsection{Estimativa do teor de clorofila}

Para a avaliação indireta do teor de clorofila nas folhas, foi empregado o clorofilômetro SPAD-502 (Soil and Plant Analysis Development) que fornece as leituras em unidades SPAD. O aparelho foi utilizado em folhas intactas, sendo a leitura correspondente à quantidade de clorofila presente na amostra (Figura 2). Os espectros de absorção são determinados com base na quantidade de luz transmitida pela folha amostrada em dois comprimentos de onda, sendo nas áreas do vermelho aproximadamente em $650 \mathrm{~nm}$ e infravermelho em 940 nm, onde os picos de absorção são máximo e mínimo, 
respectivamente. Nessa faixa as leituras não são influenciadas pela presença de outros pigmentos. A luz transmitida é convertida em sinais elétricos, que são digitalizados e microprocessados para cálculo em valor SPAD da medida de clorofila (Minolta Camera Corporation, 1989).

As leituras foram efetuadas diretamente (método não-destrutível) no terço-médio das lâminas de folhas recém-expandidas (no sentido do ápice para a base da planta), no dia anterior àrealização do primeiro e do segundo cortes. Considerou-se como valor representativo de cada repetição a média de quinze leituras executadas na lâmina foliar das plantas em cada vaso. Esse procedimento foi baseado em estudos anteriores realizados por Santos A. (1997).

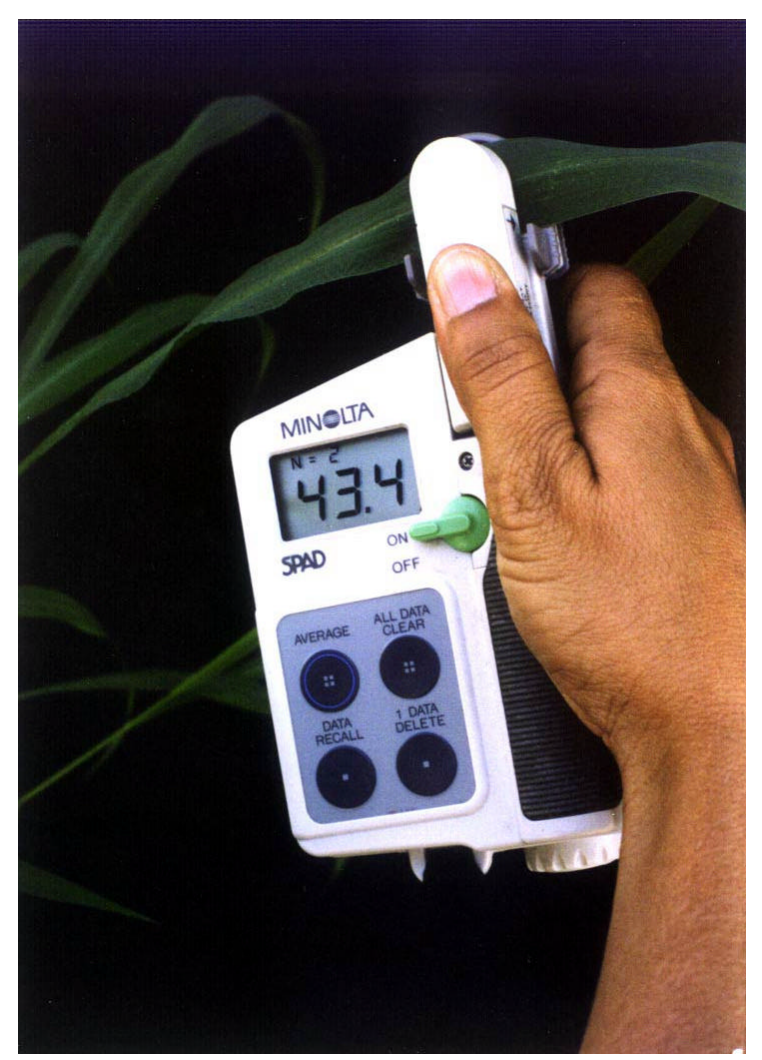

Figura 2 - llustração da avaliação indireta do teor de clorofila, medida em unidades SPAD através do clorofilômetro SPAD-502. 


\section{9 Área foliar}

Após cada corte, as folhas emergentes e as lâminas foliares (LN e LM) foram, separadamente, acondicionas em sacos plásticos e foram colocadas em caixas de isopor. Esse material foi levado ao laboratório para determinação da área foliar, através de medida no aparelho integrador de área foliar. Após a realização dessa medida o material vegetal foi acondicionado em sacos de papel identificados e foi levado para estufa secadora.

\subsection{Determinação no material vegetal}

\subsubsection{Produção de massa seca}

Para a obtenção dos resultados de produção de massa seca da parte aérea somaram-se os pesos dos seus componentes (folhas emergentes, lâminas de folhas recém-expandidas, lâminas de folhas maduras e colmos mais bainhas), enquanto o das raízes foi obtido diretamente pela pesagem do material.

\subsubsection{Análises químicas}

As determinações químicas dos nutrientes nos tecidos vegetais colhidos nos cortes da forrageira foram realizadas no Laboratório de Nutrição Mineral de Plantas da Escola Superior de Agricultura "Luiz de Queiroz", segundo a metodologia descrita por Sarruge \& Haag (1974).

A digestão utilizada para a determinação do potássio foi a nítricoperclórica, e o método analítico foi o de fotometria de chama. Para a determinação da concentração de magnésio em cada fração da parte aérea e 
das raízes a digestão utilizada foi a nítrico-perclórica, e o método analítico o de espectrofotometria de absorção atômica.

\subsubsection{Acúmulo de nutriente}

O acúmulo de nutriente na forrageira foi obtido multiplicando-se as concentrações do nutriente em cada componente (folhas emergentes, lâminas de folhas recém-expandidas, lâminas de folhas maduras e colmos+bainhas) pela produção de massa seca de cada componente. Para a parte aérea toda obteve-se esse acúmulo pela soma dos acúmulos do nutriente nos quatro componentes.

\subsubsection{Relação K:Mg}

Os resultados da relação $\mathrm{K}: \mathrm{Mg}$ foram obtidos pela divisão entre a concentração do potássio pela de magnésio em cada componente (folhas emergentes, lâminas de folhas recém-expandidas, lâminas de folhas maduras e colmos+bainhas) da planta.

\subsection{Análises estatísticas}

Os resultados foram analisados estatisticamente através da análise de variância $e$, nos casos de significância $(P<0,01)$, procedeu-se o estudo das regressões para os componentes de primeiro e de segundo grau; e teste de médias (Tukey 5\%) somente para o perfilhamento, distribuição porcentual do nutriente na parte aérea e relação $\mathrm{K}: \mathrm{Mg}$. Empregou-se o procedimento estatístico "Statistical Analysis System" (SAS Institute, 1996). 


\section{RESULTADOS E DISCUSSÃO}

Como os experimentos com Panicum maximum cv. Mombaça para as doses de potássio e magnésio foram conduzidos isoladamente os resultados também são apresentados e discutidos separadamente.

\subsection{Experimento com doses de potássio}

\subsubsection{Produção de massa seca da parte aérea e das raízes}

A produção de massa seca tanto da parte aérea como das raízes do capim-Mombaça variou significativamente $(P<0,01)$ com 0 incremento das doses de potássio na solução nutritiva.

No primeiro corte, a produção da parte aérea respondeu às doses de potássio segundo um modelo quadrático (Figura 3) e a produção máxima ocorreu com o nutriente na solução nutritiva em torno de $467 \mathrm{mg} \mathrm{L}^{-1}$. Resultado semelhante foi obtido por Mattos (1997) com Brachiaria decumbens, em que a máxima produção ocorreria na dose de $531 \mathrm{mg} \mathrm{L}^{-1}$. Essas doses podem ser consideradas altas quando comparada, à dose estabelecida no tratamento completo da solução de Sarruge (1975), que é de $234 \mathrm{mg} \mathrm{L}^{-1}$, evidenciando o potencial de resposta dos capins tropicais ao suprimento de nutrientes (neste caso, de potássio). 


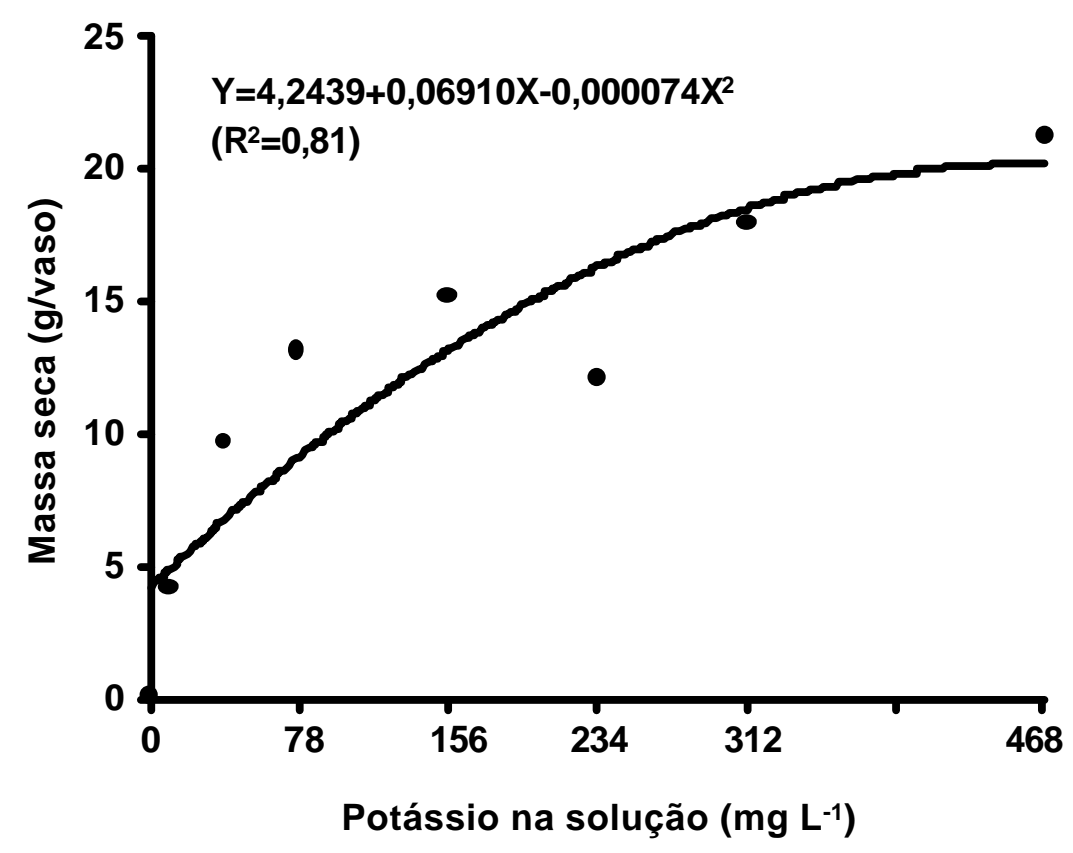

Figura 3 - Produção de massa seca da parte aérea no primeiro corte do Panicum maximum cv. Mombaça, em função das doses de potássio.

A dose para máxima produção das plantas foi mais elevada que a observada para o capim-Tanzânia-1 por Silva et al. (1995), que verificaram a máxima produção de massa seca na parte aérea com fornecimento de potássio de $348 \mathrm{mg} \mathrm{L}^{-1}$, por Mattos (1997) para Brachiaria brizantha com potássio em $365 \mathrm{mg} \mathrm{L}^{-1}$ e por Monteiro et al. (1999) para Brachiaria brizantha com potássio em $369 \mathrm{mg} \mathrm{L}^{-1}$ de solução nutritiva. No entanto, Benetti ${ }^{1}$ em experimento com oito doses de potássio $(0 ; 9,75 ; 39 ; 78 ; 156 ; 234 ; 312$ e $468 \mathrm{mg} \mathrm{L}^{-1}$ ) em solução nutritiva em capim-Vencedor e Silva et al. (1997) estudando doses de potássio e sódio em capim-Tanzânia-1 verificaram que a resposta em produção de massa seca da parte aérea, no primeiro corte

\footnotetext{
${ }^{1}$ BENETTI, I. Efeito de doses de potássio na produção e composição química de Panicum maximum Jacq. cv. Vencedor. São Paulo: ESALQ-USP. 1999. 31p. (Relatório Final de Estágio no Departamento de Solos e Nutrição de Plantas)
} 
desses capins, para as doses de potássio no substrato seguiu um modelo linear.

Para o segundo corte, os resultados da produção de massa seca da parte aérea também ajustaram-se a uma equação do segundo grau (Figura 4). A máxima produção de massa seca foi obtida com o potássio na solução nutritiva em $460 \mathrm{mg} \mathrm{L}^{-1}$. Esse resultado concorda com Benetti ${ }^{2}$, que verificou em capim-Vencedor a mais elevada produção de massa seca no segundo crescimento com dose de potássio abaixo da máxima estudada, de $435 \mathrm{mg} \mathrm{L}^{-1}$.

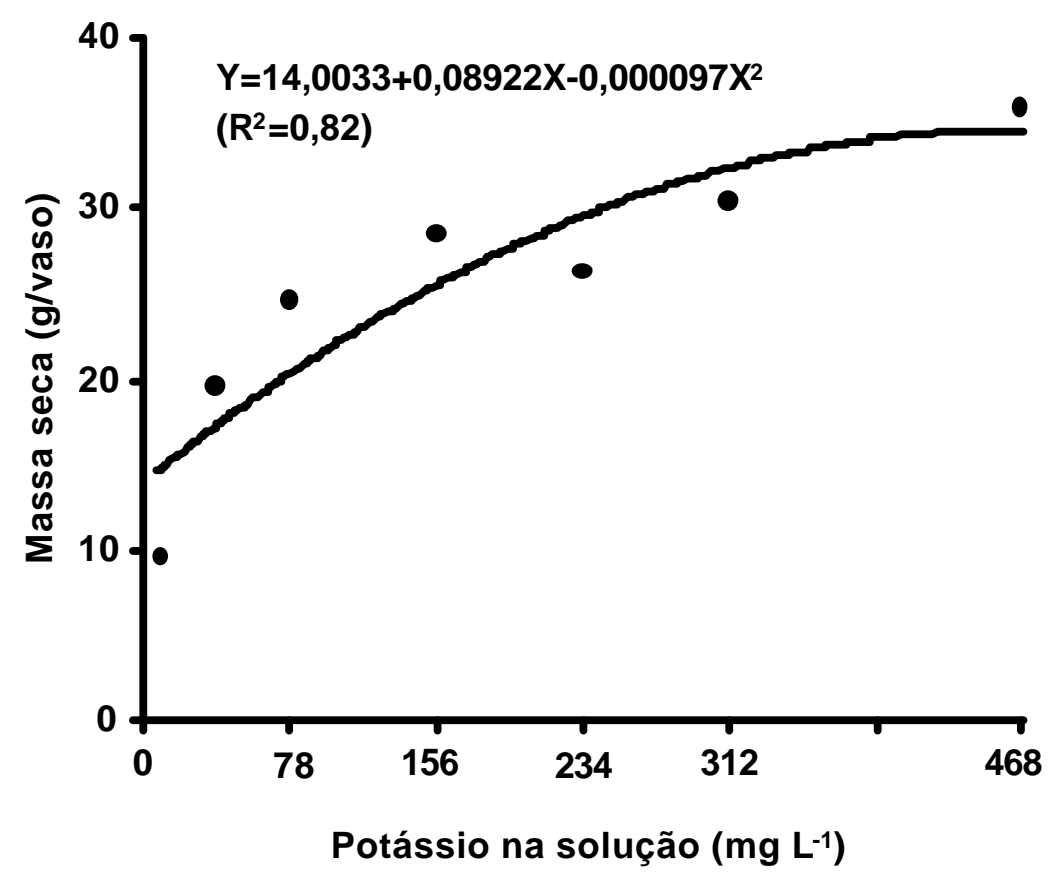

Figura 4 - Produção de massa seca da parte aérea no segundo corte do Panicum maximum cv. Mombaça, em função das doses de potássio.

A não aplicação de potássio limitou a produção de massa seca da parte aérea no capim-Mombaça, no primeiro e segundo cortes, sobretudo nesse

2 BENETTI, op. cit., p.39 
último, pois não houve sequer rebrota do capim nessa condição. Resultados semelhantes foram relatados com capim-Colonião por Werner \& Haag (1972), Hoffmann (1992) e Ferrari Neto et al. (1994).

O incremento significativo na produção de massa seca da parte aérea de plantas forrageiras como conseqüência do fornecimento de potássio foi relatado por Monteiro et al. (1980) com o capim-Colonião e por Silva et al. (1995) com o capim-Tanzânia-1. Herling et al. (1991) com capim-Setária e Silva (1992) com os capins Colonião e Andropogon, também constataram respostas significativas ao potássio, em relação à produção de massa seca da parte aérea. Vicente-Chandler et al. (1962), em Porto Rico, verificaram aumento na produção de massa seca quando a aplicação de potássio foi de até $400 \mathrm{~kg} \mathrm{ha}^{-1}$ ano $^{-1}$ para os capins Colonião, Napier e Pará. Gomide (1966), com capim-Gordura em três doses de N, P, K, Ca e S, verificou que a adubação potássica proporcionou incrementos na produção de massa seca quando os demais nutrientes tiveram seus suprimentos aumentados.

A produção de massa seca das raízes variou significativamente $(P<0,01)$ com as doses de potássio, ajustando-se a um modelo quadrático (Figura 5) e revelou seu ponto de máxima produção na dose de potássio de $357 \mathrm{mg} \mathrm{L}^{-1}$ de solução. Em baixas concentrações de potássio na solução as raízes eram finas e frágeis, rompendo facilmente durante a retirada dos vasos e nas sucessivas lavagens. Segundo Ferrari Neto (1991) esse fato ocorreu devido ao potássio que foi fornecido em solução ter sido absorvido e translocado para a parte aérea em intenso crescimento, porém em quantidades insuficientes para exercer a função de transportador de fotoassimilados até o sistema radicular. Ainda de acordo com o mesmo autor, a omissão de potássio proporcionou uma redução significativa na produção de massa seca na parte aérea e principalmente das raízes. Hartt (1969), trabalhando com cana-deaçúcar (Saccharum officinarum), afirmou que a redução na translocação ocorre antes do aparecimento de sintomas de deficiência de potássio, e que a 
pequena translocação de fotoassimilados da parte aérea para as raízes resulta em desproporcional crescimento das raízes em relação àparte aérea.

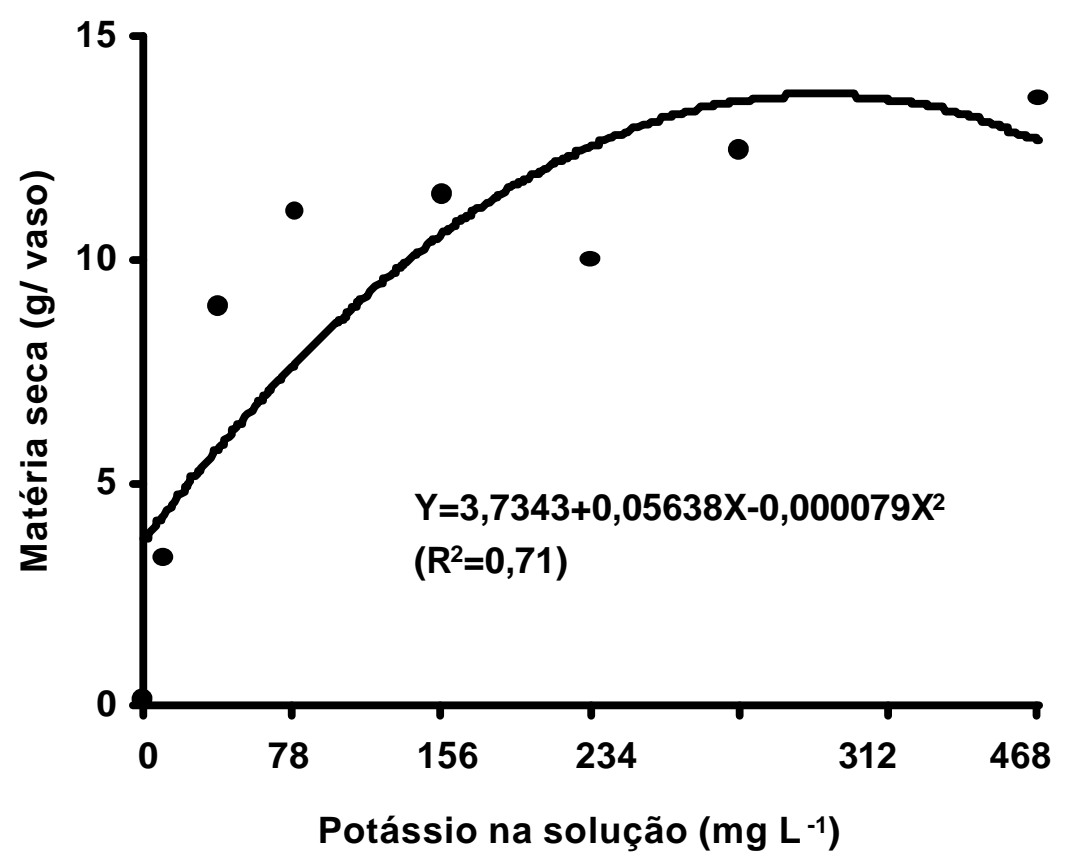

Figura 5 - Produção de massa seca das raízes do Panicum maximum cv. Mombaça, em função das doses de potássio.

\subsubsection{Número de perfilhos}

Os resultados apresentados nas Figuras 6 e 7 demonstram que 0 número de perfilhos nas cinco plantas do capim-Mombaça foi significativamente $(P<0,05)$ influenciado pela concentração de potássio na solução nutritiva, tanto no primeiro como no segundo corte das plantas.

$\mathrm{Na}$ primeira avaliação 0 número de perfilhos aumentou significativamente com o suprimento de potássio na solução de 0 para 
$9,75 \mathrm{mg} \mathrm{L}^{-1}$. O número de perfilhos diferiu entre as doses de potássio de $39 \mathrm{e}$ as de 312 e $468 \mathrm{mg} \mathrm{L}^{-1}$. Para as doses de potássio de 9,75; 39; 78; 156 e $234 \mathrm{mg} \mathrm{L}^{-1}$ não ocorreram diferenças significativas no número de perfilhos.

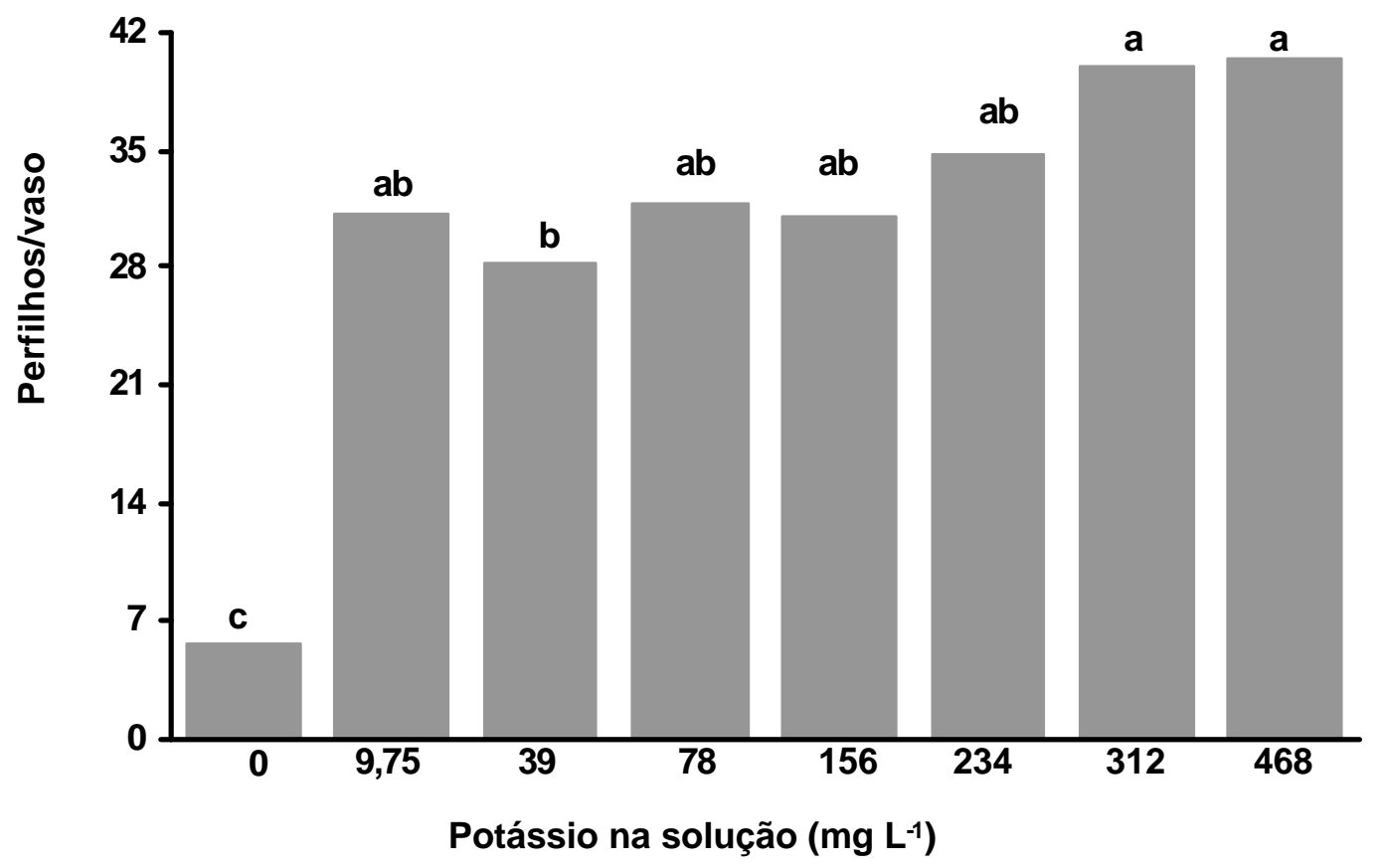

Figura 6 - Número de perfilhos nas cinco plantas do Panicum maximum cv. Mombaça, no primeiro corte, em função das doses de potássio na solução nutritiva. Letras diferentes indicam diferenças significativas ao nível de $5 \%$ de probabilidade (Tukey) .

Benetti \& Monteiro (1999) com capim-Vencedor e Mattos (1997) com Brachiaria decumbens observaram que o número de perfilhos, no primeiro crescimento, foi significativamente influenciado pelas doses de potássio em solução. Essas respostas ao potássio em relação ao perfilhamento seguem as mesmas tendências observadas para o capim-Mombaça. 


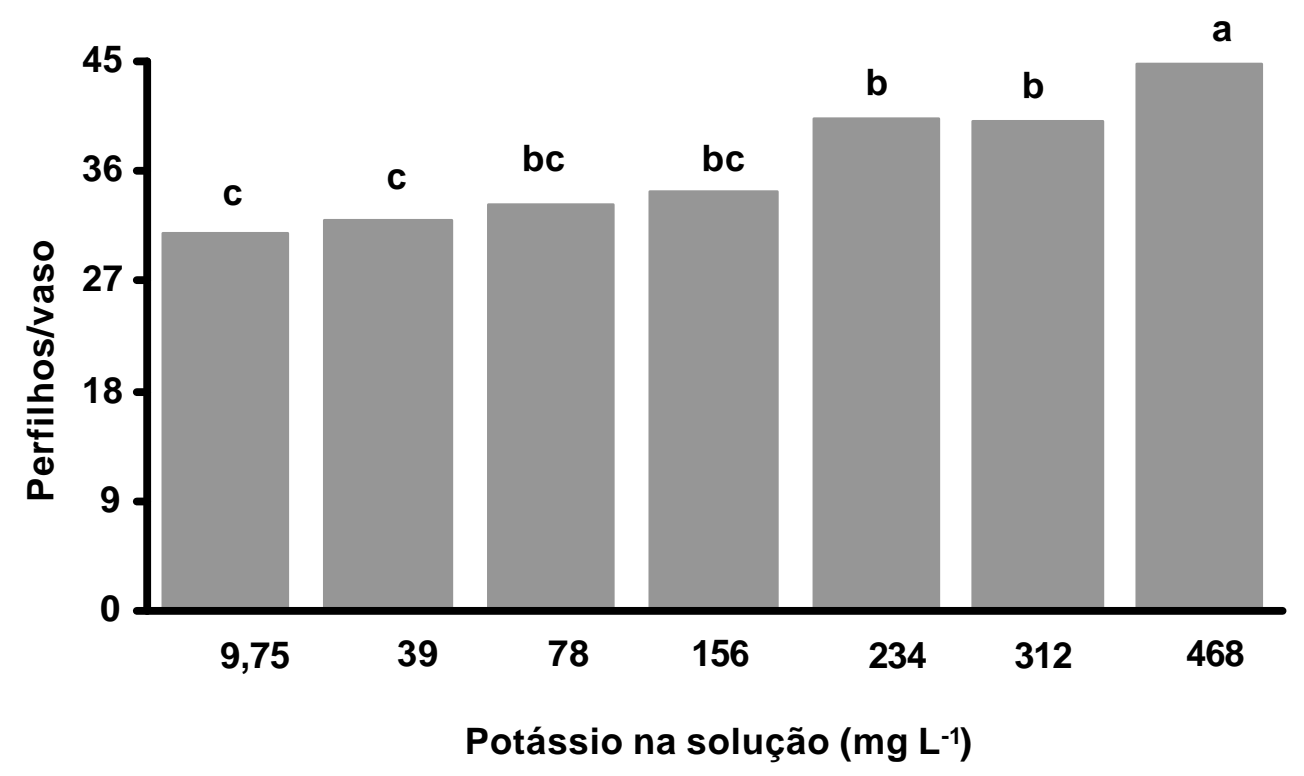

Figura 7 - Número de perfilhos nas cinco plantas do Panicum maximum cv. Mombaça, no segundo corte, em função das doses de potássio na solução nutritiva. Letras diferentes indicam diferenças significativas ao nível de $5 \%$ de probabilidade (Tukey).

No segundo crescimento, a omissão de potássio resultou em não rebrota e portanto, não houve perfilhamento das plantas. Não ocorreram diferenças significativas entre as doses de 9,75 a $156 \mathrm{mg} \mathrm{L}^{-1}$ no número de perfilhos. Também, diferenças não foram verificadas entre as doses de potássio de 78; 156; 234 e $312 \mathrm{mg} \mathrm{L}^{-1}$. Na dose máxima estudada, de $468 \mathrm{mg} \mathrm{L}^{-1}$ de solução, o número de perfilhos foi significativamente maior que o das demais doses de potássio avaliadas.

O número de perfilhos encontrado no primeiro crescimento foi inferior ao encontrado no segundo crescimento, provavelmente devido ao fato que na primeira fase a planta estava em formação da sua estrutura de parte aérea e sistema radicular. 
Silva et al. (1995) constataram diferenças no perfilhamento em capimTanzânia-1 entre as doses de potássio na solução, tendo a mais elevada concentração desse nutriente na solução mostrado 39\% mais perfilhos que a omissão do nutriente no substrato. Também, Ferrari Neto et al. (1994) relataram que o perfilhamento nos capins Colonião e Braquiária foi afetado pela carência de potássio.

Monteiro et al. (1999) descreveram que houve aumento no número de perfilhos de Brachiaria brizantha quando a dose de potássio foi incrementada de 39 para 234 ou $390 \mathrm{mg} \mathrm{L}^{-1}$. Mattos \& Monteiro (1998b) verificaram que o efeito das doses de potássio em solução nutritiva foi suficiente para promover significativas alterações no perfilhamento das plantas de Brachiaria brizantha nas doses de potássio de 312 e $468 \mathrm{mg} \mathrm{L}^{-1}$, tanto na época do primeiro como do segundo corte.

Carriel et al. (1989), trabalhando com capim-Colonião e Monteiro et al. (1995) com capim-Braquiária rão observaram variação significativa no número de perfilhos quando compararam a omissão de potássio em solução com o tratamento completo. Também, Hoffmann (1992) com capim-Colonião e Silva et al. (1997) com capim-Tanzânia-1 ressaltaram que o perfilhamento não respondeu significativamente ao suprimento de potássio.

Cultivando o capim-Tobiatã nas soluções nutritivas completa e com omissão de nutrientes, França \& Haag (1985) constataram que na omissão de potássio ocorreu mais baixo número de perfilhos e produção de massa seca que no tratamento completo.

\subsection{3 Área foliar}

Foram verificados incrementos significativos $(P<0,01)$ e lineares na área foliar do Panicum maximum cv. Mombaça com a adição do potássio na solução nutritiva, para as doses de potássio de 9,75 a $468 \mathrm{mg} \mathrm{L}^{-1}$. (Figuras 8 e 
9). Entretanto, não foi possível a avaliação da área foliar na ausência de suprimento desse nutriente. Esses resultados indicam que as medidas da área foliar poderiam ter valores mais elevados se as doses de potássio excedessem æ̀ avaliadas. Na dose mais elevada $\left(468 \mathrm{mg} \mathrm{L}^{-1}\right)$ foram encontrados valores para área foliar de 3.072 e $4.082 \mathrm{~cm}^{2} /$ vaso para o primeiro e segundo cortes, respectivamente.

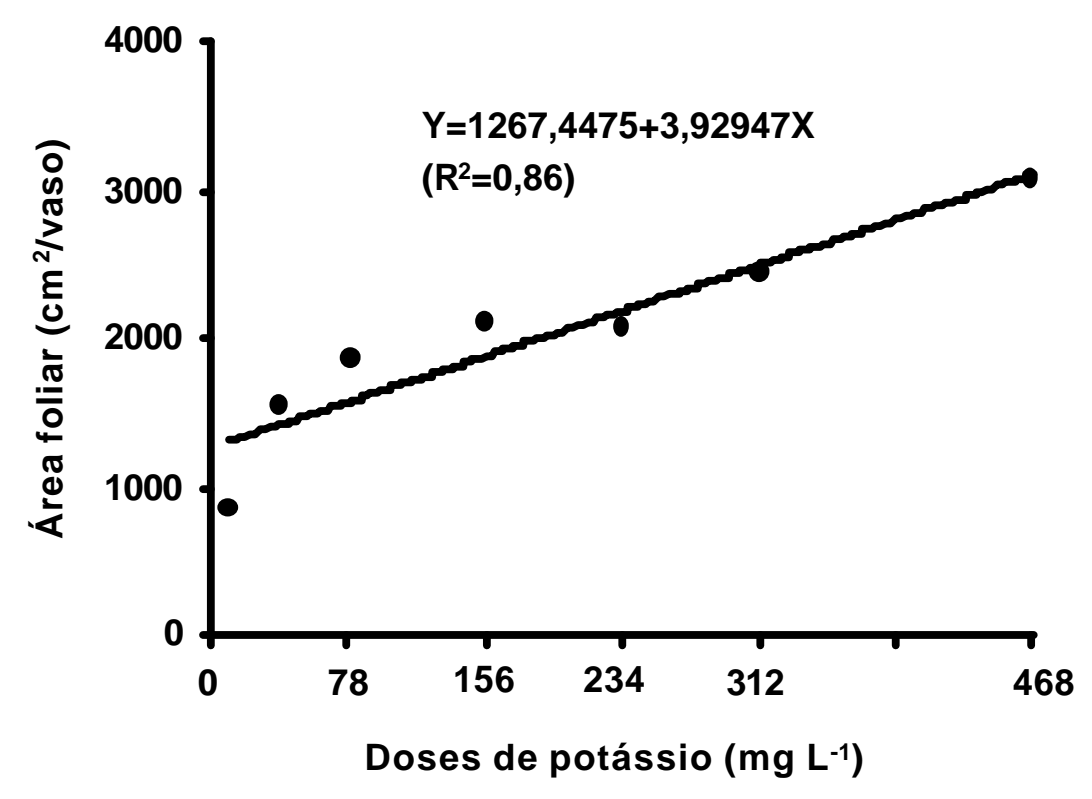

Figura 8 - Área foliar do Panicum maximum cv. Mombaça no primeiro corte, em função das doses de potássio. 


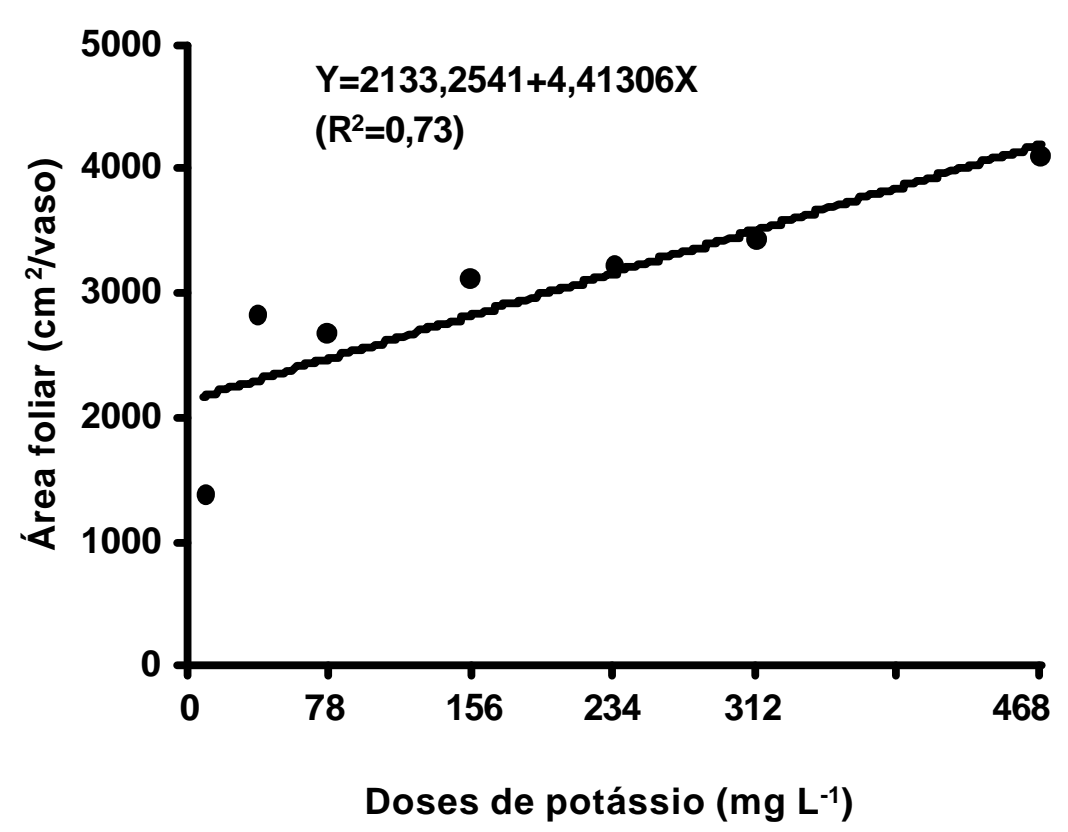

Figura 9 - Área foliar do Panicum maximum cv. Mombaça no segundo corte, em função das doses de potássio.

Meiri et al. (1992) avaliaram o crescimento de folhas de milho (Zea mays) verificaram a importância do potássio para o desenvolvimento foliar, sendo que sua principal função na taxa de expansão foliar parece estar relacionada àatividade da ATPase na membrana plasmática.

\subsubsection{Estimativa do teor de clorofila em valor SPAD}

A análise de variância não revelou variações significativas $(P>0,05)$ para as leituras de clorofila realizadas através do Chlorophyll Meter SPAD-502 nas lâminas de folhas recém-expandidas do capim-Mombaça, em ambos os crescimentos da gramínea forrageira em função das doses de potássio na solução. As médias para as leituras de clorofila nas doses $0 ; 9,75 ; 39 ; 156 ; 234$; 312 e $468 \mathrm{mg} \mathrm{L}^{-1}$ foram, respectivamente, de 42,$1 ; 44,5 ; 44,2 ; 40,9 ; 39,0$; 
41,2 e 42,5 para o primeiro corte e de 36,$9 ; 33,6 ; 33,0 ; 34,4 ; 31,5 ; 32,9$ e 31,3 para segundo corte.

\subsubsection{Concentração de potássio nos tecidos vegetais}

\subsubsection{Folhas emergentes}

As doses de potássio resultaram em efeitos significativos $(P<0,01)$ na concentração desse nutriente em folhas emergentes (FE) do Panicum maximum cv. Mombaça, em ambos os cortes.

No primeiro crescimento da planta forrageira, observoutse que a concentração de potássio nas folhas emergentes, em função das doses do nutriente, variaram conforme um modelo de segundo grau como mostrado na Figura 10. A máxima concentração de potássio nas folhas emergentes ocorreu na dose de potássio de $431 \mathrm{mg} \mathrm{L}^{-1}$, e a concentração de potássio na massa seca nessa parte da gramínea esteve entre 5,89 e 26,95 $\mathrm{g} \mathrm{kg}^{-1}$ para as doses de potássio 9,75 e $431 \mathrm{mg} \mathrm{L}^{-1}$, respectivamente. A dose para a máxima concentração de potássio foi mais elevada que a obtida por Mattos (1997) em Brachiaria decumbens, em que o ponto de máxima concentração de potássio em folhas emergentes ocorreu com o potássio em $346 \mathrm{mg} \mathrm{L}^{-1}$, enquanto a concentração do nutriente na massa seca variou de 11,50 a $35,45 \mathrm{~g} \mathrm{~kg}^{-1}$. 


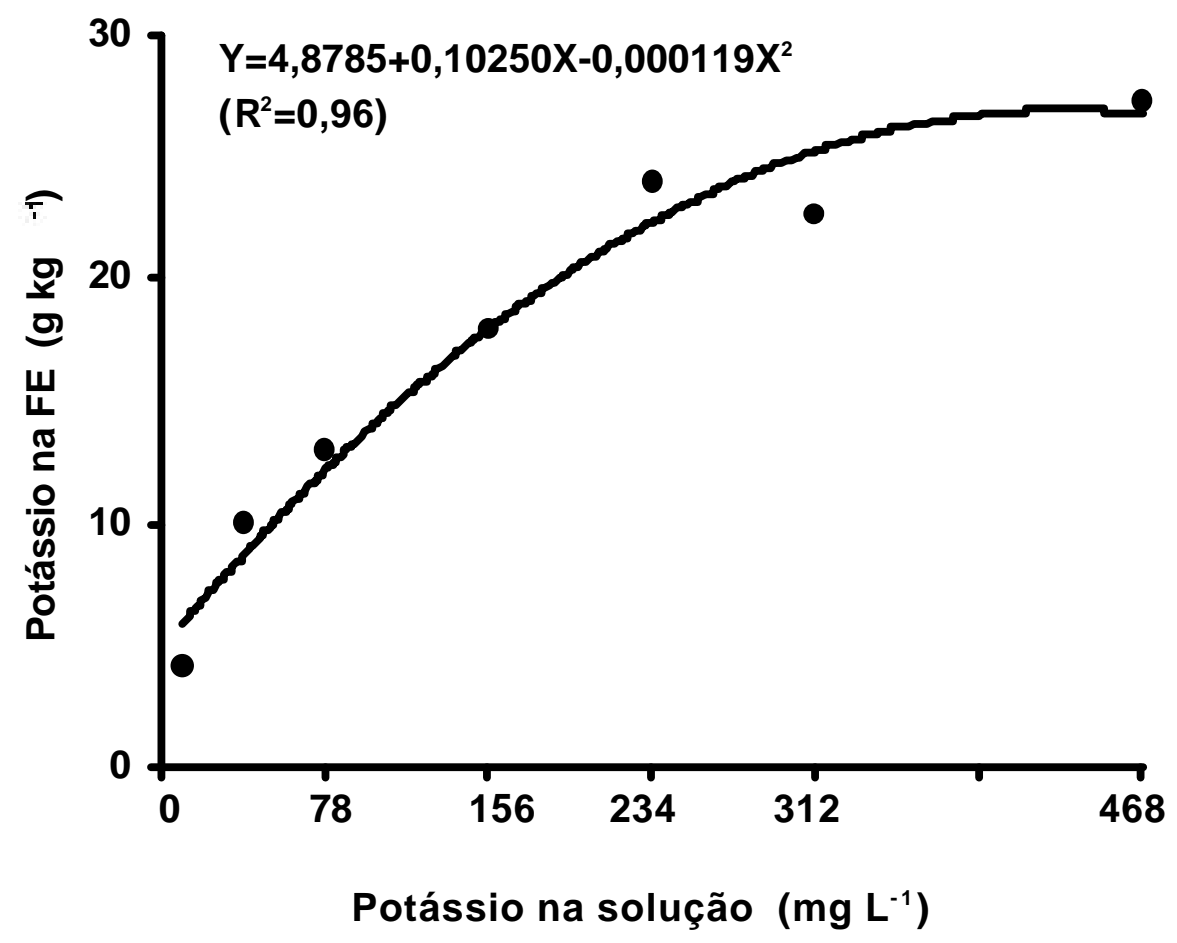

Figura 10 - Concentração de potássio nas folhas emergentes no primeiro corte do Panicum maximum cv. Mombaça, em função das doses de potássio na solução.

Para o segundo crescimento, a concentração de potássio em folhas emergentes, em função do potássio na solução, também ajustourse a uma equação do segundo grau (Figura 11). As concentrações de potássio variaram entre $5,37 \mathrm{~g} \mathrm{~kg}^{-1}$ quando a dose foi de $9,75 \mathrm{mg} \mathrm{L}^{-1}$ e $22,28 \mathrm{~g} \mathrm{~kg}^{-1} \mathrm{com}$ $409 \mathrm{mg} \mathrm{L}^{-1}$ de potássio em solução (dose esta em que foi verificada a máxima concentração de potássio nesse tecido do capim-Mombaça). Esse resultado é inferior ao encontrado por Benetti ${ }^{3}$ (1999) que obteve a máxima concentração de potássio em folhas emergentes do capim-Vencedor com a dose de potássio de $428 \mathrm{mg} \mathrm{L}^{-1}$, para o segundo crescimento.

${ }^{3}$ BENETTI, op. cit., p.39 


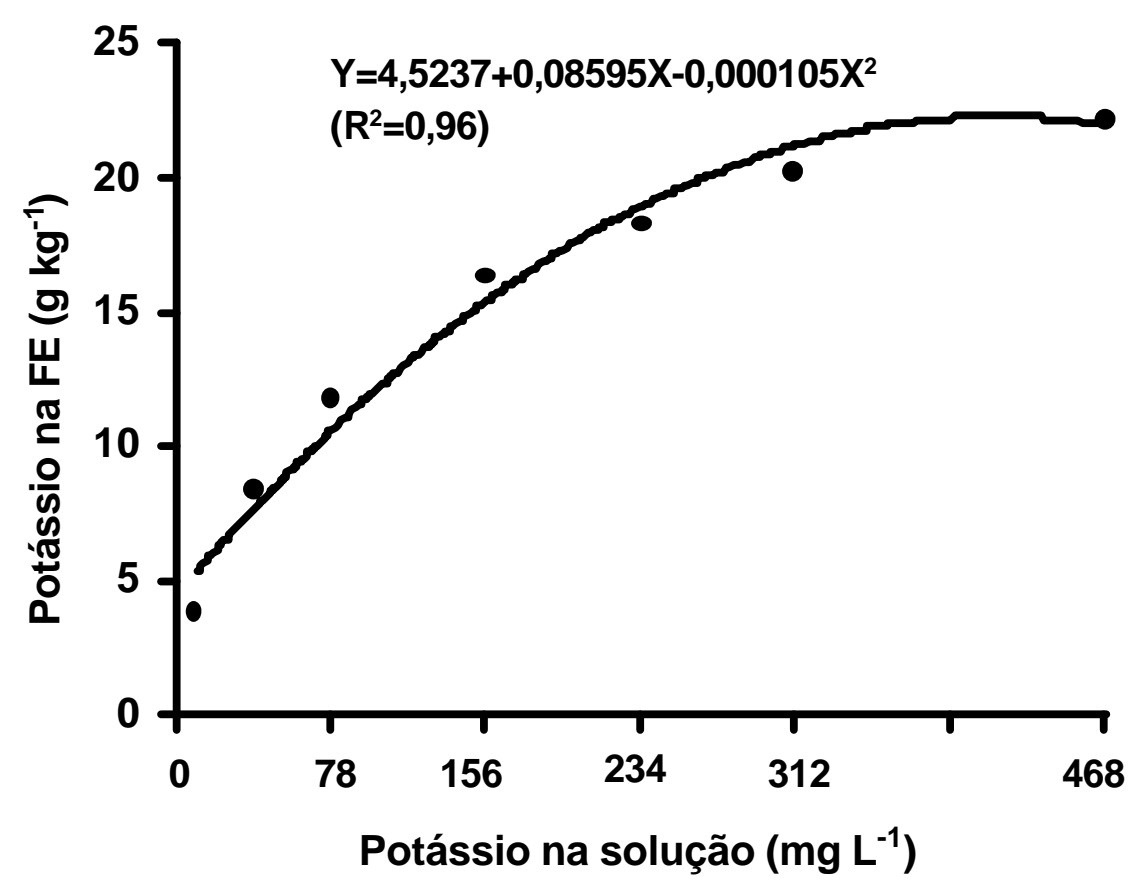

Figura 11 - Concentração de potássio nas folhas emergentes no segundo corte do Panicum maximum cv. Mombaça, em função das doses de potássio em solução.

Quando considerados os resultados em termos absolutos, a concentração de potássio nas folhas emergentes do capim-Mombaça revelaram que para o primeiro crescimento o ponto de máxima concentração ocorreu na dose de potássio de $431 \mathrm{mg} \mathrm{L}^{-1}$ que foi mais elevada que a dose $409 \mathrm{mg} \mathrm{L}^{-1}$ verificada no segundo crescimento. Isto provavelmente ocorreu devido a planta encontrar-se em crescimento, havendo assim, uma maior concentração do nutriente nessa parte da planta.

\subsubsection{Lâminas de folhas recém-expandidas}

A concentração de potássio nas lâminas de folhas recém-expandidas (LN) de Panicum maximum cv. Mombaça teve variação significativa $(P<0,01)$, tanto no primeiro como no segundo corte, em função do incremento de 
potássio na solução nutritiva. Os resultados ajustaram-se a modelos quadráticos em ambos os cortes.

No primeiro crescimento das plantas a concentração de potássio nas lâminas de folhas recém-expandidas da gramínea forrageira apresentou aumento pelas doses de potássio em solução até atingir o ponto de máxima concentração com a dose de potássio na solução de $409 \mathrm{mg} \mathrm{L}^{-1}$ (Figura 12). A variação na concentração do nutriente nessa parte amostrada da planta ficou

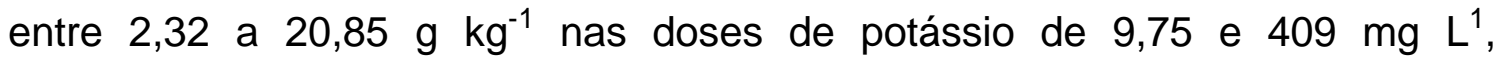
respectivamente. Entretanto, Mattos et al. (1996), avaliando doses de potássio (78; 156; 234 e $\left.312 \mathrm{mg} \mathrm{L}^{-1}\right)$ e de sódio $\left(11,5\right.$ e $\left.69 \mathrm{mg} \mathrm{L}^{-1}\right)$ em solução nutritiva para o capim-Tanzânia-1 verificaram que a relação entre doses de potássio e a concentração do nutriente em lâminas de folhas recém-expandidas apresentou comportamento linear crescente no primeiro corte.

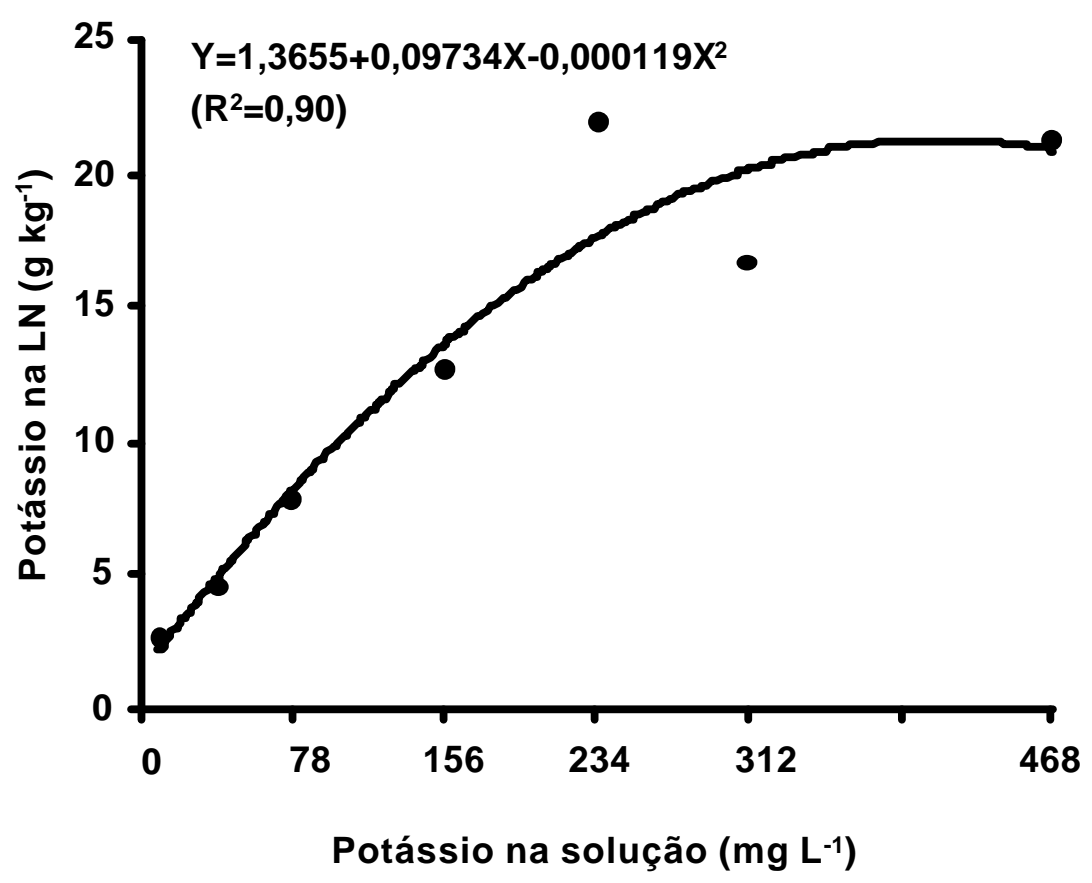

Figura 12 - Concentração de potássio nas folhas recém-expandidas no primeiro corte do Panicum maximum cv. Mombaça, em função das doses de potássio na solução. 
França \& Haag (1985) encontraram em capim-Tobiatã concentrações de potássio nas lâminas de folhas recém-expandidas da ordem de $31,1 \mathrm{~g} \mathrm{~kg}^{-1}$ no tratamento completo e de $7,5 \mathrm{~g} \mathrm{~kg}^{-1}$ quando foi omitido o potássio na solução nutritiva. Mattos (1997) observou aumento na concentração de potássio nas lâminas de folhas recém-expandidas de Brachiaria brizantha de 6,30 a $66,09 \mathrm{~g} \mathrm{~kg}^{-1}$ no primeiro corte, em função do aumento do potássio em solução de 9,75 a $468 \mathrm{mg} \mathrm{L}-1$. Constatou ainda que com o emprego de potássio de $456 \mathrm{mg} \mathrm{L}^{-1}$ na solução nutritiva resultou na máxima concentração de potássio nessas lâminas foliares da planta forrageira.

No material do segundo corte do Panicum maximum cv. Mombaça foi constatado que a concentração máxima do potássio nas lâminas de folhas recém-expandidas do capim estaria em $22,64 \mathrm{~g} \mathrm{~kg}^{-1}$ e que a dose $715 \mathrm{mg} \mathrm{L}^{-1}$ de potássio seria a que proporcionaria essa concentração (Figura 13). Essa dose de potássio na solução nutritiva é mais elevada que a máxima empregada no experimento. Também, Mattos et al. (1996) obtiveram uma equação de segundo grau para a concentração de potássio nas lâminas de folhas recémexpandidas do capim-Tanzânia-1, em função das doses de potássio, tendo seu ponto de máxima concentração do nutriente na dose de $365 \mathrm{mg} \mathrm{L}^{-1}$, a qual ficou abaixo da dose $\left(715 \mathrm{mg} \mathrm{L}^{-1}\right)$ máxima de potássio encontrada neste experimento. 


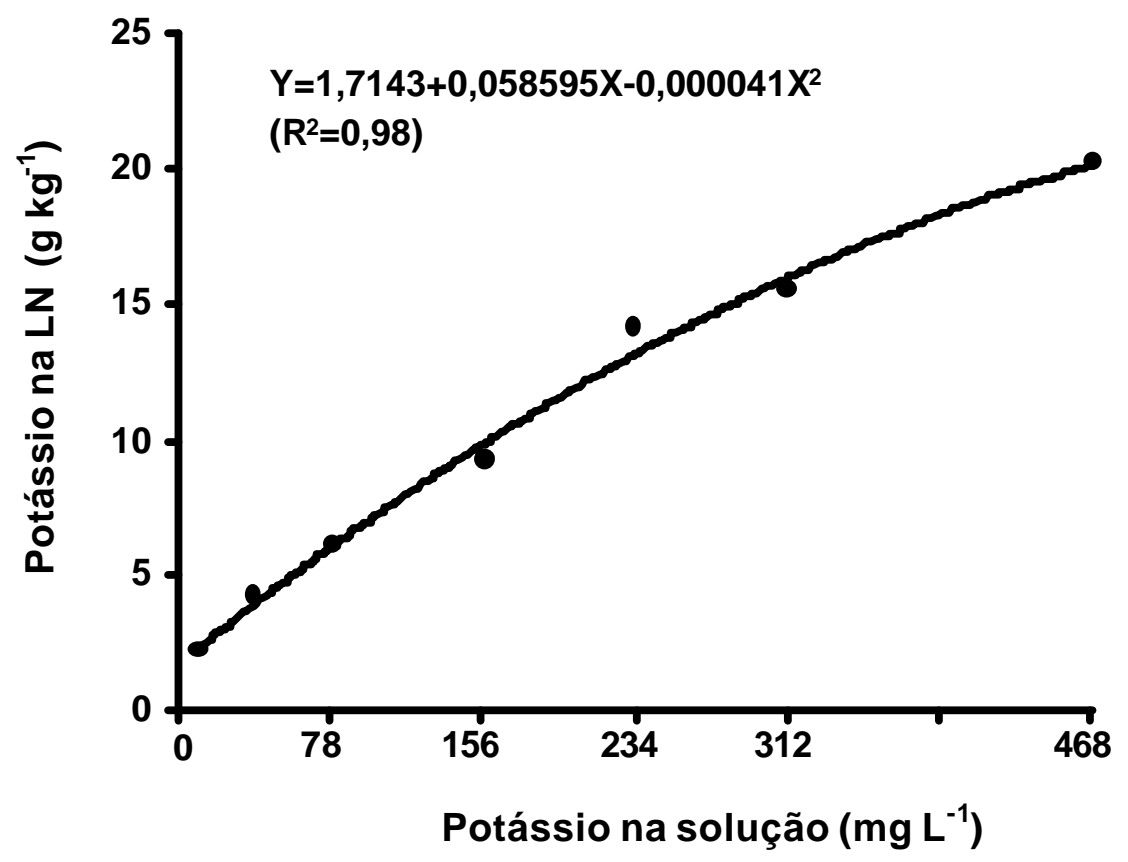

Figura 13 - Concentração de potássio nas folhas recém-expandidas no segundo corte do Panicum maximum cv. Mombaça, em função das doses de potássio na solução.

\subsubsection{Lâminas de folhas maduras}

Os resultados, tanto para o primeiro como no segundo crescimento do Panicum maximum cv. Mombaça, demonstram que o suprimento de potássio em solução nutritiva proporcionou variação significativa $(P<0,01)$ na concentração de potássio nas lâminas de folhas maduras (LM) do capim.

A equação de regressão da concentração de potássio no tecido do capim-Mombaça, no primeiro corte em função das doses de potássio, é de segundo grau (Figura 14). A partir dessa equação verificou-se que a máxima concentração de potássio $\left(26,92 \mathrm{~g} \mathrm{~kg}^{-1}\right.$ de massa seca) nas lâminas de folhas maduras do capim foi obtida na dose de potássio de $407 \mathrm{mg} \mathrm{L}^{-1}$ de solução. 


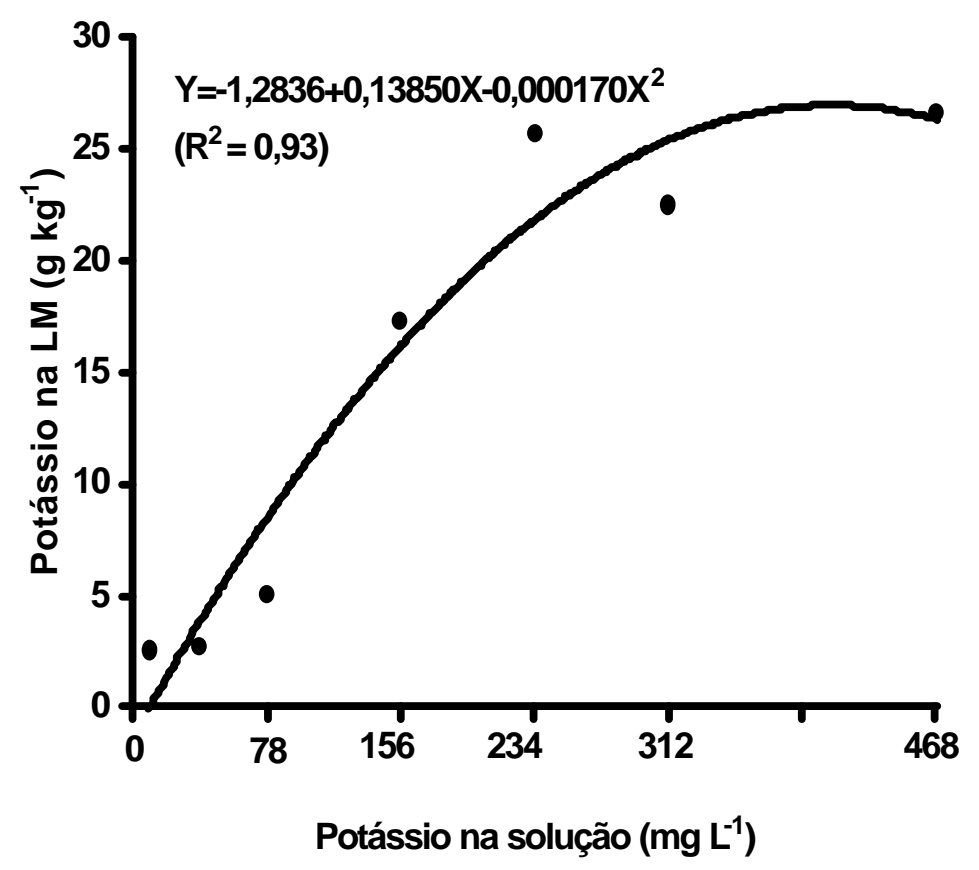

Figura 14 - Concentração de potássio nas folhas maduras no primeiro corte do Panicum maximum cv. Mombaça, em função das doses de potássio na solução.

A concentração de potássio nas lâminas de folhas maduras do capim-Mombaça, no segundo corte, apresentou ajuste ao modelo linear em função das doses de potássio (Figura 15). Esse resultado indica que a concentração de potássio nessa parte do capim-Mombaça continuaria se elevando além da maior dose utilizada de potássio na solução nutritiva. Assim, o mais alto valor dessa concentração foi de $27,82 \mathrm{~g} \mathrm{~kg}^{-1}$, obtido com a dose de potássio de $468 \mathrm{mg} \mathrm{L}^{-1}$, no presente experimento. Modelo linear para concentração de potássio nas lâminas de folhas maduras também foi observado por Silva et al. (1995), em trabalho com capim-Tanzânia-1 cultivado com doses de potássio em solução nutritiva, quando constataram valores de potássio de 0,33 e 2,67 $\mathrm{g} \mathrm{kg}^{-1}$ de massa seca obtidos nas doses de 9,75 e 312 $\mathrm{mg} \mathrm{L}^{-1}$, respectivamente. 


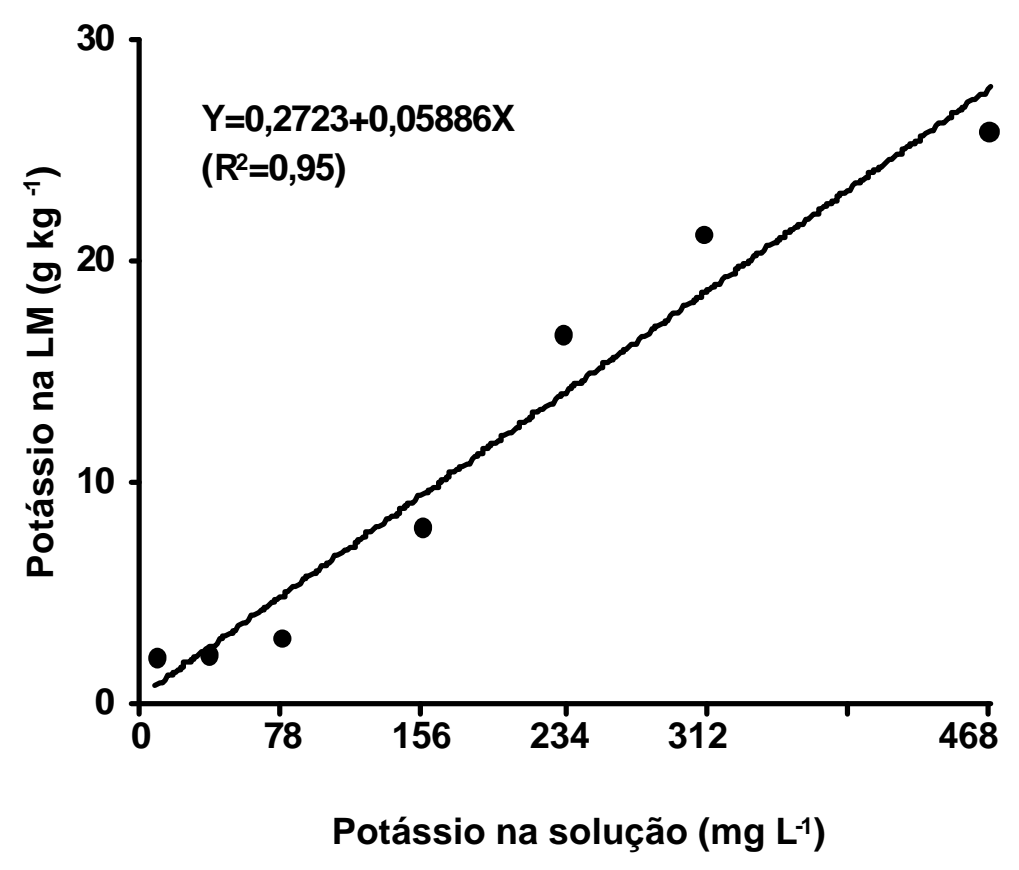

Figura 15 - Concentração de potássio nas folhas maduras no segundo corte do Panicum maximum cv. Mombaça, em função das doses de potássio na solução.

Benetti $^{4}$ observou, em capim-Vencedor, que o efeito das doses de potássio na concentração do nutriente nas lâminas de folhas maduras, no primeiro corte, variou segundo um modelo quadrático com ponto de máxima concentração de potássio no fornecimento de $645 \mathrm{mg} \mathrm{L}^{-1}$. Entretanto, no segundo corte os resultados referentes à concentração de potássio nessas lâminas foliares demonstraram efeito significativo das doses de potássio e ajuste a modelo linear. Também, Mattos et al. (1996) obtiveram relações lineares entre a concentração de potássio, para ambos os cortes, nas lâminas de folhas maduras do capim-Tanzânia-1 submetido e as doses de potássio na solução nutritiva

${ }^{4}$ BENETTI, op. cit., p.39 


\subsubsection{Colmos mais bainhas}

No primeiro crescimento observourse variação significativa $(P<0,01)$ na concentração de potássio nos colmos mais bainhas de Panicum maximum cv. Mombaça com a elevação da dose de potássio na solução nutritiva. Os resultados ajustaram-se a modelo quadrático de regressão.

A concentração de potássio nos colmos mais bainhas variou entre 2,83 $\mathrm{g} \mathrm{kg}^{-1}$ quando a dose de potássio era de 9,75 $\mathrm{mg} \mathrm{L}^{-1}$ até $39,23 \mathrm{~g} \mathrm{~kg}^{-1}$ para a dose de $389 \mathrm{mg}$ de $\mathrm{L}^{-1}$ de solução (nesta dose verificoutse a máxima concentração de potássio nessa parte da planta), como se pode observar na Figura 16.

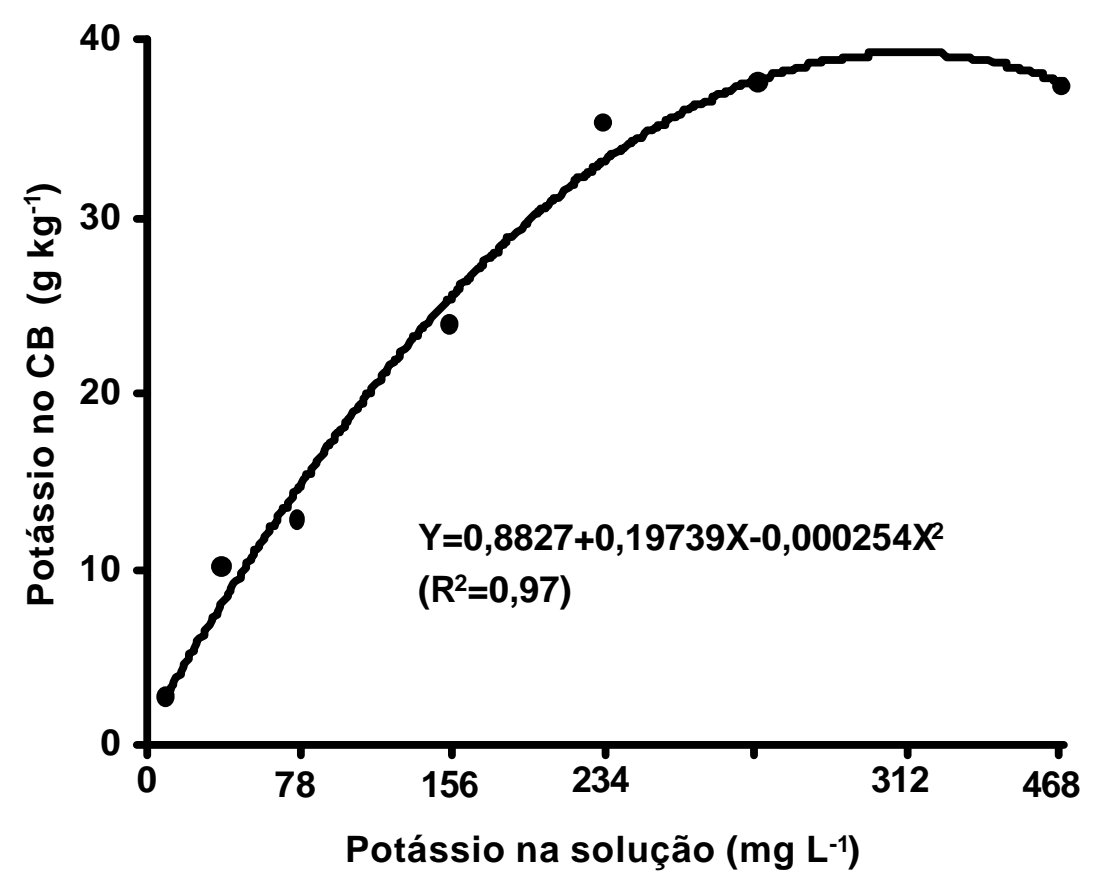

Figura 16 - Concentração de potássio nos colmos+bainhas no primeiro corte do Panicum maximum cv. Mombaça, em função das doses de potássio na solução. 
No material coletado ao final do segundo crescimento da planta forrageira (Figura 17) a concentração de potássio nos colmos mais bainhas também variou significativamente $(P<0,01)$ com as doses de potássio na solução, sendo os resultados ajustados a modelo de segundo grau. As concentrações de potássio nos colmos mais bainhas estiveram entre 0,76 e $31,84 \mathrm{~g} \mathrm{~kg}^{-1}$ na massa seca, sendo que o ponto de máxima concentração de potássio nessa parte da gramínea ocorreu com fornecimento de potássio em $384 \mathrm{mg} \mathrm{L}^{-1}$.

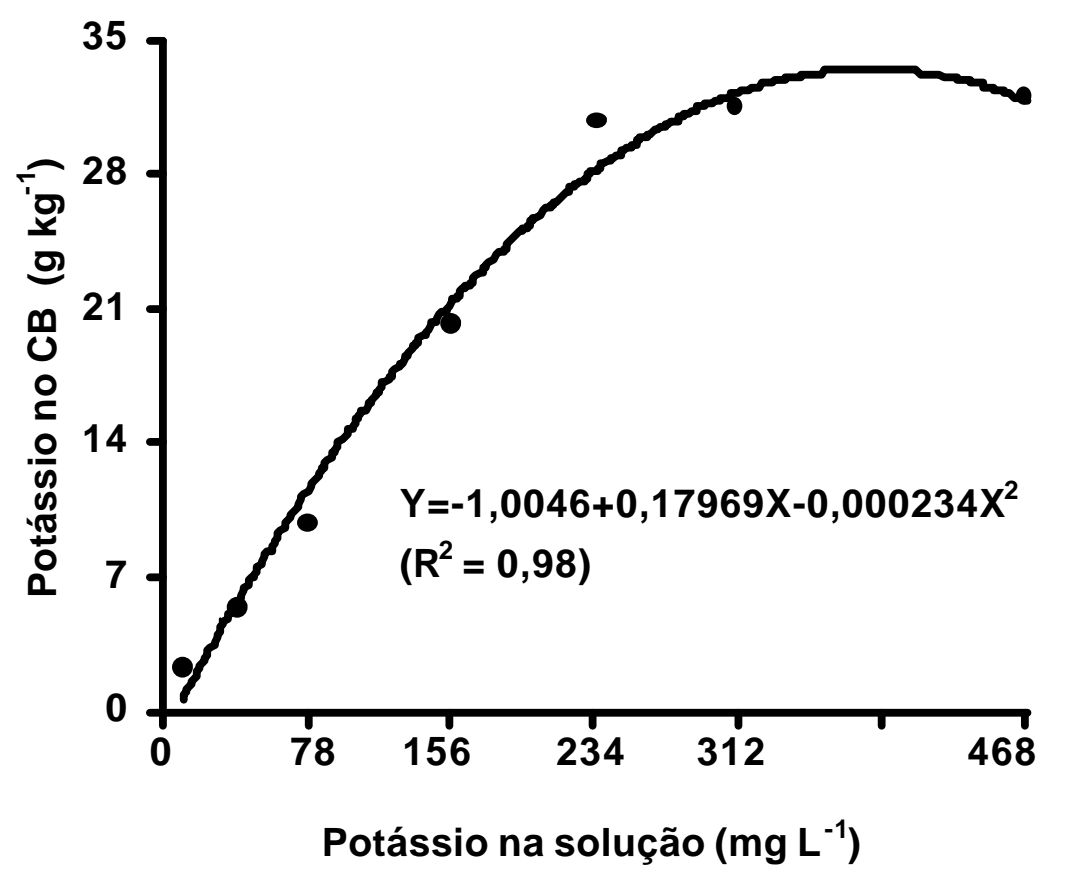

Figura 17 - Concentração de potássio nos colmos+bainhas no segundo corte do Panicum maximum cv. Mombaça, em função das doses de potássio na solução.

Mattos (1997) obteve, nos colmos mais bainhas de Brachiaria decumbens, em dois cortes da plantas, resultados que se ajustaram a uma equação de segundo grau na concentração de potássio em função das doses 
de potássio na solução nutritiva e apontou que as concentrações máximas de potássio nessa parte da gramínea ocorreram com fornecimento de potássio de 356 para o primeiro corte de e $377 \mathrm{mg} \mathrm{L}^{-1}$ para o segundo, esses resultados estão próximos aos obtidos nesse trabalho. Entretanto, Silva et al. (1995) descreveram relação linear para a concentração de potássio em colmos mais bainhas do capim-Tanzânia-1 com o suprimento de potássio na solução, variando de 0,34 a 2,84 $\mathrm{g} \mathrm{kg}^{-1}$ e de 0,02 a $3,02 \mathrm{~g} \mathrm{~kg}^{-1}$ de massa seca no primeiro e segundo cortes, respectivamente.

\subsubsection{Raízes}

Foram verificados incrementos significativos $(P<0,01)$ na concentração de potássio nas raízes do capim-Mombaça com a elevação das doses deste nutriente em solução (Figura 18).

A concentração de potássio apresentou ajuste a modelo linear em função das doses de potássio utilizadas na solução nutritiva. À medida em que se elevou a dose de potássio na solução ocorreu aumento na concentração de potássio no tecido, ou seja, a concentração de potássio nas raízes da gramínea forrageira poderia continuar se elevando além da maior dose de potássio em solução fornecida neste experimento.

Nas raízes do Panicum maximum cv. Mombaça as concentrações de potássio estiveram entre 1,8 a $13,0 \mathrm{~g} \mathrm{~kg}^{-1}$ de massa seca quando as doses variaram de 9,75 a $468 \mathrm{mg} \mathrm{L}^{-1}$, respectivamente. Benetti ${ }^{5}$ em capim-Vencedor e Mattos (1997) em capim-Braquiária também relataram que a concentração de potássio nas raízes variou significativamente com o fornecimento de potássio na solução nutritiva, tendo os resultados ajustados a modelo de primeiro grau.

\footnotetext{
${ }^{5}$ BENETTI, op. cit., p.39
} 


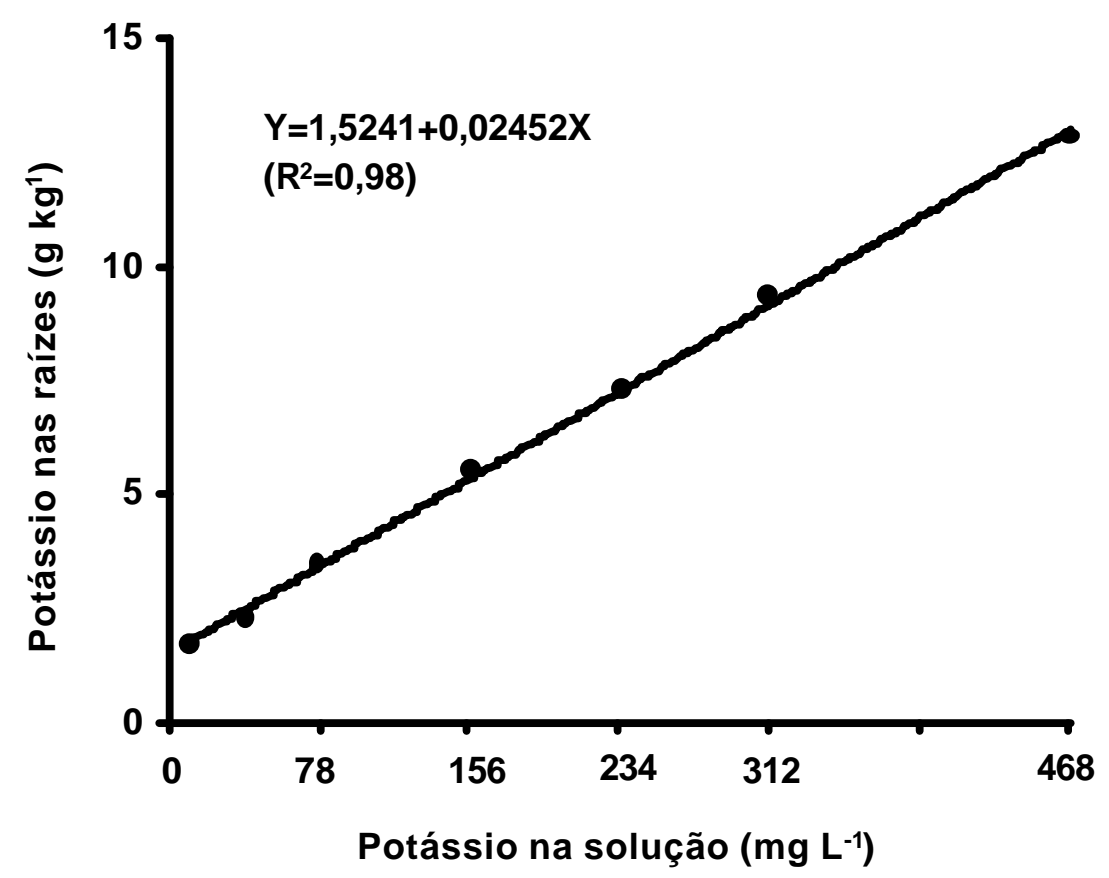

Figura 18 - Concentração de potássio nas raízes do Panicum maximum cv. Mombaça, em função das doses de potássio em solução.

\subsubsection{Acúmulo de potássio nos componentes da planta}

As equações de regressão referentes ao acúmulo de potássio nos componentes do capim-Mombaça, no primeiro e no segundo crescimentos, em função das doses de potássio na solução são mostrados na Tabela 3.

A análise de variância revelou variação significativa $(P<0,01)$ na quantidade de potássio acumulado nos componentes da parte aérea da planta, em função das doses de potássio na solução. 
Tabela 3. Equações de regressão referentes ao acúmulo de potássio nos componentes e na parte aérea do Panicum maximum cv. Mombaça, no primeiro e segundo crescimentos, em função das doses de potássio na solução.

\begin{tabular}{llc}
\hline \multicolumn{1}{c}{ Parte da planta } & \multicolumn{1}{c}{ Equação } & $R^{2}$ \\
\hline & \multicolumn{1}{c}{ Primeiro corte } & \\
Folhas emergentes & $\mathrm{Y}=4,9396+0,21794 \mathrm{X}$ & 0,96 \\
$\begin{array}{l}\text { Lâminas de folhas recém- } \\
\text { expandidas }\end{array}$ & $\mathrm{Y}=7,5324+0,35418 \mathrm{X}$ & 0,98 \\
Lâminas de folhas maduras & $\mathrm{Y}=-4,6505+0,29022 \mathrm{X}-0,00037 \mathrm{X}^{2}$ & 0,92 \\
Colmos+bainhas & $\mathrm{Y}=11,5701+0,57328 \mathrm{X}$ & 0,96 \\
Parte aérea & $\mathrm{Y}=29,8023+1,26405 \mathrm{X}$ & 0,98 \\
& & \\
& $\mathrm{Segundo}$ corte & 0,93 \\
Folhas emergentes & $\mathrm{Y}=14,9047+0,22481 \mathrm{X}$ & 0,99 \\
Lâminas de folhas recém- & $\mathrm{Y}=6,0908+0,5403 \mathrm{X}$ & \\
expandidas & & 0,98 \\
Lâminas de folhas maduras & $\mathrm{Y}=2,8951+0,17655 \mathrm{X}$ & 0,94 \\
Colmos+bainhas & $\mathrm{Y}=-22,1254+1,00589 \mathrm{X}-0,00184 \mathrm{X}^{2}$ & 0,99 \\
\hline Parte aérea & $\mathrm{Y}=-9,8780+2,94402 \mathrm{X}-0,00204 \mathrm{X}^{2}$ & \\
\hline
\end{tabular}

Resultados expressos em mg/vaso

Nas lâminas de folhas maduras do capim-Mombaça, no primeiro período de crescimento, os resultados de acúmulo do potássio ajustaram-se a uma equação do segundo grau em função das doses de potássio na solução nutritiva e o acúmulo máximo de potássio nessa parte da gramínea ocorreu com potássio em $392 \mathrm{mg} \mathrm{L}^{-1}$. Nas demais partes da planta não foi possível obter esse ponto de máximo, em vista dos ajustes terem sido lineares.

Para o segundo crescimento dessa planta forrageira os resultados de acúmulo de potássio nos colmos mais bainhas e na parte aérea ajustaram-se a 
modelos quadráticos. O ponto de máximo acúmulo de potássio nos colmos mais bainhas foi na dose de $273 \mathrm{mg} \mathrm{L}^{-1}$ e na parte aérea desse capim ocorreria com $721 \mathrm{mg} \mathrm{L}^{-1}$ de potássio na solução nutritiva, sendo maior que a dose máxima estudada.

$\mathrm{Na}$ Tabela 4 são apresentadas as distribuições porcentuais do acúmulo de potássio nos componentes (folhas emergentes, lâminas de folhas recém-expandidas, lâminas de folhas maduras e colmos mais bainhas) em relação à parte aérea dessa gramínea forrageira submetida a doses de potássio, em cada um dos crescimentos.

Nas folhas emergentes do capim-Mombaça, no primeiro crescimento, a proporção de potássio variou entre 14 a 26 \% em função das doses de potássio na solução, e diferiu estatisticamente das lâminas de folhas recémexpandidas nas doses 78 e $234 \mathrm{mg} \mathrm{L}^{-1}$. Para o segundo crescimento, houve decréscimo na proporção de potássio nessa parte da planta da dose de 9,75 a $312 \mathrm{mg} \mathrm{L}^{-1}$, e nesse crescimento a porcentagem de potássio não diferiu significativamente das lâminas recém-expandidas apenas nas doses de 9,75 e $78 \mathrm{mg} \mathrm{L}^{-1}$.

Nas lâminas de folhas recém-expandidas a proporção de potássio permaneceu na faixa de 24 a $30 \%$ e de 22 a $31 \%$, para o primeiro e segundo cortes, respectivamente. Não houve diferença significativa entre as lâminas de folhas recém-expandidas e as lâminas de folhas maduras do capim-Mombaça apenas nas doses de potássio de 9,75 e $156 \mathrm{mg} \mathrm{L}^{-1}$, no primeiro corte.

Pode-se observar que nas lâminas de folhas maduras o porcentual de potássio foi menor que o das folhas emergentes, nas lâminas de folhas recémexpandidas e nos colmos mais bainhas em ambos os crescimento, em todas as doses de potássio. Esses resultados podem ser justificados pela alta mobilidade do nutriente na planta e pelo fato do transporte à longa distância ocorrer pelo xilema e floema, sendo fácil a redistribuição pelo floema, pois o elemento se transloca das folhas e órgãos mais velhos para os mais novos. 
Tabela 4. Valores porcentuais da distribuição de potássio nos componentes do Panicum maximum cv. Mombaça em relação ao potássio acumulado na parte aérea nos dois períodos de crescimento, em função das doses de potássio.

\begin{tabular}{|c|c|c|c|c|}
\hline \multirow{2}{*}{$\begin{array}{c}\text { Doses de K } \\
\left(\mathrm{mg} \mathrm{L}^{-1}\right)\end{array}$} & \multicolumn{4}{|c|}{ Parte da planta } \\
\hline & $\mathrm{FE}$ & LN & LM & $\mathrm{CB}$ \\
\hline \multicolumn{5}{|c|}{ Primeiro corte } \\
\hline 0 ** & - & - & - & - \\
\hline 9,75 & $18,84 \mathrm{~b}$ & $27,15 a b$ & $18,61 \mathrm{~b}$ & $35,40 \mathrm{a}$ \\
\hline 39 & $25,67 b$ & $26,10 \mathrm{~b}$ & $5,02 \mathrm{c}$ & $43,21 \mathrm{a}$ \\
\hline 78 & $22,21 \mathrm{c}$ & $29,89 \mathrm{~b}$ & $6,22 d$ & $41,68 \mathrm{a}$ \\
\hline 156 & $15,40 \mathrm{~b}$ & $27,70 a b$ & $14,89 b$ & $42,01 \mathrm{a}$ \\
\hline 234 & $14,71 \mathrm{c}$ & $28,96 \mathrm{~b}$ & $13,66 \mathrm{c}$ & $42,67 \mathrm{a}$ \\
\hline 312 & $16,27 \mathrm{bc}$ & $24,58 \mathrm{~b}$ & $9,38 \mathrm{c}$ & $49,77 \mathrm{a}$ \\
\hline 468 & $18,99 \mathrm{bc}$ & $29,07 \mathrm{~b}$ & $8,65 c$ & $43,29 a$ \\
\hline \multicolumn{5}{|c|}{ Segundo corte } \\
\hline $0^{* *}$ & - & - & - & - \\
\hline 9,75 & $23,98 b$ & $30,45 a b$ & $8,33 \mathrm{c}$ & $37,24 \mathrm{a}$ \\
\hline 39 & $22,05 \mathrm{c}$ & $29,16 \mathrm{~b}$ & $3,93 \mathrm{~d}$ & $44,86 \mathrm{a}$ \\
\hline 78 & $20,05 b$ & $27,18 b$ & $3,23 \mathrm{c}$ & $49,54 \mathrm{a}$ \\
\hline 156 & $14,78 \mathrm{c}$ & $22,08 \mathrm{~b}$ & $5,45 d$ & 57,69 a \\
\hline 234 & $12,31 \mathrm{c}$ & $22,53 \mathrm{~b}$ & $7,08 d$ & $58,08 \mathrm{a}$ \\
\hline 312 & $11,68 \mathrm{c}$ & $24,98 \mathrm{~b}$ & $7,87 \mathrm{c}$ & $55,47 \mathrm{a}$ \\
\hline 468 & $12,72 \mathrm{c}$ & $28,31 \mathrm{~b}$ & $8,50 \mathrm{c}$ & $50,47 \mathrm{a}$ \\
\hline
\end{tabular}

$\mathrm{FE}=$ Folhas emergentes; $\mathrm{LN}=$ Lâminas de folhas recém-expandidas; LM= Lâminas de folhas maduras; $\mathrm{CB}=$ Colmos+bainhas.

** Por insuficiência de material, não houve determinação do potássio no tecido vegetal. Letras diferentes nas linhas indicam diferenças significativas ao nível de 5\% de probabilidade (Tukey). 
Verificou-se, também que 35 a $59 \%$ do total de potássio presente na parte aérea do capim-Mombaça estava na fração colmos mais bainhas em todas as doses estudadas, não diferindo estatisticamente das lâminas de folhas recém-expandidas nas doses 9,75 e $156 \mathrm{mg} \mathrm{L}^{-1}$ para o primeiro crescimento e apenas na dose $9,75 \mathrm{mg} \mathrm{L}^{-1}$ para o segundo crescimento. Esses resultados indicam que a mais elevada concentração de potássio está nessa fração da planta. No segundo crescimento, os colmos mais bainhas mostraram conter proporção crescente do potássio na parte aérea, à medida em que se incrementou o fornecimento de potássio até a dose $234 \mathrm{mg} \mathrm{L}^{-1}$ de solução. Resultados semelhantes foram relatados por Mattos (1997), avaliando a distribuição porcentual da quantidade acumulada de potássio em Brachiaria brizantha cv. Marandu submetidas as doses de potássio, verificou o maior e menor valor porcentual, em ambos os cortes, encontravam-se respectivamente nos colmos mais bainhas e nas lâminas de folhas maduras .

\subsubsection{Nível crítico de potássio}

Para avaliação do nível crítico adotoutse o critério estabelecido por Ulrich \& Hills (1973), que definiu o nível crítico como a concentração do nutriente que corresponde a $90 \%$ da produção máxima da cultura.

No primeiro e segundo crescimentos verificaram-se relações significativas $(P<0,01)$ entre as concentrações de potássio em folhas emergentes e de lâminas de folhas recém-expandidas com a produção de massa seca da parte aérea. As lâminas de folhas recém-expandidas tiveram mais altos coeficientes para essa correlação.

Os coeficientes de correlação entre as concentrações de potássio nos componentes da parte aérea e a produção de massa seca da parte aérea foram determinados nos dois crescimentos do capim-Mombaça. No primeiro crescimento esse coeficiente teve valor de 0,70 para as folhas emergentes, foi 
de 0,81 para as lâminas de folhas recém-expandidas, alcançou 0,63 para as lâminas de folhas maduras e atingiu 0,68 para os colmos+bainhas. Para o segundo crescimento foram verificados os valores de coeficiente 0,$85 ; 0,92$; 0,76 e 0,83 ; respectivamente para as quatro partes amostradas nas plantas. Examinando essas relações, pode-se determinar que entre os componentes da planta forrageira a amostragem das lâminas de folhas recém-expandidas é indicada para a avaliação do estado nutricional do potássio no capim-Mombaça. A utilização desta parte da planta para avaliação do estado nutricional em potássio é importante não apenas pelos mais altos coeficientes de correlação e maior estabilidade dos resultados em relação àamostragem em que se recolhe toda a parte aérea, como também pela facilidade de amostragem do material.

Os valores de nível crítico de potássio observados na amostragem de lâminas de folhas recém-expandidas para o material do primeiro e segundo cortes foram de 15,4 e 17,3 $\mathrm{g} \mathrm{kg}^{-1}$ de massa seca, respectivamente (Figuras 19 e 20). Esses resultados estão próximos aos encontrados por Carriel et al. (1989) que obtiveram o nível crítico de potássio de $11,0 \mathrm{~g} \mathrm{~kg}^{-1}$ no primeiro corte e $13 \mathrm{~g} \mathrm{~kg}^{-1}$ no segundo corte, para o capim-Colonião. Faquin et al. (1995), também em capim-Colonião, verificaram que o nível crítico de potássio na parte aérea no primeiro e segundo crescimentos, correspondente a $90 \%$ da produção máxima, foi de $14,6 \mathrm{~g} \mathrm{~kg}^{-1}$ e de $9,5 \mathrm{~g} \mathrm{~kg}^{-1}$, respectivamente. 


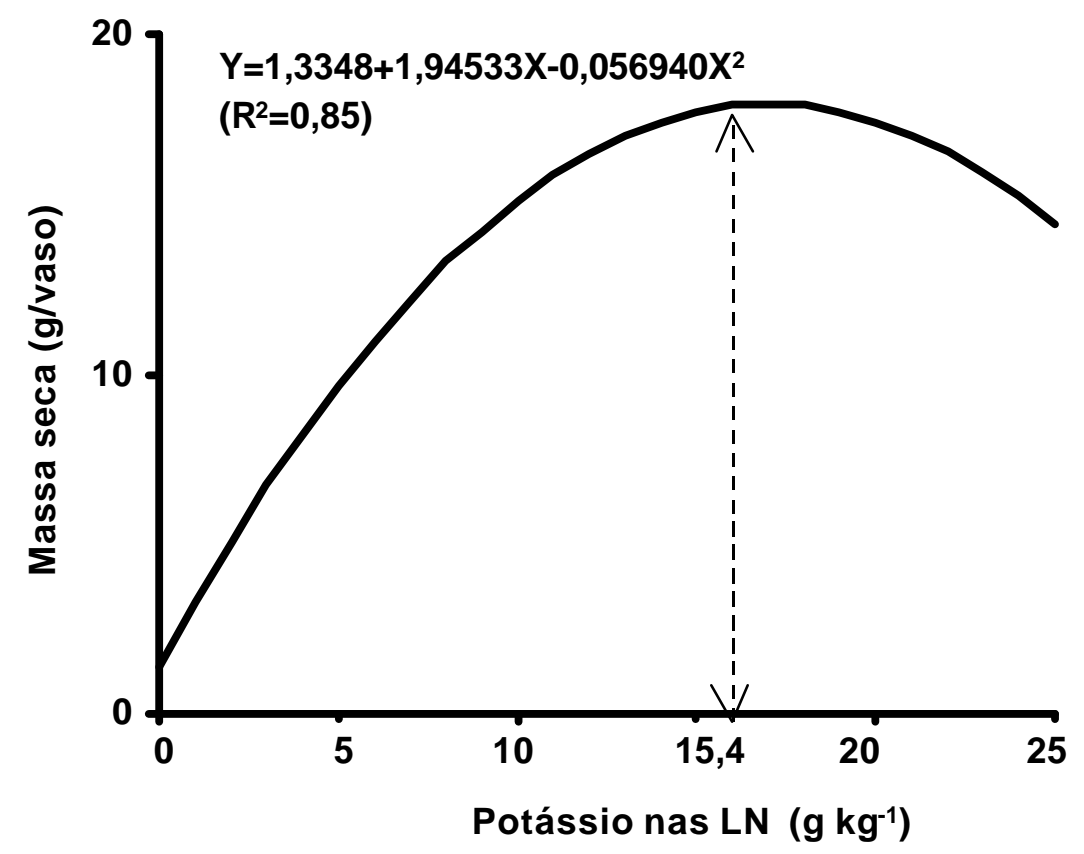

Figura 19 - Relação entre a concentração de potássio nas lâminas de folhas recém-expandidas no primeiro corte e a produção de massa seca da parte aérea do Panicum maximum cv. Mombaça.

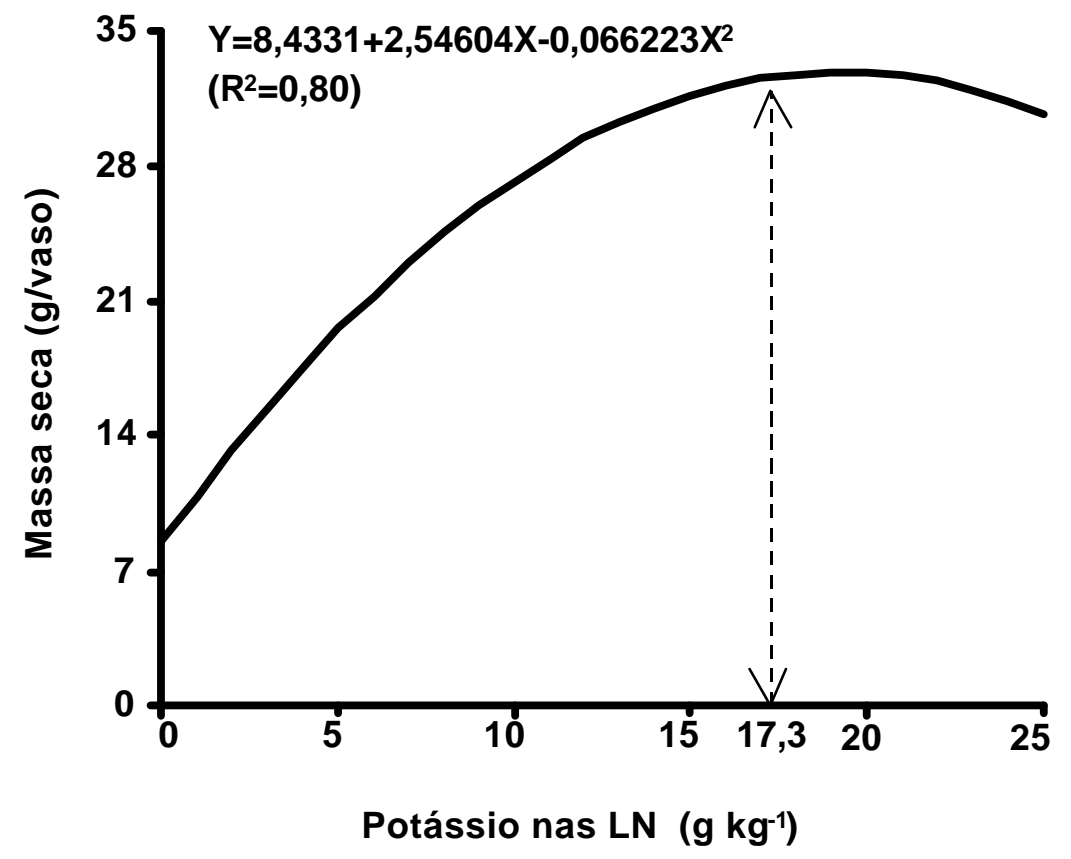

Figura 20 - Relação entre a concentração de potássio nas folhas lâminas de recém-expandidas no segundo corte e a produção de massa seca da parte aérea do Panicum maximum cv. Mombaça. 
Gallo et al. (1974) estudaram a composição química de gramíneas forrageiras amostradas no Estado de São Paulo, e observaram que a concentração de potássio em todas as amostras esteve acima de $8,0 \mathrm{~g} \mathrm{~kg}^{-1}$. Constataram que a concentração média no capim-Colonião foi de $21,0 \mathrm{~g} \mathrm{~kg}^{-1} \mathrm{e}$ que cerca de $74 \%$ do total de amostras tiveram concentrações de potássio na faixa de 12,0 a $28,0 \mathrm{~g} \mathrm{~kg}^{-1}$.

\subsubsection{Relação K: Mg no capim-Mombaça}

A relação entre as concentrações de potássio e magnésio (K:Mg) foi avaliada nos componentes do capim-Mombaça em função das doses de potássio na solução, em ambos os cortes, estando os resultados apresentados na Tabela 5.

No primeiro crescimento das plantas ocorreu um aumento nos valores da relação entre potássio e magnésio, em função das doses de potássio em solução em todos os componentes da parte aérea da planta. Os maiores valores dessa relação foram encontrados nas folhas emergentes e nos colmos mais bainhas.

Nas lâminas de folhas recém-expandidas e lâminas de folhas maduras foram encontrados os valores absolutos mais baixos da relação $\mathrm{K}: \mathrm{Mg}$ em função das doses de potássio, onde a menor variação entre o máximo e o mínimo valor observado foi verificado nas folhas maduras (12,4 vezes).

As folhas emergentes diferiram significativamente das lâminas de folhas recém-expandidas, das lâminas de folhas maduras e dos colmos+bainhas, no primeiro corte, nas doses 9,75; 78; 312 e $468 \mathrm{mg} \mathrm{L}^{-1}$. Entretanto, no segundo corte essa parte da planta forrageira diferiu dos demais componentes da parte aérea em todas as doses avaliadas neste experimento. 
Tabela 5. Relação entre as concentrações de potássio e de magnésio (K:Mg) nos componentes da parte aérea do Panicum maximum cv. Mombaça em função das doses de potássio em solução, nos dois cortes.

\begin{tabular}{|c|c|c|c|c|}
\hline \multirow{2}{*}{$\begin{array}{c}\text { Doses de K } \\
\left(\mathrm{mg} \mathrm{L}^{-1}\right)\end{array}$} & \multicolumn{4}{|c|}{ Parte da planta } \\
\hline & FE & LN & LM & $\mathrm{CB}$ \\
\hline \multicolumn{5}{|c|}{ Primeiro corte } \\
\hline 0 ** & - & - & - & - \\
\hline 9,75 & $1,21 \mathrm{a}$ & $0,55 \mathrm{~b}$ & $0,37 \mathrm{~b}$ & $0,41 \mathrm{~b}$ \\
\hline 39 & $3,68 \mathrm{a}$ & $1,10 \mathrm{a}$ & $0,31 \mathrm{a}$ & $2,79 a$ \\
\hline 78 & $6,00 \mathrm{a}$ & $2,34 \mathrm{~b}$ & $1,08 b$ & $2,06 \mathrm{~b}$ \\
\hline 156 & $7,82 \mathrm{a}$ & $4,09 a$ & $3,83 a$ & $4,69 \mathrm{a}$ \\
\hline 234 & $8,24 a$ & $5,45 a b$ & $3,19 b$ & $7,00 a b$ \\
\hline 312 & $15,75 a$ & $6,46 \mathrm{bc}$ & $3,83 \mathrm{c}$ & $10,57 \mathrm{~b}$ \\
\hline 468 & $19,94 \mathrm{a}$ & $10,30 \mathrm{~b}$ & $4,60 \mathrm{c}$ & $12,44 \mathrm{~b}$ \\
\hline \multicolumn{5}{|c|}{ Segundo corte } \\
\hline 0 ** & - & - & - & - \\
\hline 9,75 & $1,09 \mathrm{a}$ & $0,45 \mathrm{~b}$ & $0,24 c$ & $0,33 \mathrm{bc}$ \\
\hline 39 & $4,01 \mathrm{a}$ & $1,09 \mathrm{~b}$ & $0,19 c$ & $0,92 \mathrm{~b}$ \\
\hline 78 & $6,63 \mathrm{a}$ & $1,77 b$ & $0,32 \mathrm{c}$ & $1,93 \mathrm{~b}$ \\
\hline 156 & $9,89 a$ & $2,92 \mathrm{c}$ & $1,08 d$ & $4,27 \mathrm{~b}$ \\
\hline 234 & $11,16 \mathrm{a}$ & $4,23 \mathrm{c}$ & $2,08 d$ & $7,26 \mathrm{~b}$ \\
\hline 312 & $14,14 \mathrm{a}$ & $6,39 c$ & $4,13 d$ & 8,67 b \\
\hline 468 & $19,16 \mathrm{a}$ & $9,13 b$ & 7,27 b & $10,03 b$ \\
\hline
\end{tabular}

$\mathrm{FE}=$ Folhas emergentes; $\mathrm{LN}=$ Lâminas de folhas recém-expandidas; LM= Lâminas de folhas maduras; $\mathrm{CB}=$ Colmos+bainhas.

** Por insuficiência de material, não houve determinação do potássio no tecido vegetal. Letras diferentes nas linhas indicam diferenças significativas ao nível de $5 \%$ de probabilidade (Tukey). 
Para o segundo crescimento observou-se, também, que ocorreu um aumento nos valores da relação $\mathrm{K}: \mathrm{Mg}$ em função das doses de potássio na solução nutritiva em todos os componentes da parte aérea do Panicum maximum cv. Mombaça. Assim como no primeiro crescimento, os valores mais altos observados na relação $\mathrm{K}: \mathrm{Mg}$ foram encontrados nas folhas emergentes $\mathrm{e}$ colmos+bainhas. A maior variação entre o máximo e o mínimo valor foi verificado nos colmos+bainhas (30,4 vezes) e a menor variação foi observada nas folhas emergentes (17,6 vezes).

Segundo Malavolta et al. (1997) o valor adequado da relação K:Mg varia entre 7 e 10 na planta. Valores dessa magnitude foram encontrados nas doses de potássio de 156; 234; 312 e $468 \mathrm{mg} \mathrm{L}^{-1}$ de solução, tanto no primeiro como no segundo corte. Ainda de acordo com o mesmo autor, se a concentração absoluta de $\mathrm{Mg}$ for relativamente baixa, os sintomas de deficiência de magnésio poderão aparecer se o quociente dessa relação for da ordem de 15-20, valores estes alcançados apenas nas folhas emergentes nas doses de potássio de 312 e $468 \mathrm{mg} \mathrm{L}^{-1}$, em ambos os cortes. Porém sintomas de tal deficiência não foram observados no presente estudo.

Fonseca \& Meurer (1995), estudando a relação antagônica entre o potássio e magnésio em plantas de milho, observaram que 0 acúmulo de magnésio foi reduzido, tanto nas raízes como na parte aérea das plantas, com o aumento da concentração do potássio na solução nutritiva.

\subsubsection{Sintomas visuais de deficiência de potássio}

A sintomatologia visual de deficiência de potássio em Panicum maximum cv. Mombaça foi observada a partir dos oito dias após o transplante das mudas, com clorose na borda das folhas.

No primeiro crescimento observourse que as plantas desenvolvidas na omissão do nutriente não se desenvolveram e emitiram apenas pequenas 
folhas que apresentavam uma clorose na borda das folhas, e avançaram em direção ànervura principal em forma de um "V" invertido (Figura 21).

Por ocasião do primeiro corte, aos 30 dias após o transplante, grande parte das plantas cultivadas nos vasos em que o potássio não foi fornecido encontravam-se mortas. Também na dose de potássio de $9,75 \mathrm{mg} \mathrm{L}^{-1}$ as plantas estavam com crescimento reduzido, com colmos finos e raquíticos e as lâminas de folhas maduras exibiam uma clorose intensa, começando a secar da ponta para a base (Figura 21). Nas plantas que receberam potássio em $39 \mathrm{mg} \mathrm{L}^{-1}$ observou-se uma clorose na borda das lâminas de folhas maduras (Figura 22).

No segundo corte, aos 52 dias após transplante, foi observado que as plantas crescidas nas doses de potássio de 9,75 e $39 \mathrm{mg} \mathrm{L}^{-1}$ encontravamse com os mesmos sintomas de deficiência de potássio descritos na ocasião do primeiro corte, porém de modo mais intenso. Sintomas iniciais de carência do nutriente foram também observados na dose de potássio de $78 \mathrm{mg} \mathrm{L}^{-1}$. Além disso, constatourse que a senescência das folhas foi precoce e principalmente nas plantas que recebiam até a dose de potássio de $156 \mathrm{mg} \mathrm{L}^{-1}$.

$\mathrm{O}$ número de perfilhos e, principalmente o crescimento das plantas foram afetados em condições de deficiência de potássio. A sintomatologia de deficiência de potássio em capim-Mombaça observadas nesse estudo foi semelhante à citada por Werner (1983) e Malavolta et al. (1997), como sendo alterações características provocadas nas plantas por carência desse nutriente. França \& Haag (1985), em capim-Tobiatã, descreveram que inicialmente o desenvolvimento das plantas na omissão de potássio se procedeu de forma normal, porém após a quarta semana experimental o crescimento tornou-se lento, principalmente com relação ao tratamento completo. Verificaram que o sintoma de carência de potássio nessa gramínea forrageira se caracterizou com uma coloração ligeiramente clorótica nas pontas e ao longo das folhas, que em seguida começou a apresentar um secamento da ponta para base, com intensidade nos bordos. O perfilhamento foi reduzido nessas plantas. 

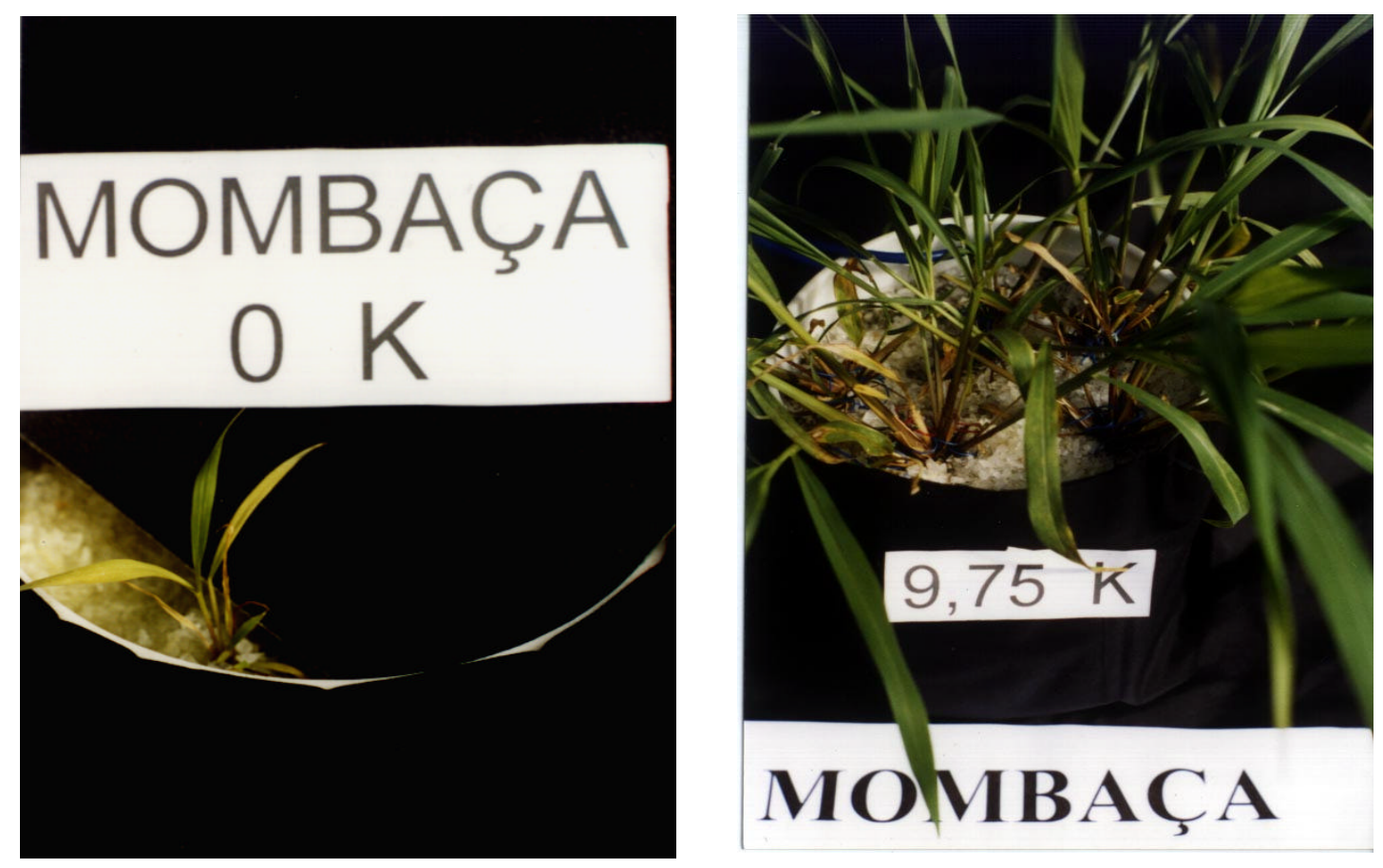

Figura 21 - Sintomas de deficiência de potássio em lâminas de folhas maduras do Panicum maximum cv. Mombaça, verificado nas doses 0 e $9,75 \mathrm{mg} \mathrm{K} \mathrm{L}^{-1}$.

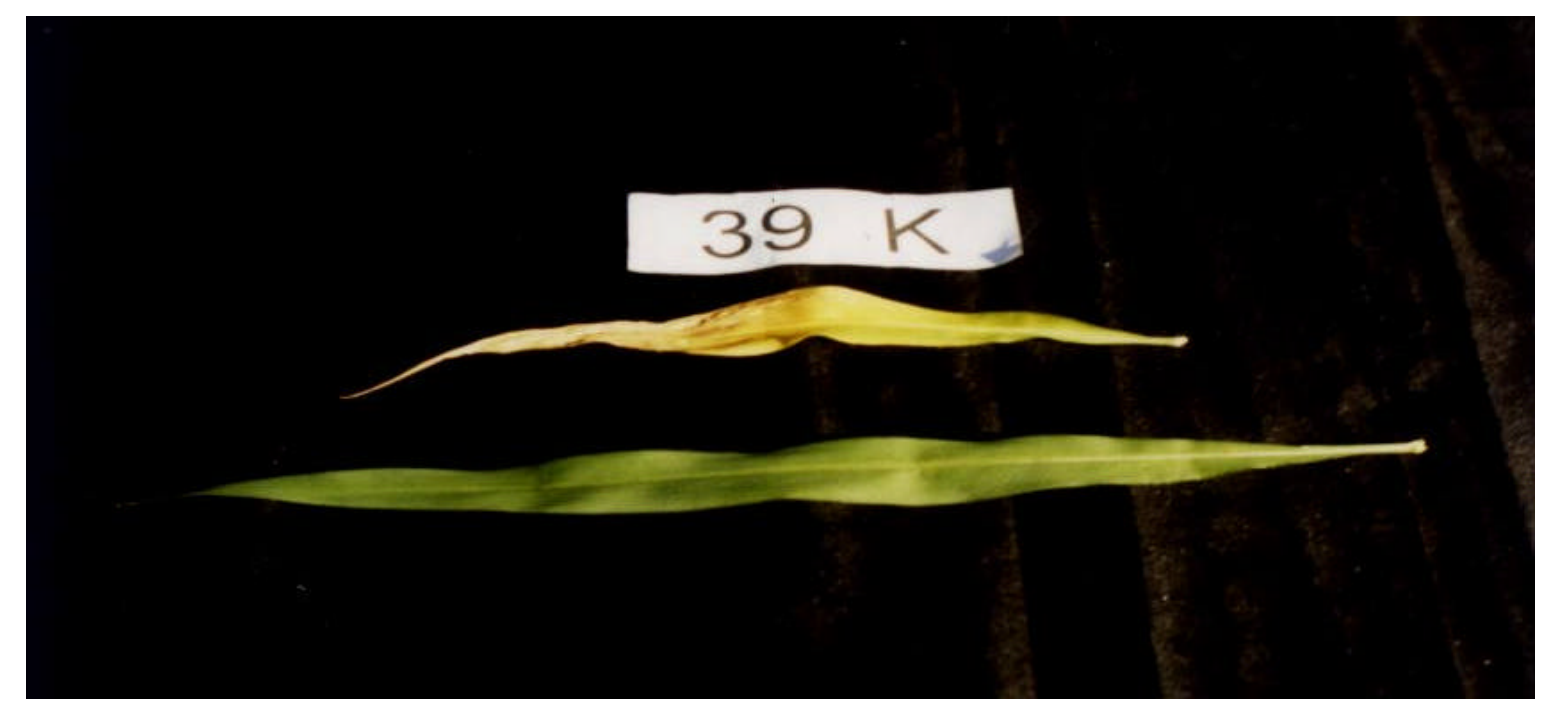

Figura 22 - llustração de lâminas de folhas maduras com deficiência de potássio no Panicum maximum cv. Mombaça, verificado na dose de potássio de $39 \mathrm{mg} \mathrm{L}^{-1}$. 


\subsection{Experimento com doses de magnésio}

\subsubsection{Produção de massa seca da parte aérea e das raízes}

A análise de variância mostrou significância $(P<0,01)$ do efeito das doses de magnésio na solução na produção de massa seca da parte aérea e das raízes, tanto no primeiro como no segundo corte do Panicum maximum cv. Mombaça.

No primeiro crescimento do capim-Mombaça, os resultados da produção de massa seca apresentaram ajuste a modelo quadrático (Figura 23). O ponto de máxima produção da parte aérea ocorreu com o magnésio na solução nutritiva em $59 \mathrm{mg} \mathrm{L}^{-1}$. Observa-se que o valor encontrado situa-se bem próximo à dose máxima utilizada neste experimento $\left(60 \mathrm{mg} \mathrm{L}^{-1}\right)$. Essa concentração de magnésio ( $59 \mathrm{mg} \mathrm{L}^{-1}$ ) é mais elevada que os $48 \mathrm{mg} \mathrm{L}^{-1}$ estabelecidos por Sarruge (1975) para o tratamento completo.

No material vegetal proveniente do segundo corte os resultados da produção de massa seca variaram de forma linear com as doses de magnésio utilizadas na solução nutritiva (Figura 24). Verificou-se que, para o capimMombaça, a concentração de $48 \mathrm{mg} \mathrm{L}^{-1}$ de magnésio na solução estabelecida no tratamento completo da solução Sarruge (1975) não foi suficiente para atender às exigências para a expressão do máximo potencial produtivo dessa gramínea.

Morikawa (1993), utilizando a técnica do elemento faltante, verificou que a omissão de magnésio não afetou a produção de massa seca da parte aérea das plantas forrageiras Andropogon e Braquiária quando comparada ao tratamento completo. Justificou esse resultado pelo fato que as gramíneas forrageiras geralmente são pouco exigentes nesse nutriente. 


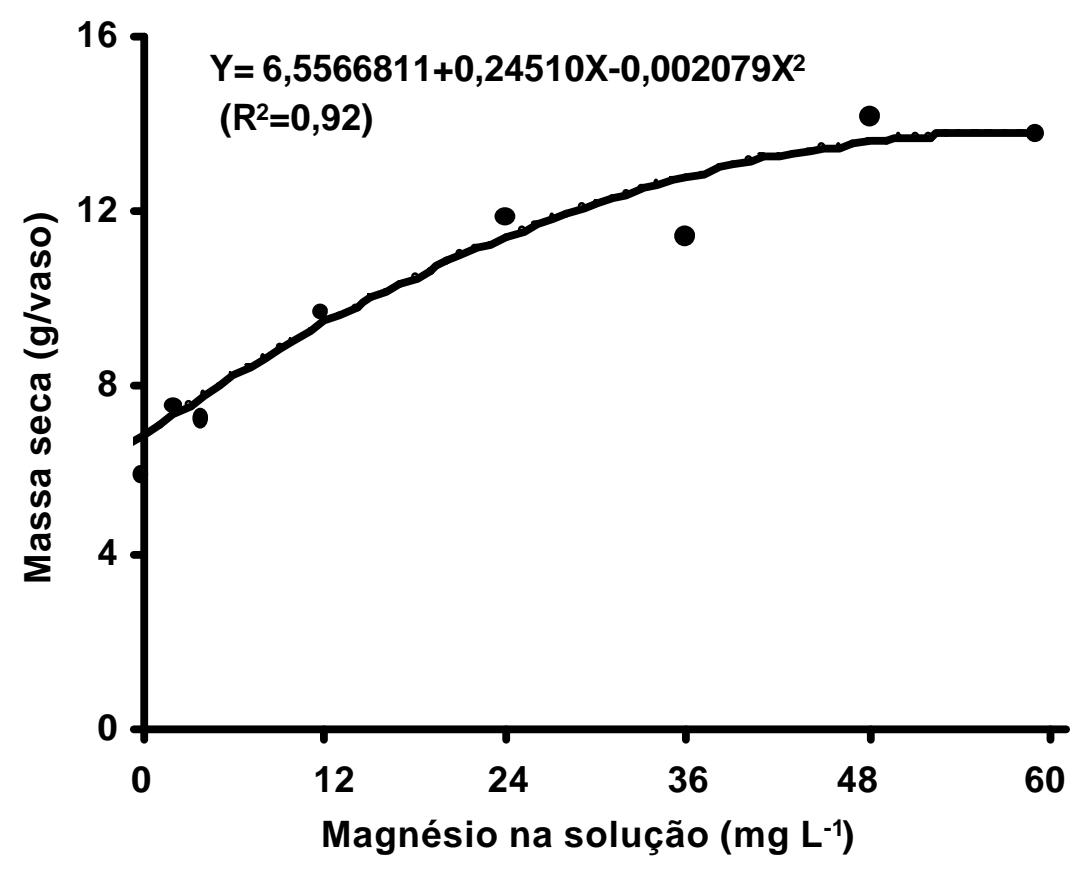

Figura 23 - Produção de massa seca da parte aérea no primeiro corte do Panicum maximum cv. Mombaça, em função das doses de magnésio.

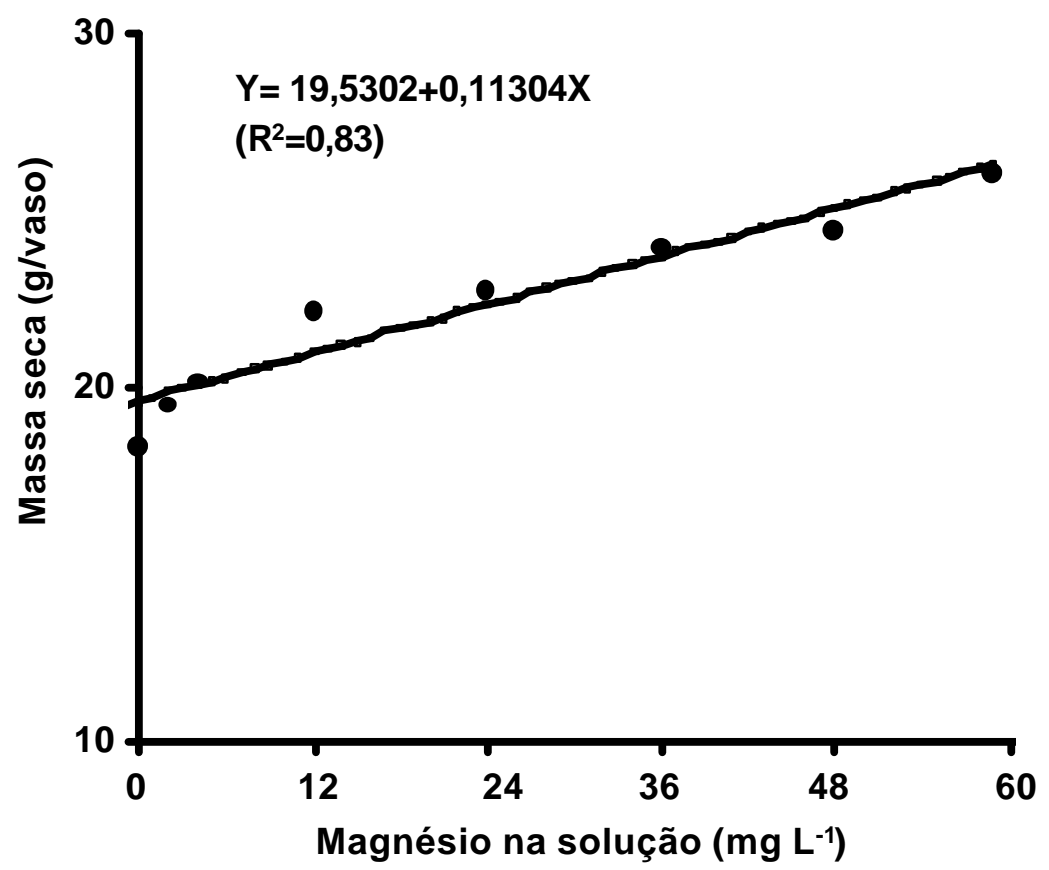

Figura 24 - Produção de massa seca da parte aérea no segundo corte do Panicum maximum cv. Mombaça, em função das doses de magnésio. 
Werner \& Haag (1972) observaram em capim-Colonião que a produção de massa seca do tratamento com omissão de magnésio não diferiu estatisticamente daquela do tratamento completo. Acrescentaram que as quantidades iniciais de magnésio fornecidas pela solução completa supriram, através da recirculação na planta, as possíveis deficiências que fossem ocorrer, evitando assim diminuição de crescimento.

Objetivando estudar o efeito das doses de magnésio, em experimento com solução nutritiva, no rendimento da massa seca em Brachiaria brizantha cv. Marandu, em dois períodos de avaliação, Sarkis et al. (1996) verificaram que o magnésio exerceu influência significativa na produção de massa seca da planta forrageira em ambos os cortes.

Os resultados de produção de massa seca de raízes do capim-Mombaça apresentaram ajuste a modelo linear (Figura 25) e, portanto, o ponto de máxima produção de massa seca das raízes nessa gramínea forrageira ocorreria em dose além do limite de magnésio utilizado na solução nutritiva. Nessa parte da planta forrageira, a produção de massa seca variou entre 1,5 vezes da condição de omissão do nutriente para a dose máxima empregada nesse experimento $\left(60 \mathrm{mg} \mathrm{L}^{-1}\right)$.

Em experimento utilizando a técnica do elemento faltante com Brachiaria brizantha cv. Marandu, Monteiro et al. (1995) constataram uma redução de $45 \%$ na produção de massa seca da parte aérea e $70 \%$ na das raízes quando omitiram o magnésio na solução nutritiva, em relação ao tratamento completo.

Trabalhando com Pennisetum purpureum cv. Napier cultivado na solução nutritiva, Haag et al. (1965) não obtiveram diminuição na produção de massa seca no tratamento em que o magnésio foi omitido, apesar da redução da concentração do elemento nas plantas. 


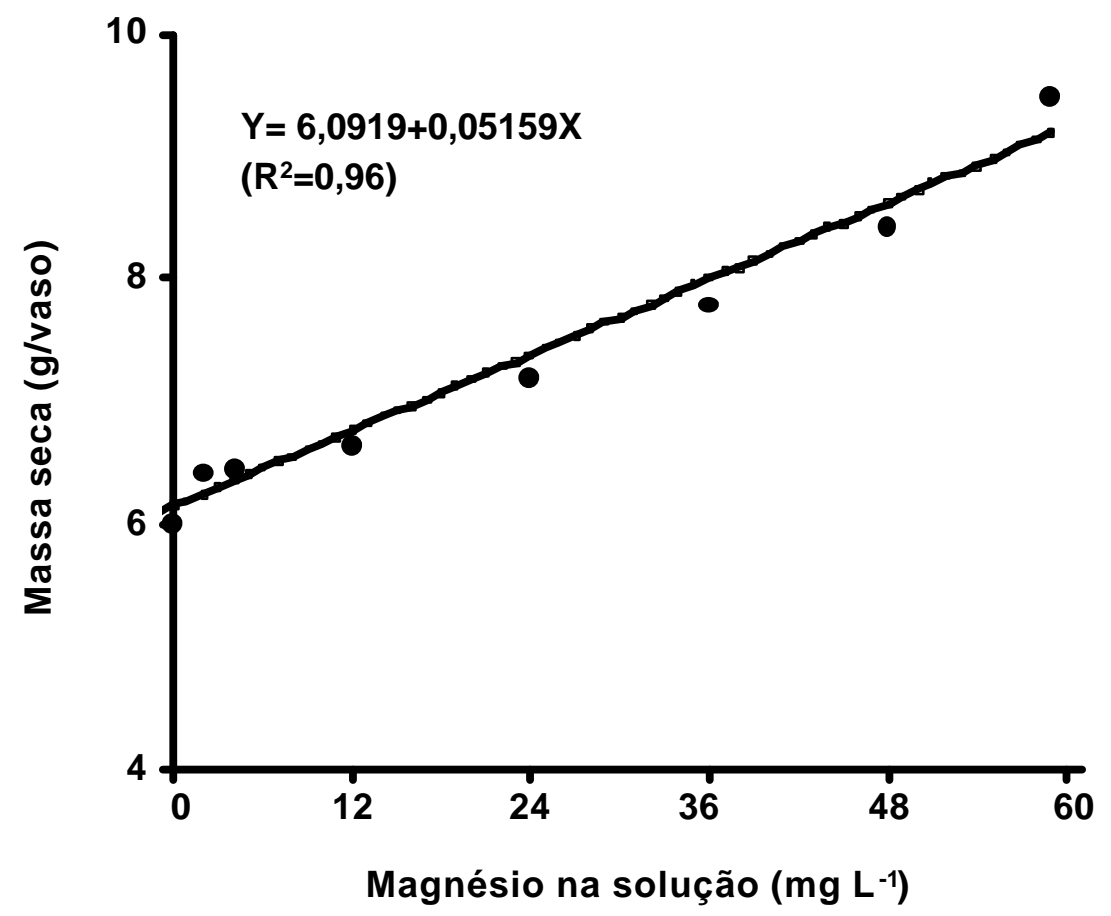

Figura 25 - Produção de massa seca das raízes do Panicum maximum cv. Mombaça, em função das doses de magnésio

A escassez de resultados publicados com referência à influência de magnésio na produção de massa seca de plantas forrageiras é fato marcante, porém ficou evidente neste experimento que o cultivar Mombaça teve sua produção de massa seca tanto da parte aérea com das raízes incrementada pelo suprimento de magnésio na solução nutritiva.

\subsubsection{Número de perfilhos}

O número de perfilhos da gramínea forrageira, em ambos os crescimentos, foi significativamente $(P<0,05)$ alterado pelas doses de magnésio na solução. Resultados semelhantes foram encontrados por Monteiro et al. (1995), que relataram uma redução de $32 \%$ no número de perfilhos na 
Brachiaria brizantha cv. Marandu no tratamento com omissão de magnésio, em relação ao completo.

No primeiro crescimento, o número de perfilhos na ausência do suprimento de magnésio não diferiu estatisticamente da dose de magnésio de $1,2 \mathrm{mg} \mathrm{L}^{-1}$ na solução, assim como as doses 1,2; 3,6 e $12 \mathrm{mg} \mathrm{L}^{-1}$ não demonstraram diferenças significativas entre si. Porém, o número de perfilhos nas doses 48 e $60 \mathrm{mg} \mathrm{L}^{-1}$ diferiu significativamente daquele nas demais doses de magnésio (Figura 26).

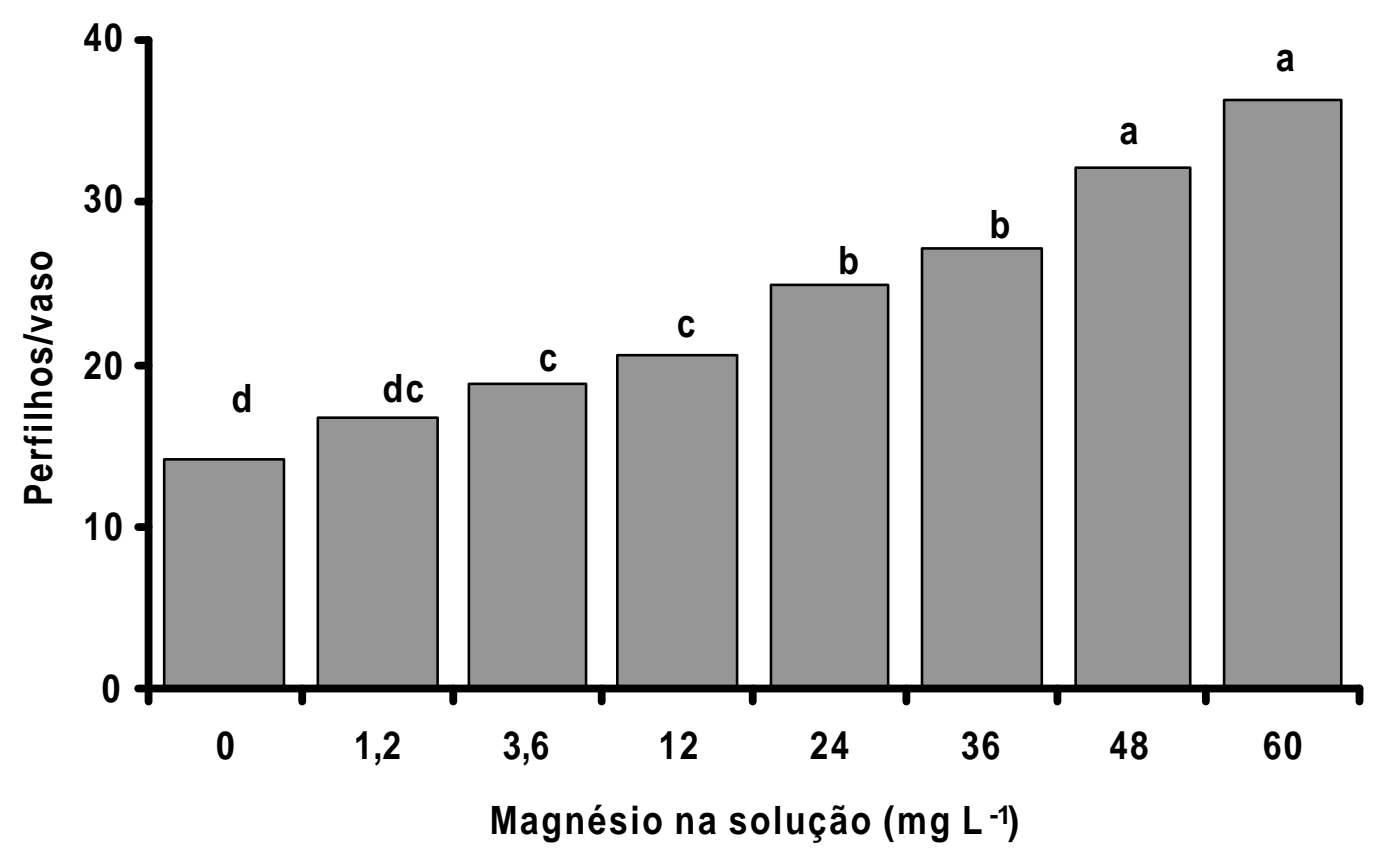

Figura 26 - Número de perfilhos nas cinco plantas do Panicum maximum cv. Mombaça, no primeiro corte, em função das doses de magnésio na solução nutritiva. Letras diferentes indicam diferenças significativa ao nível de $5 \%$ de probabilidade (Tukey). 
Para o segundo crescimento, o número de perfilhos não variou significativamente entre as doses de magnésio de $0 ; 1,2$ e $3,6 \mathrm{mg} \mathrm{L}^{-1}$. $\mathrm{O}$ mesmo ocorreu quando se compararam entre si as doses de 12; 24 e 36; de 36 e 48 e de 48 e $60 \mathrm{mg} \mathrm{L}^{-1}$ (Figura 27).

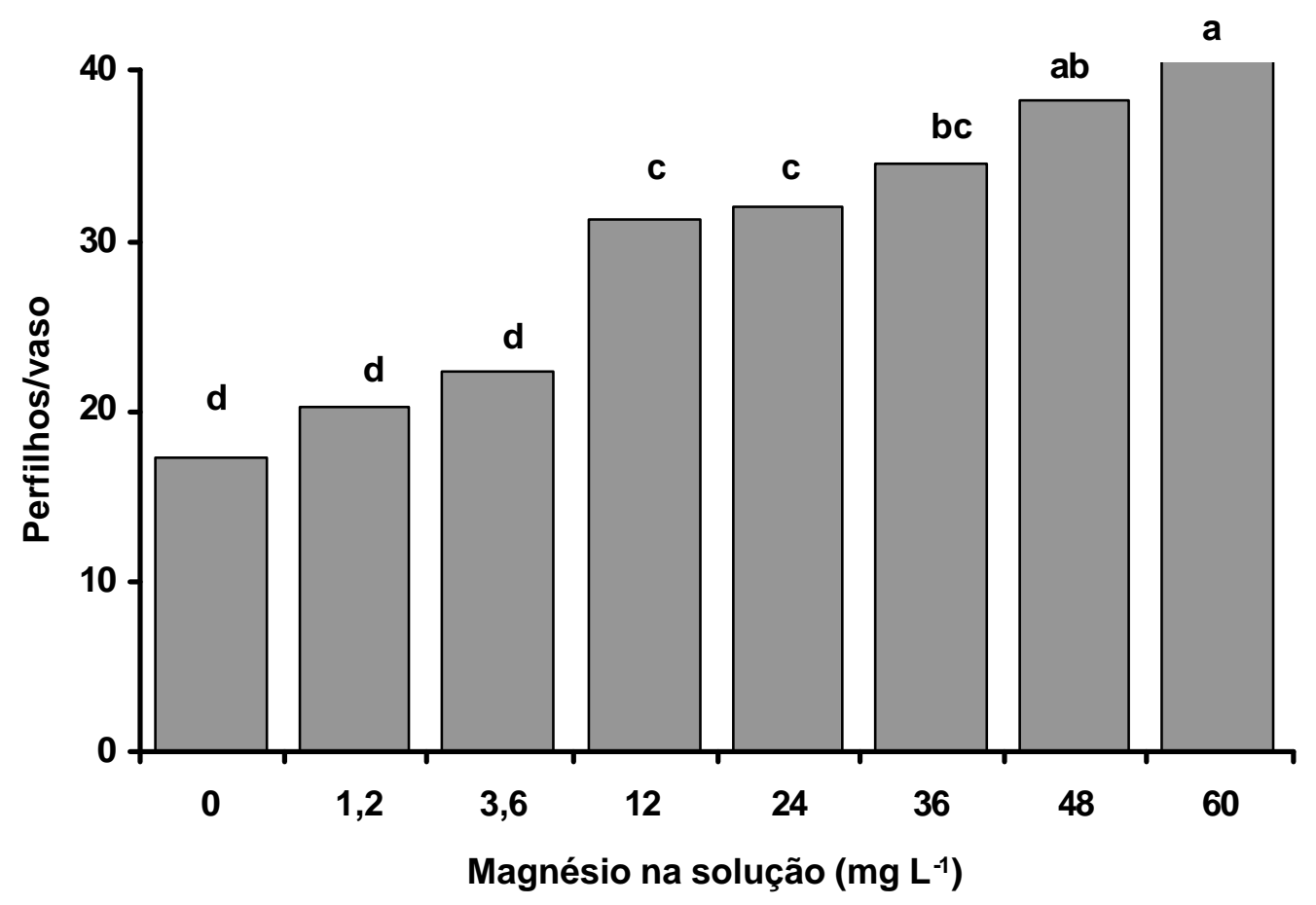

Figura 27 - Número de perfilhos nas cinco plantas do Panicum maximum cv. Mombaça, no segundo corte, em função das doses de magnésio na solução nutritiva. Letras diferentes indicam diferenças significativa ao nível de $5 \%$ de probabilidade (Tukey).

Entretanto, observa-se um aumento no número de perfilhos em função do incremento das doses de magnésio na solução no capim-Mombaça, em ambos os crescimentos. As doses de magnésio de 48 e $60 \mathrm{mg} \mathrm{L}^{-1}$ foram as responsáveis pelo maior número de perfilhos, em ambas as épocas. O número 
médio de perfilhos no primeiro crescimento foi menor que no segundo, provavelmente devido ao fato que na primeira fase do experimento a planta estar em estabelecimento e em formação do sistema radicular, enquanto que na segunda fase o sistema radicular já estava formado, o que certamente facilitou o perfilhamento. A permanência de gemas por ocasião do primeiro corte (cerca de 1 a 3 por perfilho), que foram mantidas por ocasião do segundo crescimento deve, provavelmente, ter proporcionado maior aparecimento dos perfilhos.

\subsection{3 Área foliar}

Os resultados das medidas de área foliar do Panicum maximum cv. Mombaça em função das doses de magnésio, são mostrados nas Figuras 28 e 29. Verifica-se que, em ambos os crescimentos, os valores de área foliar foram significativamente $(P<0,01)$ influenciados pelas doses de magnésio na solução e ajustaram-se a modelo linear. As medidas da área foliar podem assumir valores mais elevados se forem empregadas doses superiores æ̀ avaliadas neste experimento.

As medidas de área foliar do capim-Mombaça em função das doses de magnésio estiveram entre 1434,71 a 2950,74 cm²/vaso e 1974,02 a $2765,32 \mathrm{~cm}^{2} /$ vaso no primeiro e no segundo crescimentos, respectivamente.

Meiri et al. (1992), em estudo de avaliação do crescimento e deposição do magnésio nas folhas de milho, observaram que elevadas concentrações deste nutriente nas células em divisão permitiram altas taxas de síntese proteíca e polimerização do RNA e estiveram associadas ao maior crescimento e expansão foliar. 


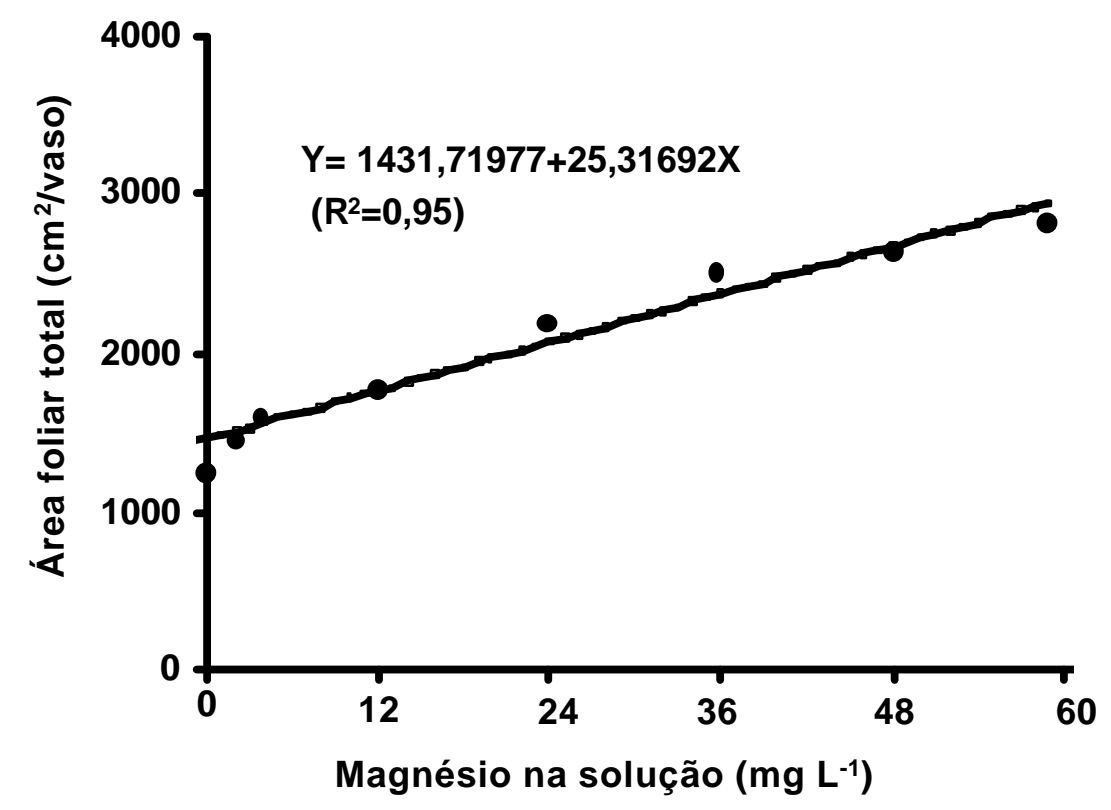

Figura 28 - Área foliar por ocasião do primeiro corte do Panicum maximum cv. Mombaça, em função das doses de magnésio na solução.

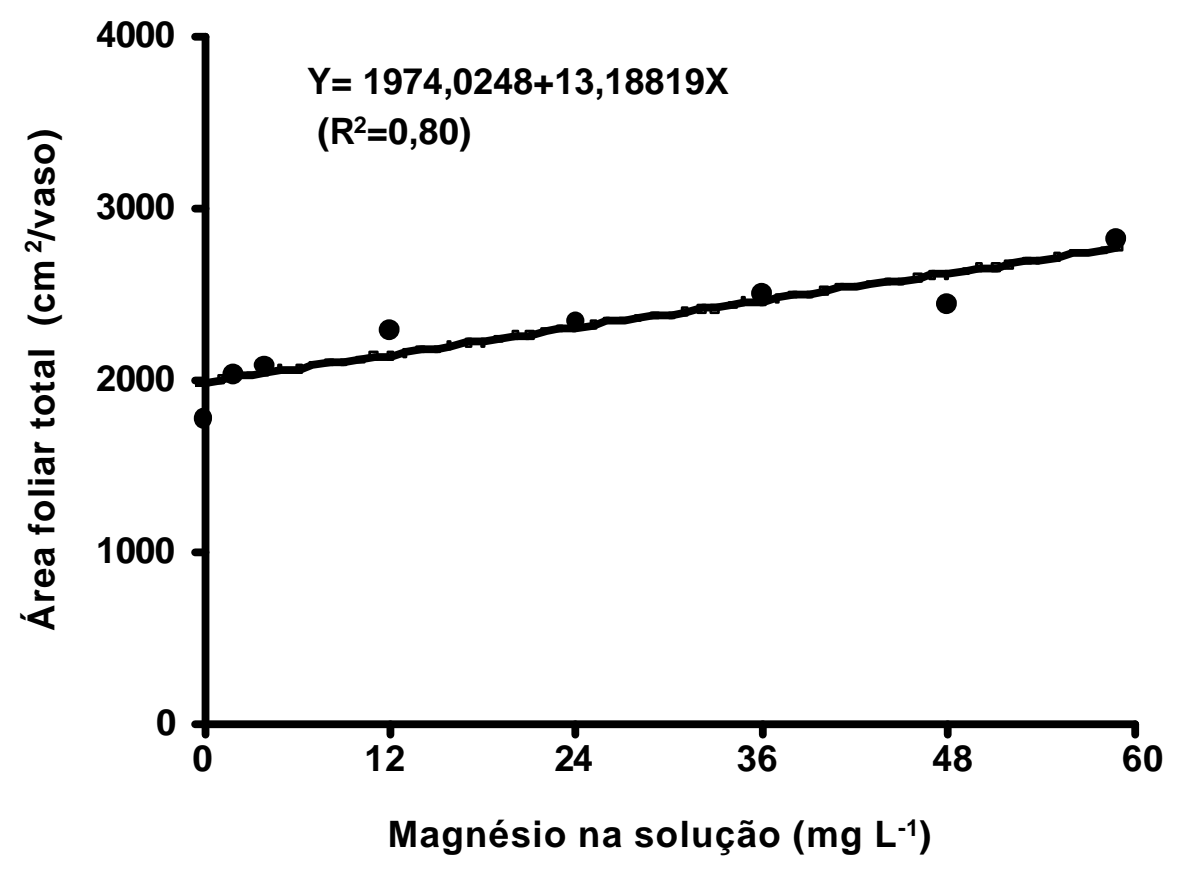

Figura 29 - Área foliar por ocasião do segundo corte do Panicum maximum cv. Mombaça, em função das doses de magnésio na solução. 


\subsubsection{Estimativa do teor de clorofila em valor SPAD}

No primeiro crescimento do capim-Mombaça constatou-se que a estimativa do teor de clorofila, pelo valor SPAD nas lâminas folhas recémexpandidas, apresentou variação significativa $(P<0,01)$ com as doses de magnésio na solução (Figura 30). Observa-se que os valores SPAD ajustaramse a modelo quadrático e o ponto de máximo valor foi obtido na dose de magnésio de $40 \mathrm{mg} \mathrm{L}^{-1}$, que resultou em 41,8 unidades de valor SPAD.

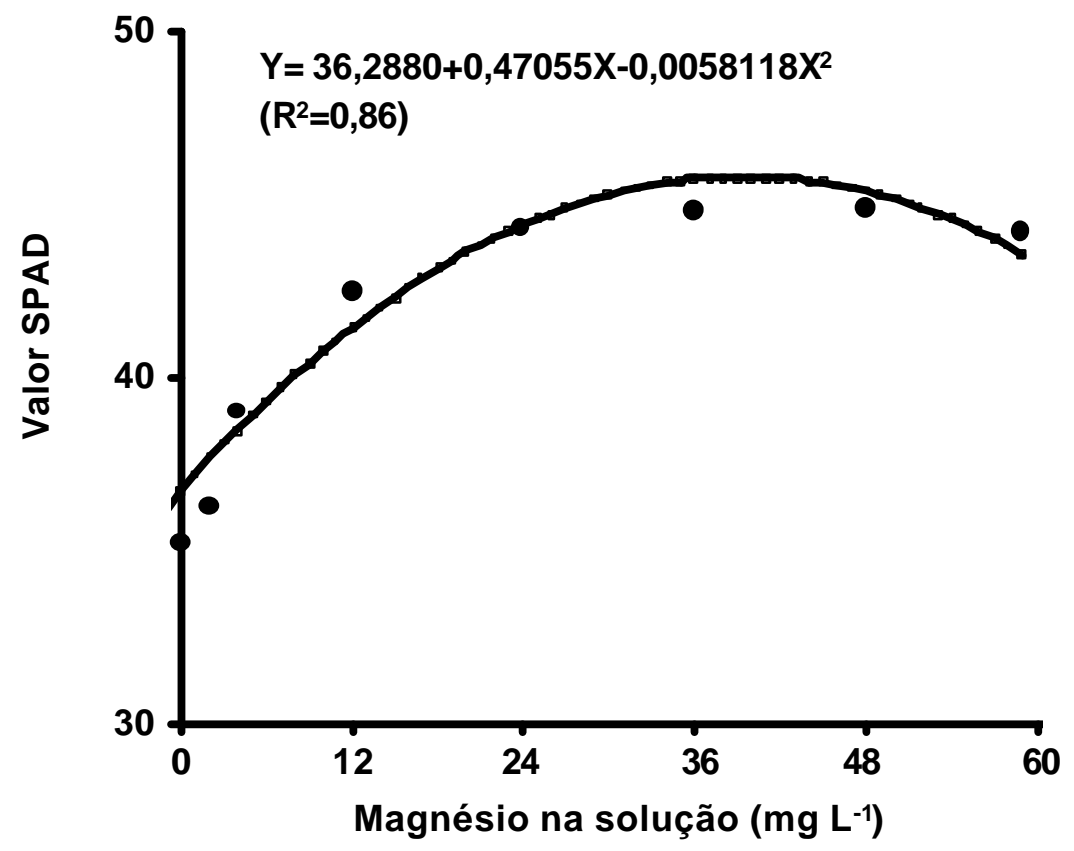

Figura 30 - Teor de clorofila determinado em unidades de valor SPAD no primeiro corte do Panicum maximum cv. Mombaça, em função das doses de magnésio na solução.

Para o segundo crescimento foi verificado que os resultados de unidades de valor SPAD, nas lâminas de folhas recém-expandidas da planta forrageira, foram significativamente $(P<0,0,1)$ influenciados pelo incremento de magnésio na solução e apresentaram ajustes a modelo quadrático (Figura 31). Constatourse também que a dose de magnésio de $47 \mathrm{mg} \mathrm{L}^{-1}$ de solução foi a 
que proporcionou o máximo teor de clorofila, representado por 33,4 unidades de valor SPAD. A variação dos valores SPAD referentes aos teores de clorofila na lâmina foliar, em função das doses de magnésio entre a condição de omissão do nutriente na solução e a dose referente ao máximo teor de clorofila foi próxima a $21 \%$.

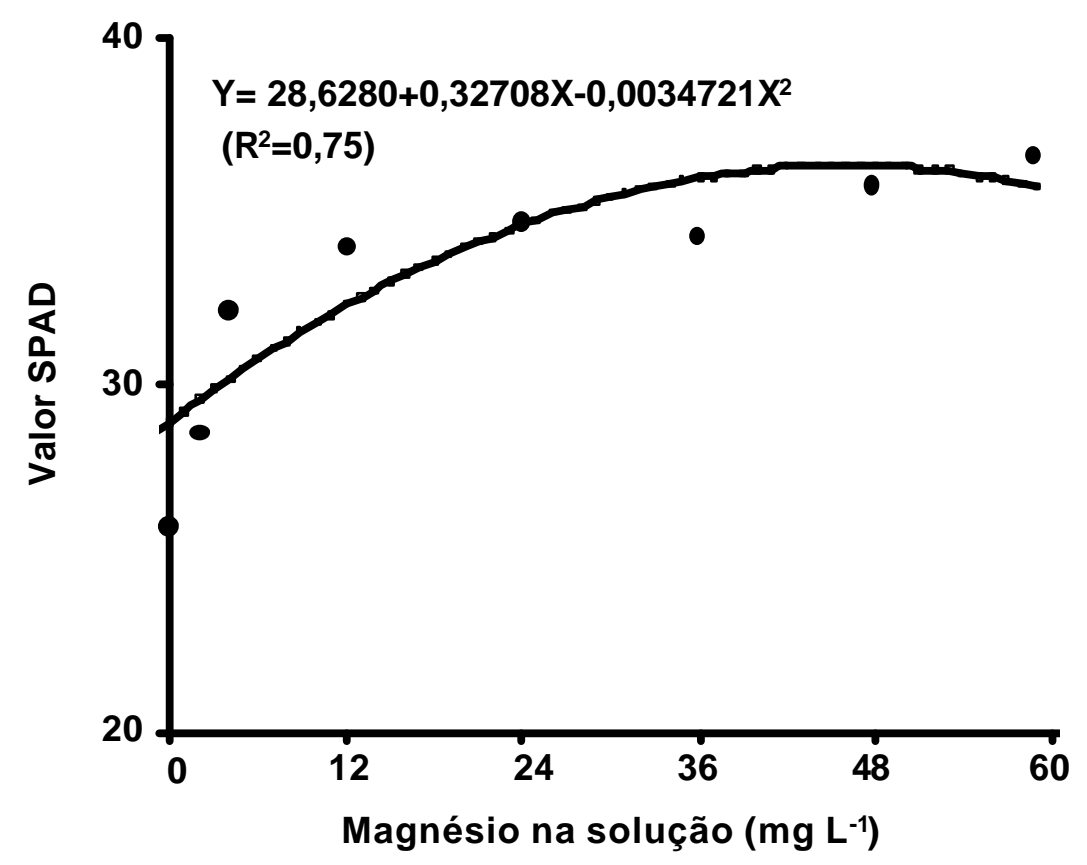

Figura 31 - Teor de clorofila determinado em unidade de valor SPAD no segundo corte do Panicum maximum cv. Mombaça, em função das doses de magnésio na solução.

Analisando os resultados pode-se observar que, em função das doses de magnésio na solução, as leituras do clorofilômetro no segundo crescimento (33,4 unidades) foram inferiores à verificadas no primeiro crescimento $(41,8$ unidades) do capim-Mombaça. Esse fato pode ser justificado pelo efeito diluição do nutriente, pois no segundo ciclo vegetativo ocorreu maior produção de material vegetal o que consequentemente proporcionou uma diminuição da concentração de clorofila na lâmina foliar. 
Almeida (1998), em estudo com combinação de doses de fósforo e de magnésio para o capim-Braquiária, constatou aos 25 dias após o transplante das plântulas, que o teor de clorofila em lâmina foliares mais velhas e que ainda permaneciam verdes esteve relacionado linearmente com o fornecimento de magnésio na solução. Porém, nas avaliações realizadas aos 35 dias após transplante e aos 18 dias após o primeiro corte, não foram detectadas variações significativas no teor de clorofila nas lâminas foliares da braquiária, em função das doses de magnésio.

\subsubsection{Concentração de magnésio nos tecidos vegetais}

\subsubsection{Folhas emergentes}

A análise de variância revelou que houve significância $(P<0,01)$ das doses de magnésio na solução nutritiva na concentração de magnésio em folhas emergentes (FE) na planta forrageira, tanto por ocasião do primeiro como no segundo corte das plantas. Os resultados referentes ao primeiro crescimento demonstraram ajustes a modelo linear (Figura 32), o que caracteriza potencialidade de aumento nessa concentração com o suprimento de doses de magnésio na solução mais elevadas que as utilizadas nesse estudo. Nesse corte, a concentração de magnésio variou entre 0,75 e de $3,94 \mathrm{~g} \mathrm{~kg}^{-1}$, respectivamente, para a menor e maior dose de magnésio aplicada no experimento. 


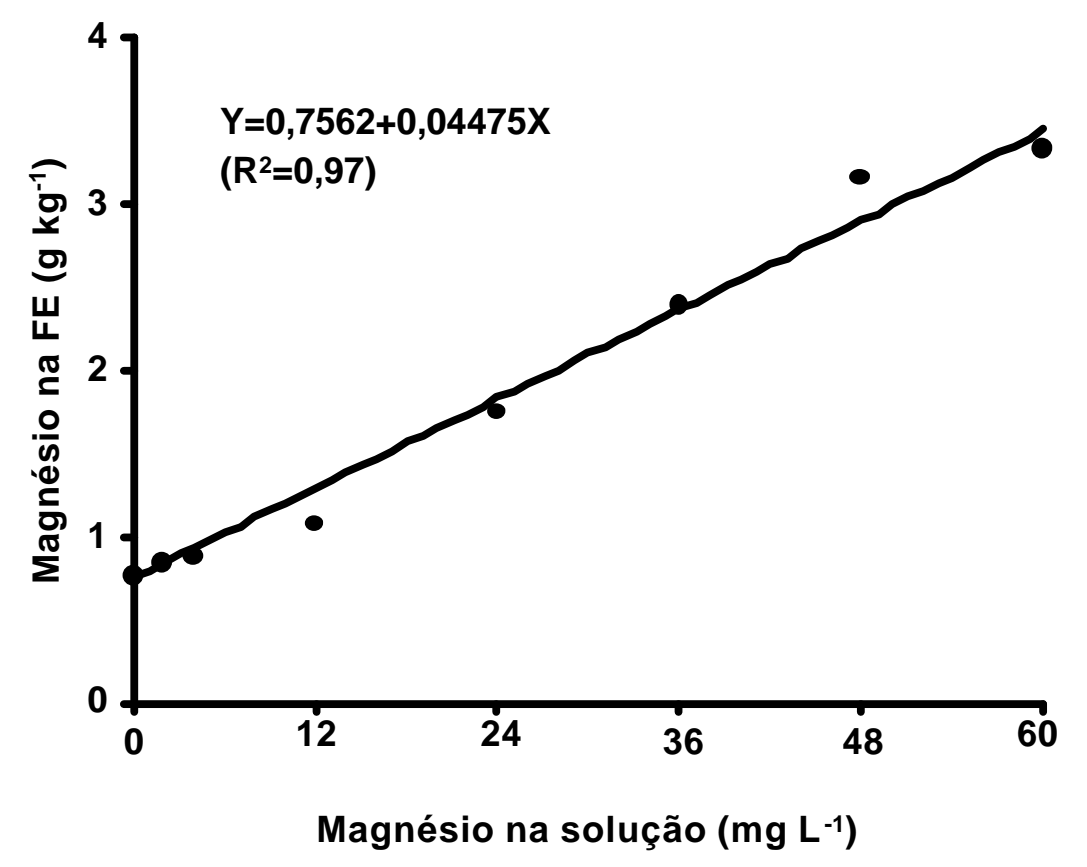

Figura 32 - Concentração de magnésio nas folhas emergentes no primeiro corte do Panicum maximum cv. Mombaça, em função das doses de magnésio na solução.

No material coletado no segundo corte a concentração de magnésio também variou segundo uma equação de primeiro grau (Figura 33) com as doses de magnésio na solução nutritiva. Assim como no primeiro crescimento das plantas os resultados demonstraram que o ponto de máxima concentração do nutriente na solução nas folhas emergentes ocorreria além da mais elevada dose estudada. A concentração de magnésio nessa parte da gramínea, no segundo corte, variou entre $0,55 \mathrm{~g} \mathrm{~kg}^{-1}$ na ausência do nutriente na solução e $1,89 \mathrm{~g} \mathrm{~kg}^{-1}$ para a mais elevada dose utilizada. 


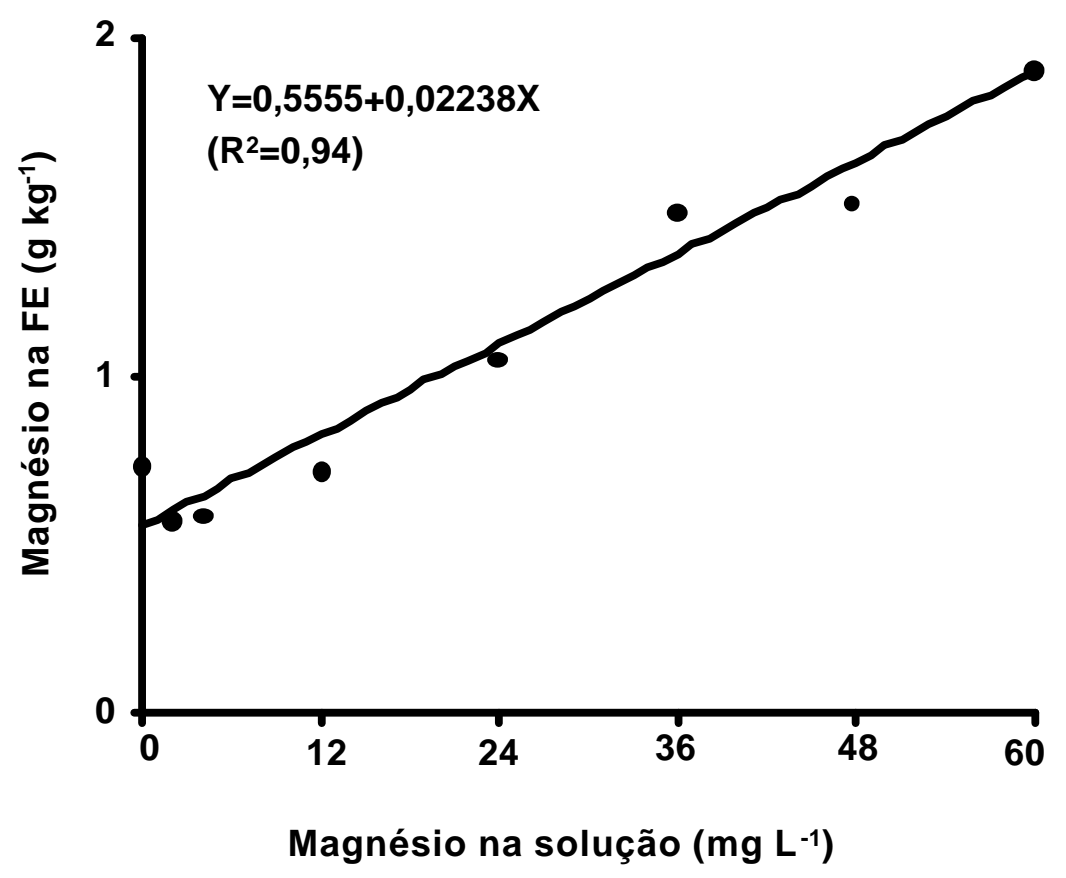

Figura 33 - Concentração de magnésio nas folhas emergentes no segundo corte do Panicum maximum cv. Mombaça, em função das doses de magnésio na solução.

\subsubsection{Lâminas de lâminas folhas recém-expandidas}

A concentração de magnésio nas lâminas de folhas recém-expandidas (LN) variou significativamente $(P<0,01) \mathrm{com}$ as doses de magnésio na solução nutritiva, ajustando-se tanto no primeiro e como segundo crescimento a modelos lineares.

No primeiro crescimento da gramínea, a concentração de magnésio no material vegetal foi aumentada pelas doses de magnésio na solução nutritiva (Figura 34). A concentração de magnésio nessa parte da planta variou entre os valores extremos de 0,48 a $6,67 \mathrm{~g} \mathrm{~kg}^{-1}$. 


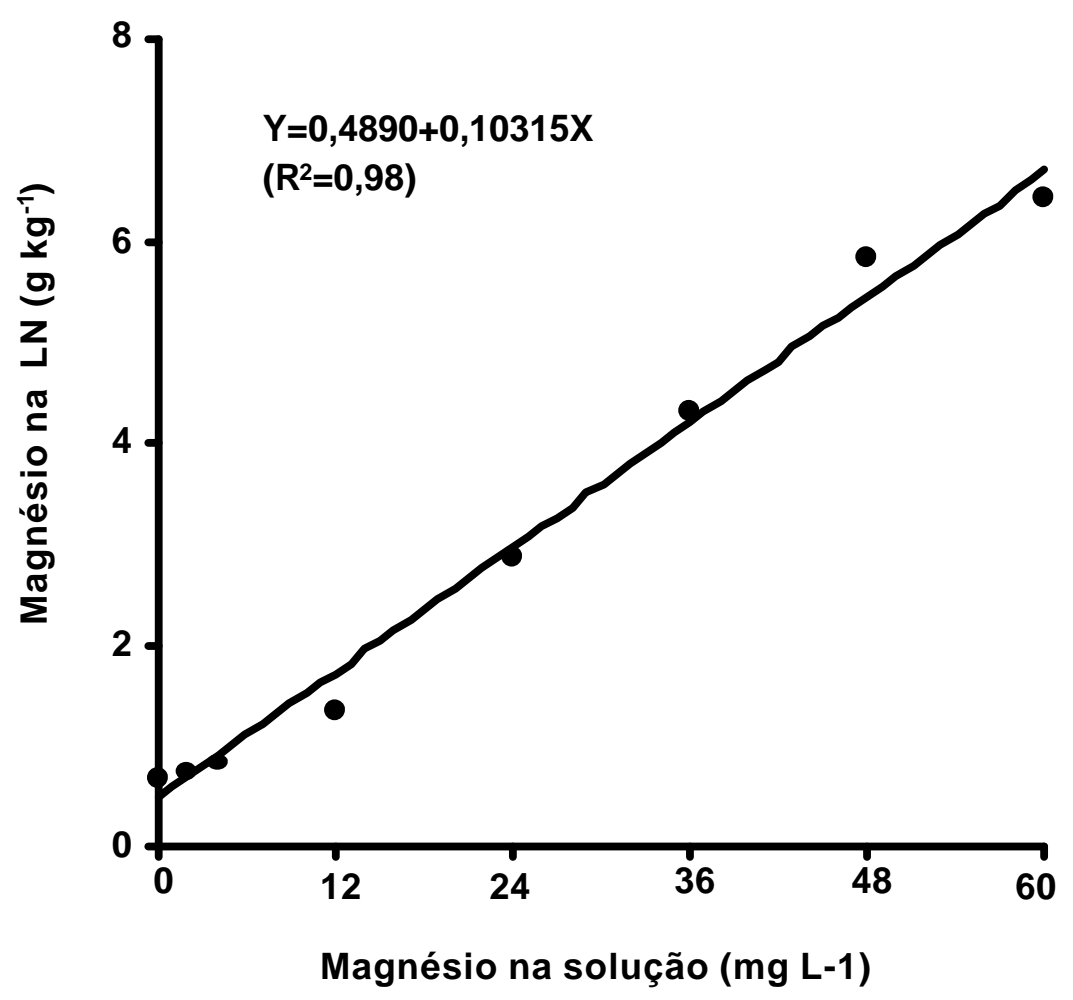

Figura 34 - Concentração de magnésio nas lâminas de folhas recém-expandidas no primeiro corte do Panicum maximum cv. Mombaça, em função das doses de magnésio na solução.

Observa-se, na Figura 35, que na amostragem à época do segundo corte as concentrações de magnésio nas folhas emergentes do capim-Mombaça estiveram entre $0,24 \mathrm{~g} \mathrm{~kg}^{-1}$ (quando na ausência de magnésio) e $3,80 \mathrm{~g} \mathrm{~kg}^{-1}$ (para a dose máxima de $60 \mathrm{mg} \mathrm{L}^{-1}$ ).

Truzzi et al. (1995), verificando o efeito das interações entre a absorção do potássio e magnésio em plantas de milho, constataram que a concentração de magnésio na parte nova das plantas aumentou de forma linear com o incremento das doses de magnésio (16; 48 e $80 \mathrm{mg} \mathrm{L}^{-1}$ ) na solução nutritiva, em presença de qualquer das doses de potássio $(78 ; 124 \mathrm{e}$ $390 \mathrm{mg} \mathrm{L}^{-1}$ ) na solução, tendo os maiores incrementos ocorrido dentro da dose $78 \mathrm{mg} \mathrm{L}^{-1}$ de potássio. 


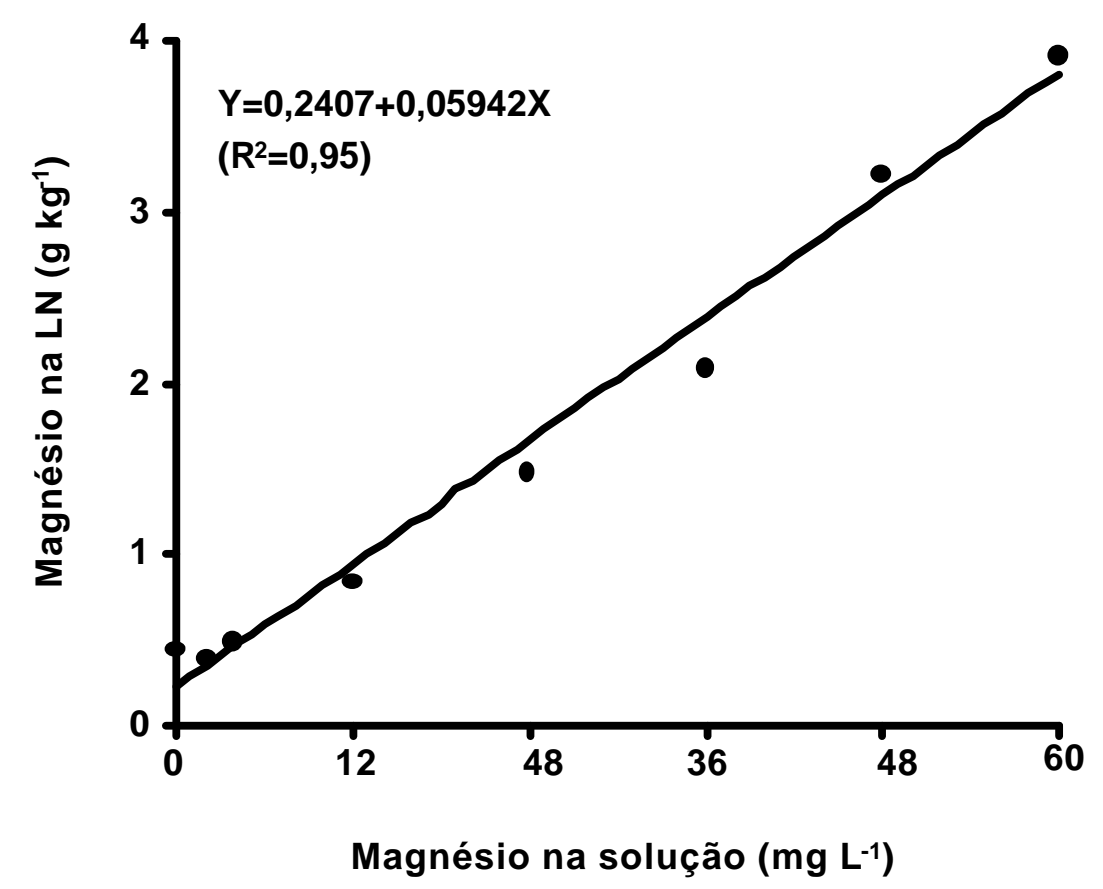

Figura 35- Concentração de magnésio nas lâminas de folhas recém-expandidas no segundo corte do Panicum maximum cv. Mombaça, em função das doses de magnésio na solução.

\subsubsection{Lâminas de folhas maduras}

Os resultados do primeiro corte das plantas mostraram que a concentração de magnésio nas lâminas de folhas maduras (LM) da espécie Panicum maximum cv. Mombaça sofreu incremento significativo $(P<0,01) \mathrm{com}$ a doses de magnésio na solução nutritiva. No material amostrado nesse crescimento, observou-se que as concentrações de magnésio nas lâminas de folhas maduras foram incrementadas linearmente (Figura 36) em função das doses do nutriente no substrato.

No segundo crescimento, a concentração de magnésio em lâminas de folhas maduras no capim-Mombaça mostrou resposta significativa $(P<0,01)$ æ̀ doses de magnésio presentes na solução nutritiva. Os resultados também 
apresentaram ajuste a modelo linear (Figura 37). A variação da concentração de magnésio nas lâminas de folhas maduras foi de 0,23 a 12,9 e de 0,057 a $8,69 \mathrm{~g} \mathrm{~kg}^{-1}$ de massa seca, nos limites das doses estudadas, para a época do primeiro e segundo cortes da planta forrageira, respectivamente.

Almeida (1998) verificou que a concentração de magnésio nas lâminas foliares da Brachiaria decumbens e da Brachiaria brizantha cv. Marandu aumentou consideravelmente à medida em que se elevaram as doses de magnésio na solução. Do mesmo modo, Marun (1990) e Premazzi (1991) também detectaram elevação na concentração do magnésio, quando aumentaram a disponibilidade desse nutriente no substrato.

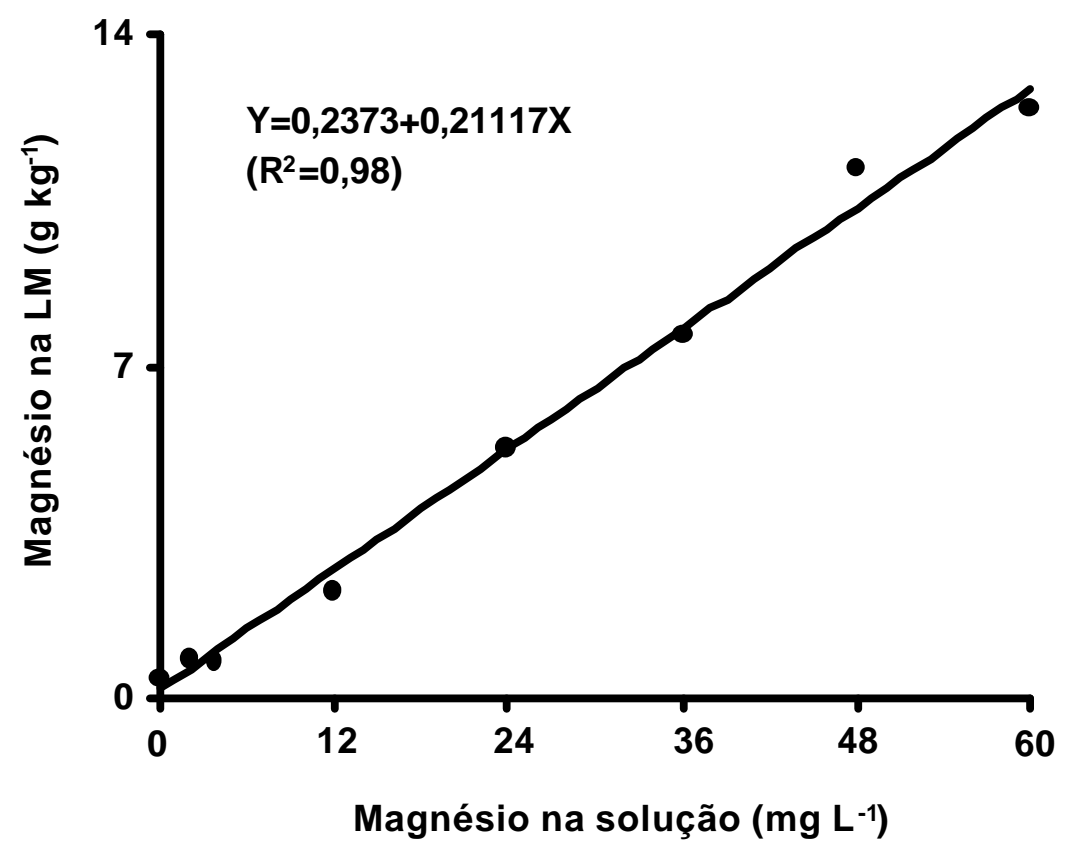

Figura 36 - Concentração de magnésio nas lâminas de folhas maduras no primeiro corte do Panicum maximum cv. Mombaça, em função das doses de magnésio na solução. 


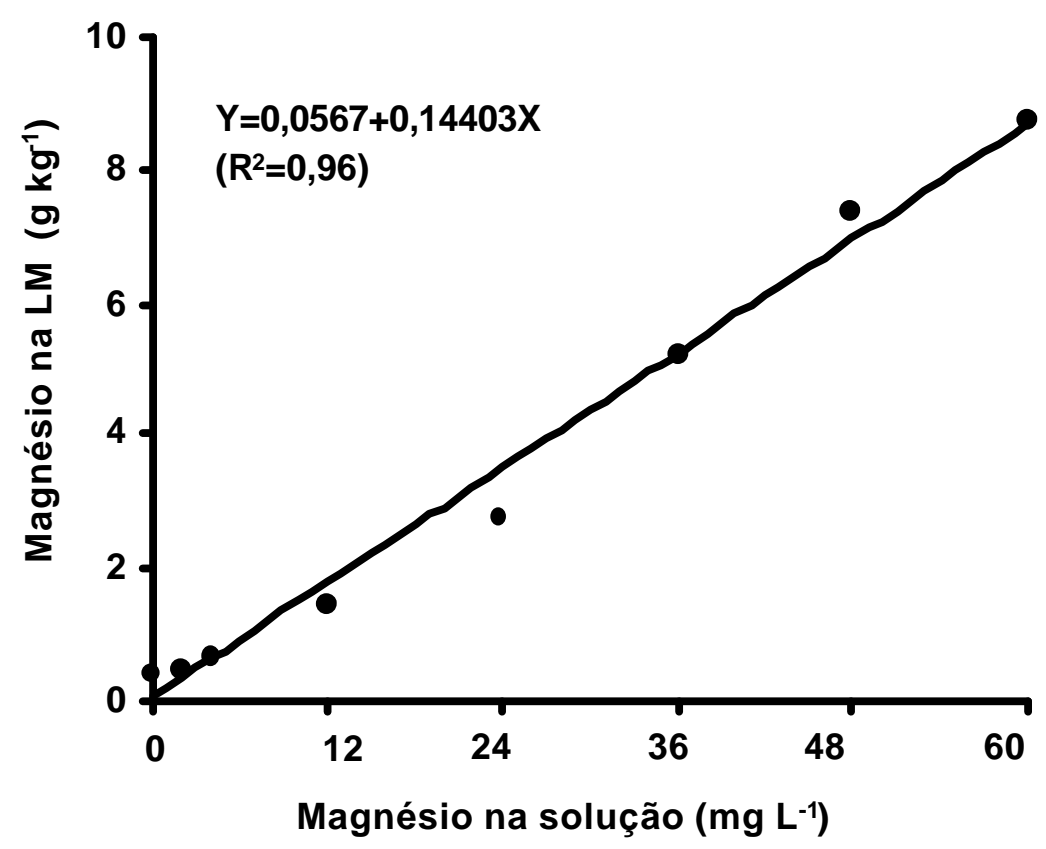

Figura 37 - Concentração de magnésio nas lâminas de folhas maduras no segundo corte do Panicum maximum cv. Mombaça, em função das doses de magnésio na solução.

\subsubsection{Colmos mais bainhas}

Verificaram-se efeitos significativos $(P<0,01)$ das doses de magnésio na concentração desse nutriente nos colmos mais bainhas do capim-Mombaça, em ambos os cortes realizados.

Os resultados referentes ao primeiro e segundo crescimentos revelaram ajustes a modelo de primeiro grau (Figuras 38 e 39) para os colmos mais bainhas da planta, o que caracteriza potencialidade de aumento da concentração desse nutriente com o fornecimento de doses mais elevadas que as utilizadas neste estudo. 


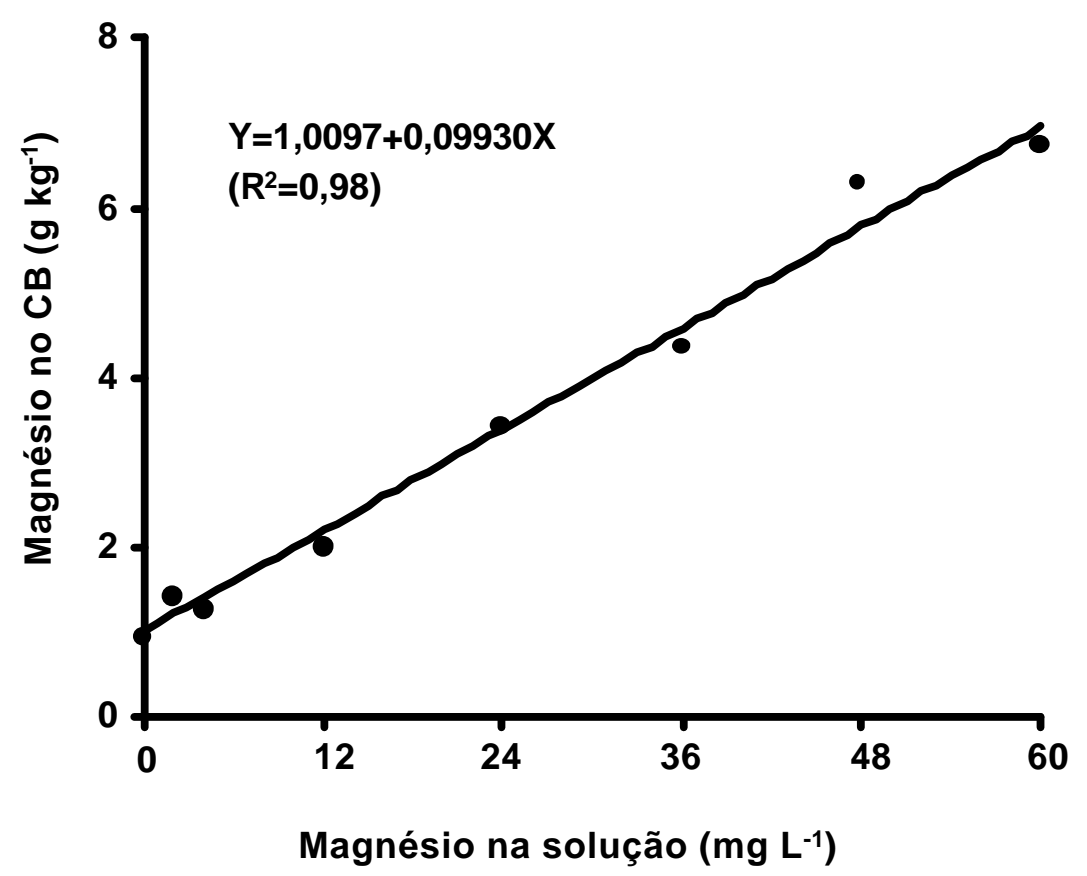

Figura 38 - Concentração de magnésio nos colmos+bainhas no primeiro corte do Panicum maximum cv. Mombaça, em função das doses de magnésio na solução.

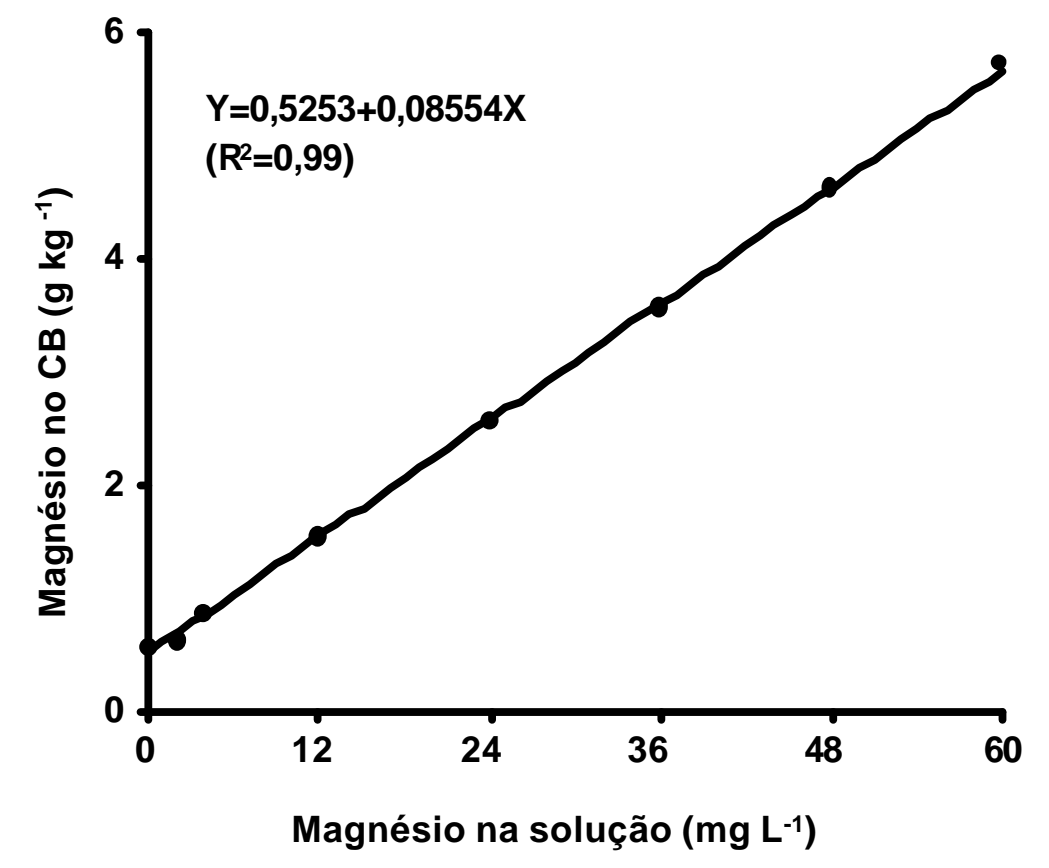

Figura 39 - Concentração de magnésio nos colmos+bainhas no segundo corte do Panicum maximum cv. Mombaça, em função das doses de magnésio na solução. 
Nos colmos mais bainhas do capim-Mombaça a concentração de magnésio esteve entre 1,0 e $6,96 \mathrm{~g} \mathrm{~kg}^{-1}$ no primeiro corte e de 0,52 a $5,65 \mathrm{~g} \mathrm{~kg}^{-1}$ no segundo corte das plantas. Também, Almeida (1998) em capimBraquiária observou que a elevação da concentração de magnésio na solução nutritiva, no primeiro crescimento, resultou em um incremento linear na concentração de magnésio nos colmos+bainhas variando de 1,2 a $3,72 \mathrm{~g} \mathrm{~kg}^{-1}$ para as doses de 4,8 e $48 \mathrm{mg} \mathrm{L}^{-1}$, respectivamente.

\subsubsection{Raízes}

A concentração de magnésio nas raízes do Panicum maximum cv. Mombaça foi significativamente $(P<0,01)$ influenciada pelas doses de magnésio na solução nutritiva. Essa concentração variou segundo uma equação do primeiro grau em função das doses de magnésio utilizadas na solução nutritiva (Figura 40).

Nas raízes do capim-Mombaça a concentração de magnésio variou entre 0,34 a $1,62 \mathrm{~g} \mathrm{~kg}^{-1}$. Foi possível observar que a concentração de magnésio nas raízes foi mais baixa que a encontrada nas folhas emergentes, nas lâminas de folhas récem-expandidas, nas lâminas de folhas maduras e nos colmos mais bainhas. 


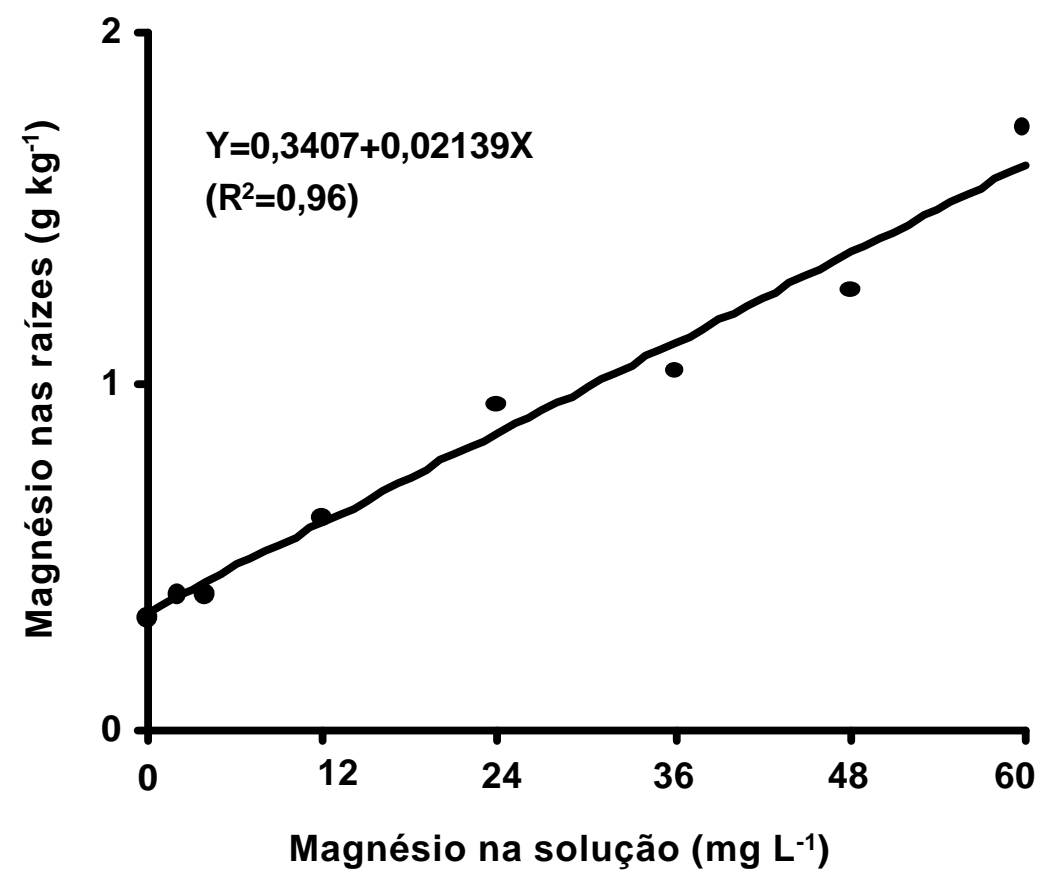

Figura 40 - Concentração de magnésio nas raízes do Panicum maximum cv. Mombaça, em função das doses de magnésio na solução.

\subsubsection{Acúmulo de magnésio nos componentes da planta}

A análise de variância mostrou significância $(P<0,01)$ das doses de magnésio para a quantidade acumulada de magnésio nos componentes da parte aérea da planta. As equações de regressão referentes ao acúmulo de magnésio nos componentes do Panicum maximum cv. Mombaça, no primeiro e segundo crescimentos, em função das doses de magnésio na solução são mostradas na Tabela 6. 
Tabela 6. Equações de regressão referentes ao acúmulo de magnésio nos componentes do Panicum maximum cv. Mombaça, no primeiro e segundo crescimentos, em função das doses de magnésio na solução.

\begin{tabular}{|c|c|c|}
\hline Parte da planta & Equação & $\mathrm{R}^{2}$ \\
\hline \multicolumn{3}{|c|}{ Primeiro corte } \\
\hline Folhas emergentes & $Y=0,3228+0,14133 X$ & 0,93 \\
\hline $\begin{array}{l}\text { Lâminas de folhas recém- } \\
\text { expandidas }\end{array}$ & $Y=0,2621+0,56963 X$ & 0,97 \\
\hline Lâminas de folhas maduras & $Y=-0,3756+0,39990 X$ & 0,98 \\
\hline Colmos+bainhas & $Y=1,6377+0,44576 X$ & 0,97 \\
\hline Parte aérea & $Y=1,8459+1,55657 X$ & 0,98 \\
\hline \multicolumn{3}{|c|}{ Segundo corte } \\
\hline Folhas emergentes & $Y=1,1560+0,08294 X$ & 0,92 \\
\hline $\begin{array}{l}\text { Lâminas de folhas recém- } \\
\text { expandidas }\end{array}$ & $Y=0,7309+0,53460 X$ & 0,95 \\
\hline Lâminas de folhas maduras & $Y=-0,5398+0,44861 X$ & 0,93 \\
\hline Colmos+bainhas & $Y=3,7440+0,93993 X$ & 0,98 \\
\hline Parte aérea & $Y=5,0883+2,00613 X$ & 0,98 \\
\hline
\end{tabular}

Resultados expressos em mg/vaso

No primeiro e segundo crescimentos da gramínea forrageira o acúmulo de magnésio nas folhas emergentes, nas lâminas de folhas recémexpandidas, nas lâminas de folhas maduras, nos colmos mais bainhas e na parte aérea aumentou linearmente com o aumento das doses de magnésio na solução. Os resultados indicaram que o capim-Mombaça, em ambos os crescimentos, pode acumular nos componentes da parte aérea e em toda a parte aérea maior quantidade deste nutriente quando cultivada em condições 
de disponibilidade mais elevada de magnésio que a utilizada nesse experimento.

A distribuição porcentual do magnésio acumulado nos componentes da parte aérea (folhas emergentes, lâminas de folhas recém-expandidas, lâminas de folhas maduras, colmos mais bainhas) em relação à parte aérea total do Panicum maximum cv. Mombaça, no primeiro e segundo crescimentos, em função das doses de magnésio na solução, é mostrada na Tabela 7.

Os maiores valores porcentuais de magnésio entre os componentes da planta foram observados nos colmos mais bainhas, no material de ambos os cortes da planta forrageira. Porém, no primeiro corte esta variação foi crescente nas três doses mais baixas do nutriente na solução; nas demais doses observoutse decréscimo nesses valores. Também no primeiro corte, os valores porcentuais de magnésio nos colmos mais bainhas não diferiram estatisticamente das lâminas de folhas recém-expandidas nas doses 1,2; 12 e $60 \mathrm{mg} \mathrm{L}^{-1}$.

Os menores valores porcentuais da distribuição de magnésio foram verificados nas folhas emergentes, em ambos os crescimentos. No primeiro crescimento esse porcentual decresceu até a dose $12 \mathrm{mg} \mathrm{L}^{-1}$ na solução, porém no segundo crescimento esses valores diminuíram em função do incremento de magnésio na solução. As folhas emergentes não diferiram significativamente das lâminas de folhas recém-expandidas apenas na dose de magnésio de $3,6 \mathrm{mg} \mathrm{L}^{-1}$, no segundo corte.

Nas lâminas de folhas recém-expandidas, o valores de porcentual de magnésio acumulado foram mais elevados que nas lâminas de folhas maduras, porém não houve diferenças significativas na dose de magnésio de $36 \mathrm{mg} \mathrm{L-1}$ no primeiro corte, e para o segundo corte nas doses de 3,6; 36; 48 e $60 \mathrm{mg} \mathrm{L}^{-1}$. 
Tabela 7. Valores porcentuais da distribuição de potássio nos componentes do Panicum maximum cv. Mombaça em relação ao magnésio acumulado na parte aérea nos dois períodos de crescimento, em função das doses de magnésio.

\begin{tabular}{|c|c|c|c|c|}
\hline \multirow{2}{*}{$\begin{array}{c}\text { Doses de Mg } \\
\left(\mathrm{mg} \mathrm{L}^{-1}\right)\end{array}$} & \multicolumn{4}{|c|}{ Parte da planta } \\
\hline & $\mathrm{FE}$ & LN & LM & CB \\
\hline \multicolumn{5}{|c|}{ Primeiro corte } \\
\hline 0 & $14,73 \mathrm{c}$ & $29,21 b$ & $11,65 \mathrm{c}$ & $44,41 \mathrm{a}$ \\
\hline 1,2 & $12,30 \mathrm{~b}$ & $29,45 \mathrm{a}$ & $13,20 \mathrm{~b}$ & $45,02 \mathrm{a}$ \\
\hline 3,6 & $11,34 \mathrm{c}$ & $24,75 b$ & $13,68 \mathrm{c}$ & $50,23 a$ \\
\hline 12 & $8,66 c$ & $33,10 a$ & $21,52 b$ & $36,72 \mathrm{a}$ \\
\hline 24 & $9,54 \mathrm{~d}$ & $31,44 b$ & $21,80 \mathrm{c}$ & $37,22 \mathrm{a}$ \\
\hline 36 & $8,69 \mathrm{c}$ & $29,43 b$ & $25,30 \mathrm{~b}$ & $36,58 \mathrm{a}$ \\
\hline 48 & $9,71 d$ & $30,10 \mathrm{~b}$ & $23,25 \mathrm{c}$ & $36,94 \mathrm{a}$ \\
\hline 60 & $9,03 \mathrm{c}$ & $35,27 \mathrm{a}$ & $25,53 \mathrm{~b}$ & $30,17 \mathrm{a}$ \\
\hline \multicolumn{5}{|c|}{ Segundo corte } \\
\hline 0 & $15,68 \mathrm{c}$ & $28,83 \mathrm{~b}$ & $9,12 \mathrm{c}$ & $46,37 \mathrm{a}$ \\
\hline 1,2 & $12,52 \mathrm{c}$ & $24,80 \mathrm{~b}$ & $9,77 \mathrm{c}$ & $52,91 \mathrm{a}$ \\
\hline 3,6 & $9,79 \mathrm{~b}$ & $23,04 \mathrm{~b}$ & $11,94 b$ & $55,23 a$ \\
\hline 12 & $7,16 \mathrm{c}$ & $22,57 \mathrm{~b}$ & $13,29 \mathrm{c}$ & $56,98 a$ \\
\hline 24 & $6,16 \mathrm{~d}$ & $23,47 \mathrm{~b}$ & $15,53 \mathrm{c}$ & $54,84 \mathrm{a}$ \\
\hline 36 & $6,73 \mathrm{c}$ & $22,96 \mathrm{~b}$ & $21,11 b$ & $49,20 \mathrm{a}$ \\
\hline 48 & $4,90 \mathrm{c}$ & $26,51 \mathrm{~b}$ & $19,49 \mathrm{bc}$ & $49,10 \mathrm{a}$ \\
\hline 60 & $4,75 \mathrm{c}$ & $28,07 \mathrm{~b}$ & $19,59 \mathrm{bc}$ & $47,59 \mathrm{a}$ \\
\hline
\end{tabular}

$\mathrm{FE}=$ Folhas emergentes; $\mathrm{LN}=$ Lâminas de folhas recém-expandidas; LM= Lâminas de folhas maduras; $\mathrm{CB}=$ Colmos+bainhas.

Letras diferentes nas linhas indicam diferenças significativa ao nível de 5\% de probabilidade (Tukey). 
Nas lâminas de folhas maduras, no primeiro corte ocorreu aumento nos valores porcentuais da distribuição de magnésio àmedida em que ocorreu a elevação das doses de magnésio na solução e esses valores estiveram entre 11 e $26 \%$. No segundo crescimento essa variação foi crescente com a concentração de magnésio na solução até a dose $36 \mathrm{mg} \mathrm{L}^{-1}$, sendo a variação de 9 a $21 \%$ do magnésio acumulado.

\subsubsection{Nível crítico de magnésio}

Houve alta correlação entre a concentração de magnésio nos componentes da parte aérea e a produção de massa seca da planta, no primeiro corte. Foram observados coeficientes de correlação da ordem de 0,86 para folhas emergentes; 0,89 para lâminas de folhas recém-expandidas; 0,72 para lâminas de folhas maduras e 0,84 para colmos mais bainhas. Assim, a amostragem das lâminas de folhas recém-expandidas é indicada para a avaliação do estado nutricional em magnésio no capim-Mombaça (Figura 41), pois entre os componentes da planta, essa parte expressou o mais alto coeficiente para essa correlação.

A utilização das lâminas de folhas recém-expandidas para avaliação do estado nutricional em magnésio é importante não apenas pela facilidade de amostragem do material, como também pela maior estabilidade dos resultados em comparação com a amostragem em que se utiliza toda a parte aérea.

O valor de nível crítico de magnésio nas lâminas de folhas recémexpandidas coletadas no primeiro corte para $90 \%$ da máxima produção foi de 4,2 $\mathrm{g} \mathrm{kg}^{-1}$ de massa seca (Figura 41). Este resultado está próximo ao encontrado por Cavalheiro \& Trindade (1992) em pastagens nativas do Rio Grande do Sul, em que tiveram intervalos de nível crítico de magnésio na ordem de 1,1 a $3,9 \mathrm{~g} \mathrm{~kg}^{-1}$ na primavera; 1,1 a $4,9 \mathrm{~g} \mathrm{~kg}^{-1}$ no verão; $1,0 \mathrm{a}$ $3,5 \mathrm{~g} \mathrm{~kg}^{-1}$ no outono e 0,7 a $3,2 \mathrm{~g} \mathrm{~kg}^{-1}$ no inverno. 
Werner \& Haag (1972) encontraram em lâminas de folhas recémexpandidas do capim-Colonião cultivado na solução nutritiva, concentrações de magnésio na ordem de $1,2 \mathrm{~g} \mathrm{~kg}^{-1}$ no tratamento completo e $0,5 \mathrm{~g} \mathrm{~kg}^{-1}$ na omissão de magnésio ra solução. Ressaltaram que concentrações mais altas desse nutriente foram encontradas nos colmos mais bainhas, tanto no tratamento completo $\left(2,7 \mathrm{~g} \mathrm{~kg}^{-1}\right)$ quanto na omissão do nutriente $\left(0,7 \mathrm{~g} \mathrm{~kg}^{-1}\right)$.

Monteiro et al. (1995) observaram na parte aérea de Brachiaria brizantha cv. Marandu, aos 50 dias após transplante, concentração de magnésio de $3,5 \mathrm{~g} \mathrm{~kg}^{-1}$ no tratamento completo e obtiveram $0,4 \mathrm{~g} \mathrm{~kg}^{-1}$ na ausência desse nutriente. Costa \& Gonçalves (1997) verificaram, na Brachiaria decumbens, concentração de magnésio da ordem de 3,4 e $2,3 \mathrm{~g} \mathrm{~kg}^{-1}$ na parte aérea das plantas no tratamento completo e na testemunha, respectivamente.

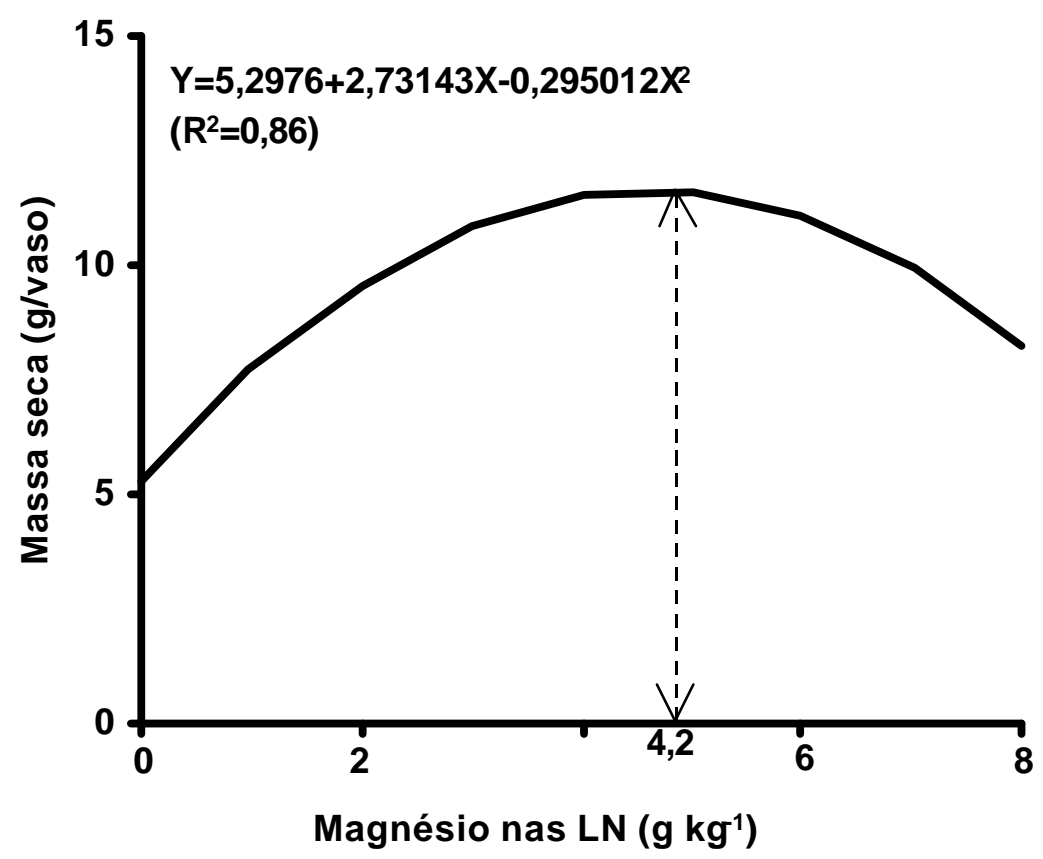

Figura 41 - Relação entre a concentração de magnésio nas lâminas de folhas recém-expandidas no primeiro corte e a produção de massa seca da parte aérea do Panicum maximum cv. Mombaça. 
Para o segundo crescimento, os resultados revelaram não haver significância $(P>0,05)$ para as correlações entre a concentração de magnésio nos componentes da parte aérea e a produção de massa seca da planta. Foram observados baixos valores nos coeficientes de correlação entre essas variáveis avaliadas $(0,46$ para folhas emergentes; 0,49 para lâminas de folhas recém-expandidas; 0,40 para lâminas de folhas maduras e 0,48 para colmos mais bainhas).

\subsubsection{Relação entre concentração de magnésio e valor SPAD}

Observou-se correlação significativa $(P<0,01)$ entre a concentração de magnésio e o valor SPAD, ambos avaliados nas lâminas de folhas recém-expandidas do Panicum maximum cv. Mombaça, no primeiro e segundo cortes. Os coeficientes de correlação entre essas variáveis foram de 0,76 para o primeiro corte e 0,73 para o segundo corte.

Nas Figuras 42 e 43 estão mostradas as equações e os valores SPAD medidos nas lâminas de folhas recém-expandidas em função da concentração de magnésio nas lâminas de folhas recém-expandidas nos dois períodos de crescimento da gramínea forrageira.

No primeiro crescimento obteve-se o nível critico em valor SPAD de 46 que correspondeu ao nível critico de magnésio de $4,2 \mathrm{~g} \mathrm{~kg}^{-1}$ de massa seca nas lâminas de folhas recém-expandidas. No segundo crescimento, verificoutse que a relação entre os valores SPAD nas lâminas de folhas recémexpandidas e a concentração de magnésio nas mesmas lâminas foliares mostrou valor SPAD de 37 unidades e concentração de magnésio de $3,2 \mathrm{~g} \mathrm{~kg}^{-1}$ de massa seca. 


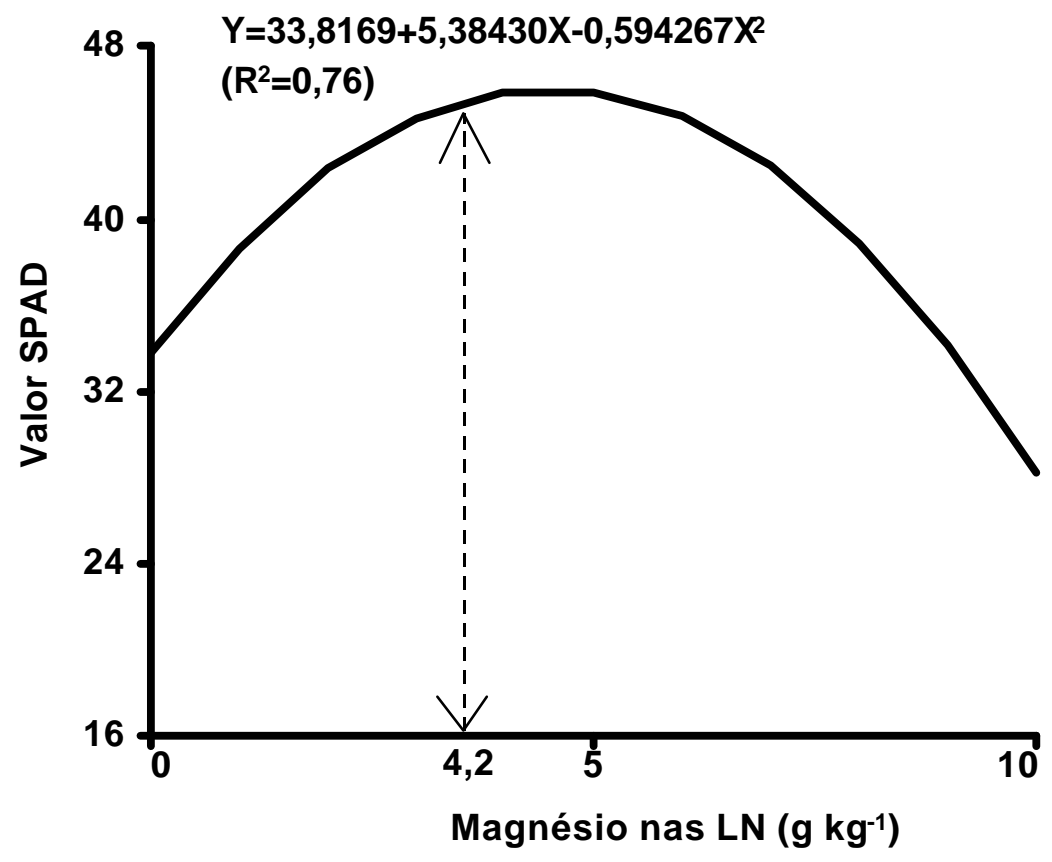

Figura 42 - Relação entre a concentração de magnésio nas lâminas de folhas recém- expandidas no primeiro corte e o valor SPAD medido nas lâminas de folhas recém-expandidas do capim-Mombaça.

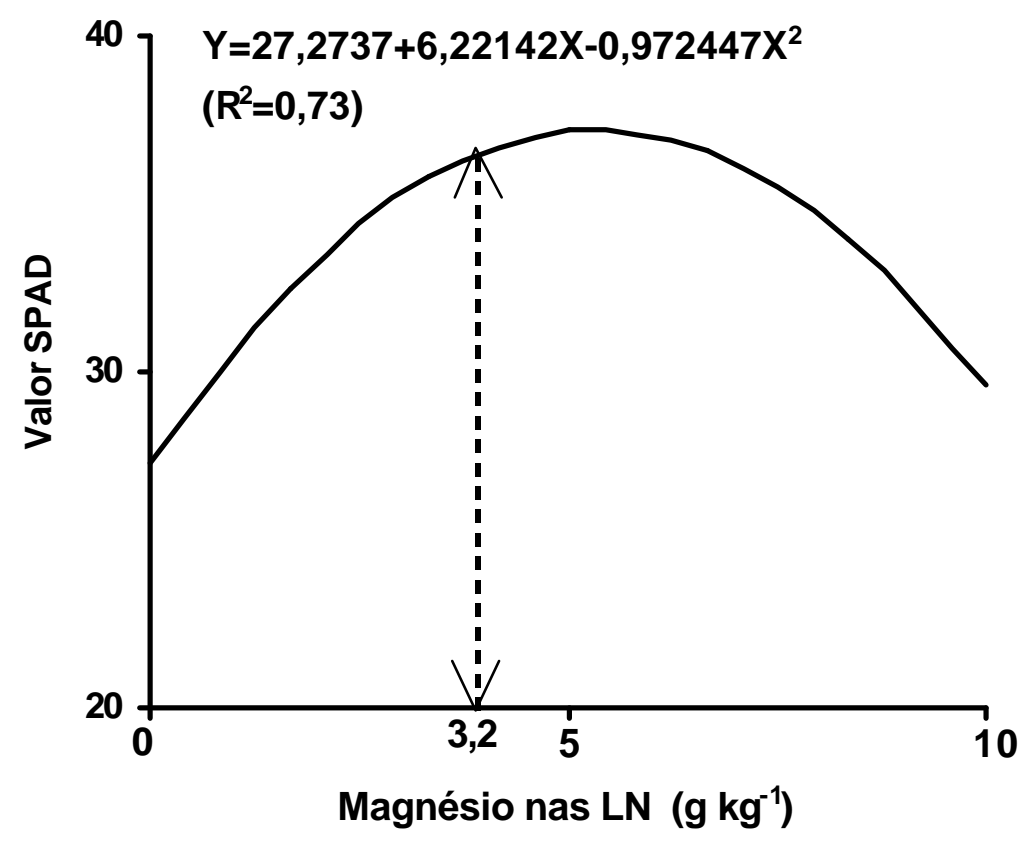

Figura 43 - Relação entre a concentração de magnésio nas lâminas de folhas recém-expandidas no segundo corte e o valor SPAD medido nas lâminas de folhas recém-expandidas do capim-Mombaça. 


\subsubsection{Relação K: Mg no capim-Mombaça}

$\mathrm{Na}$ Tabela 8 estão apresentados os resultados da relação entre as concentrações de potássio e de magnésio $(\mathrm{K}: \mathrm{Mg})$ nos componentes da parte aérea do Panicum maximum cv. Mombaça, em função das doses de magnésio na solução nutritiva, em ambos os crescimentos.

Os mais altos e mais baixos valores absolutos encontrados na relação entre as concentrações de potássio e magnésio ocorreram, respectivamente, nas lâminas de folhas maduras e nos colmos mais bainhas, tanto no primeiro como no segundo corte. Verifica-se também que os valores referentes a relação $\mathrm{K}: \mathrm{Mg}$ no capim-Mombaça decresceu em todos os componentes da planta com o incremento de magnésio na solução nutritiva.

No primeiro crescimento notourse que as menores variações entre 0 mais baixo e mais alto valor da relação $\mathrm{K}: \mathrm{Mg}$, em função das doses de magnésio na solução, foram encontradas nas folhas emergentes e nos colmos mais bainhas. A variação mais alta (8,76 vezes) nessa relação foi verificada nas lâminas de folhas maduras. Nesse crescimento da planta, as lâminas de folhas maduras foram o componente da planta mais afetado na relação $\mathrm{K}: \mathrm{Mg}$ quando se adicionou a dose mais elevada de magnésio na solução.

Também, no segundo crescimento as folhas emergentes e os colmos mais bainhas apresentaram as menores variações (3,45 e 9,17 vezes, respectivamente) nos valores da relação $\mathrm{K}: \mathrm{Mg}$. Assim como no primeiro corte, nas lâminas de folhas maduras foram verificados os mais altos valores dessa relação (na ordem de 16,26 vezes) e essa parte da planta forrageira também foi a mais afetada com o incremento de magnésio na solução.

As folhas emergentes diferiram significativamente das lâminas de folhas recém-expandidas, lâminas de folhas maduras e colmos+bainhas, em ambos os cortes, nas doses $12 ; 24 ; 36 ; 48$ e $60 \mathrm{mg} \mathrm{L}^{-1}$ de potássio. 
Tabela 8. Relação entre as concentrações de potássio e de magnésio (K:Mg) nos componentes da parte aérea do Panicum maximum cv. Mombaça em função das doses de magnésio na solução, nos dois cortes.

\begin{tabular}{|c|c|c|c|c|}
\hline \multirow{2}{*}{$\begin{array}{c}\text { Doses de } \mathrm{Mg} \\
\left(\mathrm{mg} \mathrm{L}^{-1}\right)\end{array}$} & \multicolumn{4}{|c|}{ Parte da planta } \\
\hline & $\mathrm{FE}$ & LN & LM & $\mathrm{CB}$ \\
\hline \multicolumn{5}{|c|}{ Primeiro corte } \\
\hline 0 & $30,45 \mathrm{c}$ & $41,63 \mathrm{bc}$ & $75,49 a$ & $48,01 \mathrm{~b}$ \\
\hline 1,2 & $34,76 a b$ & $35,04 a b$ & $42,00 \mathrm{a}$ & $30,72 b$ \\
\hline 3,6 & $29,43 a b$ & $26,52 b$ & $33,56 \mathrm{a}$ & $30,44 a b$ \\
\hline 12 & $25,25 \mathrm{a}$ & $16,95 b$ & $12,42 \mathrm{c}$ & $20,71 b$ \\
\hline 24 & $17,92 \mathrm{a}$ & $9,06 \mathrm{c}$ & $5,41 d$ & $12,03 b$ \\
\hline 36 & $14,62 \mathrm{a}$ & $7,57 \mathrm{c}$ & $4,20 d$ & $10,90 \mathrm{~b}$ \\
\hline 48 & $12,34 \mathrm{a}$ & $6,48 \mathrm{c}$ & $2,96 \mathrm{~d}$ & $8,01 \mathrm{~b}$ \\
\hline 60 & $10,52 a$ & $4,75 \mathrm{c}$ & $2,44 d$ & $7,15 b$ \\
\hline \multicolumn{5}{|c|}{ Segundo corte } \\
\hline 0 & $35,92 \mathrm{~b}$ & $49,12 b$ & $67,29 a$ & $46,13 b$ \\
\hline 1,2 & $43,74 a$ & $48,34 \mathrm{a}$ & $40,82 \mathrm{a}$ & $41,87 \mathrm{a}$ \\
\hline 3,6 & $37,96 \mathrm{a}$ & $33,77 \mathrm{ab}$ & $31,39 a b$ & $27,12 b$ \\
\hline 12 & $29,81 \mathrm{a}$ & $16,48 b$ & $12,51 \mathrm{~b}$ & $14,37 b$ \\
\hline 24 & $21,68 \mathrm{a}$ & $9,81 \mathrm{~b}$ & $6,22 \mathrm{c}$ & $9,86 b$ \\
\hline 36 & $15,02 a$ & $7,84 \mathrm{~b}$ & $3,84 \mathrm{~b}$ & $7,42 \mathrm{~b}$ \\
\hline 48 & $12,61 \mathrm{a}$ & $4,84 \mathrm{~b}$ & $3,03 \mathrm{c}$ & $5,53 \mathrm{~b}$ \\
\hline 60 & $10,40 a$ & $4,69 \mathrm{~b}$ & $2,60 \mathrm{c}$ & $5,03 \mathrm{~b}$ \\
\hline
\end{tabular}

FE= Folhas emergentes; LN= Lâminas de folhas recém-expandidas; LM= Lâminas de folhas maduras; $\mathrm{CB}=$ Colmos+bainhas.

Letras diferentes nas linhas indicam diferenças significativa ao nível de 5\% de probabilidade (Tukey). 
De acordo com Malavolta et al. (1997) o valor adequado da relação $\mathrm{K}: \mathrm{Mg}$ varia entre 7 e 10 . Nesse experimento foi encontrado essa ordem de valores nas lâminas de folhas recém-expandidas e nos colmos mais bainhas nas doses de magnésio de 36; 48 e $60 \mathrm{mg} \mathrm{L}^{-1}$ na solução, tanto no primeiro como no segundo corte. Ainda segundo Malavolta et al. (1997) se a concentração absoluta de $\mathrm{Mg}$ for relativamente baixa, os sintomas de deficiência de magnésio poderão aparecer se o quociente dessa relação for da ordem de 15 a 20. Essa magnitude de valores foi ultrapassada nas doses de magnésio de 0; 1,2 e 3,6 $\mathrm{mg} \mathrm{L}^{-1}$, em ambos os cortes e os sintomas de deficiência de magnésio foram observados com nitidez no presente estudo. Entretanto, nas plantas crescidas na dose de magnésio de $12 \mathrm{mg} \mathrm{L}^{-1}$ verificouse apenas coloração mais clara nas lâminas de folhas maduras.

\subsubsection{Sintomas visuais de deficiência de magnésio}

Aos treze dias após o transplante das mudas foram verificados os primeiros sintomas visuais de deficiência de magnésio no primeiro crescimento do Panicum maximum cv. Mombaça. Constatourse que as plantas submetidas à omissão de magnésio apresentavam nas lâminas de folhas maduras uma coloração verde mais clara com presença clorose interneval, além de crescimento reduzido. Por ocasião do primeiro corte, aos 29 dias após o transplante nas plantas crescidas, nas doses de magnésio de 1,2 e 3,6 $\mathrm{mg} \mathrm{L}^{-1}$ foram encontrados sintomas semelhantes aos daqueles da omissão do nutriente.

Dez dias após o primeiro corte da gramínea forrageira foram observados sintomas de deficiência de magnésio em plantas cultivadas na ausência do nutriente (Figura 44). Na ocasião do segundo corte, aos 50 dias após transplante, nas plantas desenvolvidas nas doses de magnésio de $0 ; 1,2$ e 3,6 $\mathrm{mg} \mathrm{L}^{-1}$, foram observados os mesmos sintomas verificados na época do primeiro corte, porém de modo mais intenso (Figura 45). 

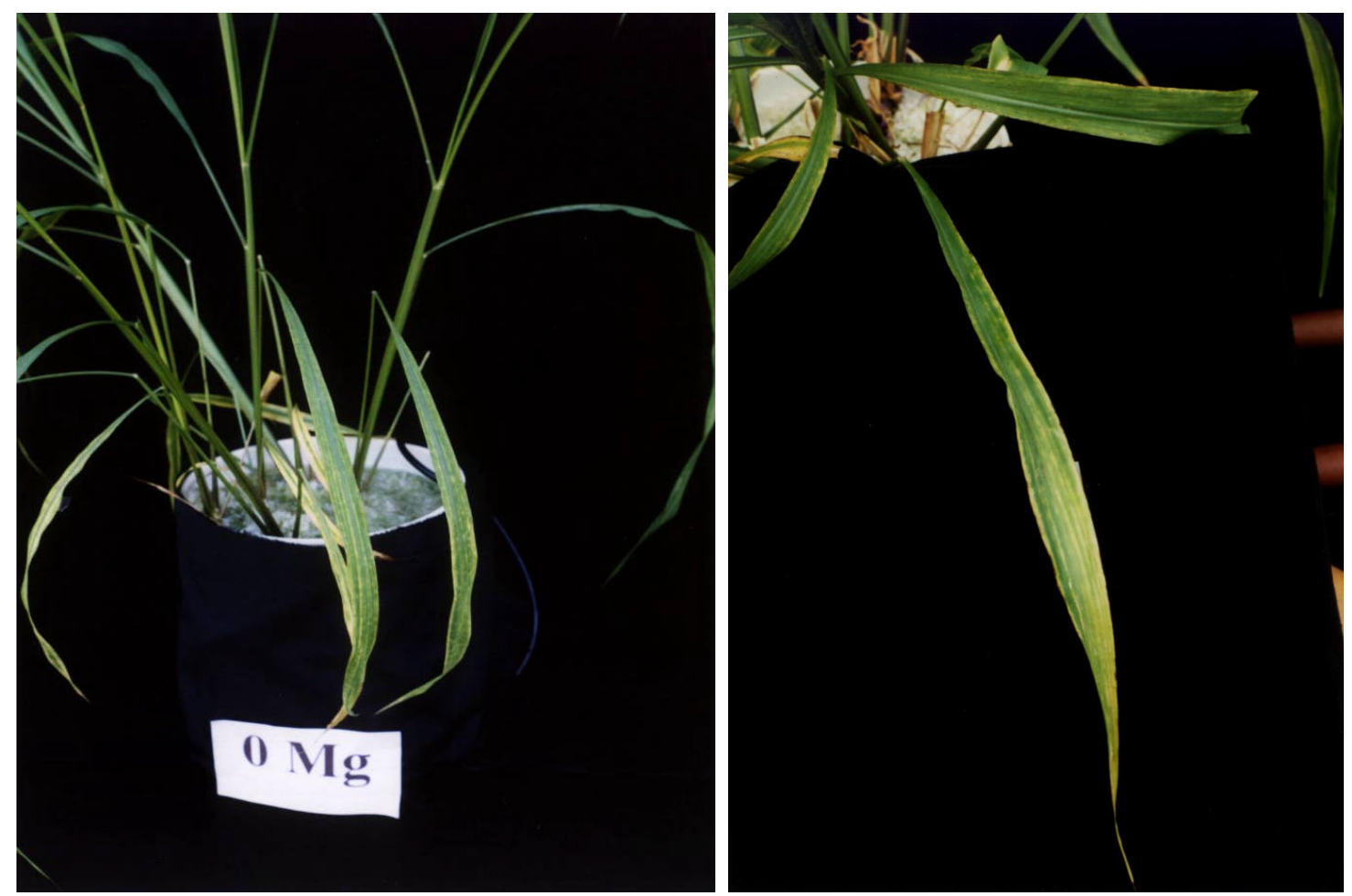

Figura 44 - Sintomas de deficiência de magnésio em lâminas de folhas maduras do Panicum maximum cv. Mombaça, verificados na ausência de fornecimento de magnésio na solução nutritiva.

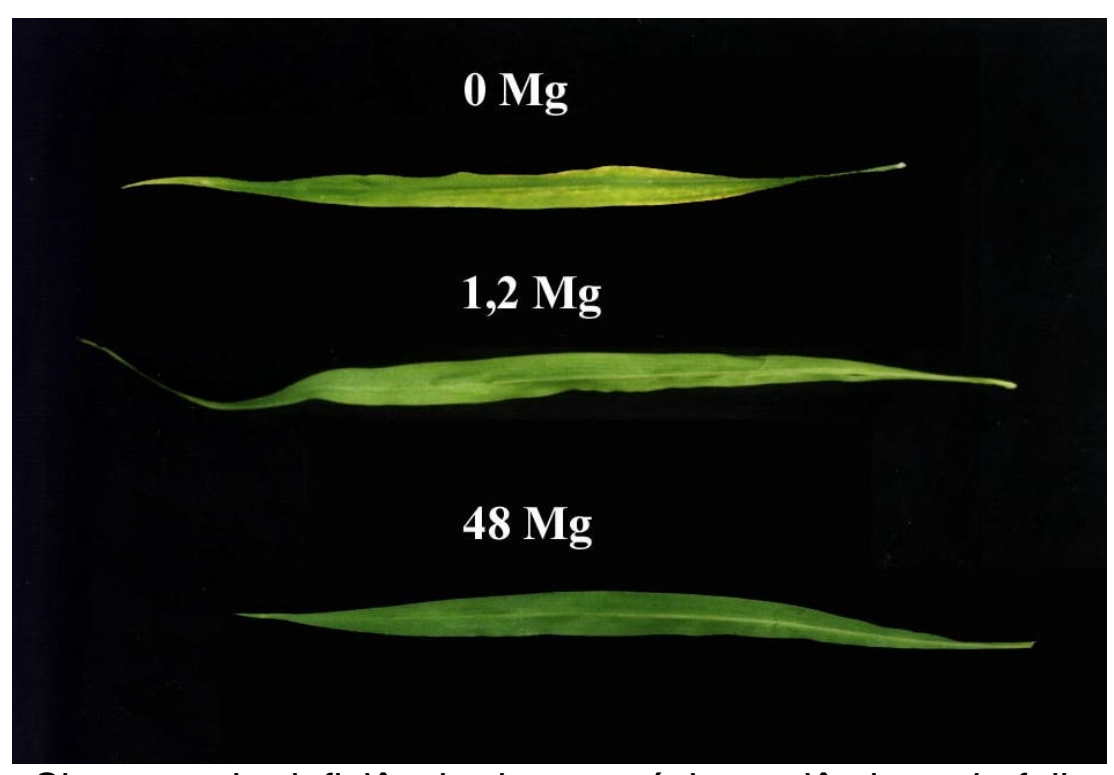

Figura 45 - Sintomas de deficiência de magnésio em lâminas de folhas maduras do Panicum maximum cv. Mombaça verificados nas doses de magnésio de 0 e $1,2 \mathrm{mg} \mathrm{L}^{-1}$ de solução, ao lado de lâmina similar em magnésio de $48 \mathrm{mg} \mathrm{L}^{-1}$. 
As plantas que receberam magnésio em $12 \mathrm{mg} \mathrm{L}^{-1}$ apresentavam nas lâminas de folhas maduras uma coloração verde mais clara que as das demais doses (24; 36; 48 e $60 \mathrm{mg} \mathrm{L}^{-1}$ ), mas não mostraram clorose internerval. Constatourse também a senescência precoce das folhas, e essa afetou principalmente as plantas que recebiam até a dose $3,6 \mathrm{mg} \mathrm{L}^{-1}$.

$\mathrm{O}$ aparecimento da deficiência de magnésio em lâminas de folhas maduras deve-se ao fato da mobilidade do nutriente, onde o elemento se transloca das folhas e órgãos mais velhos para suprir as necessidades nutricionais dos órgãos mais novos, de modo que a carência típica (clorose internerval e coloração verde-claro) surgem nas partes mais maduras. Esses sintomas são característicos de deficiência de magnésio mostrados na literatura.

França \& Haag (1985) observaram que nas plantas desenvolvidas na omissão de magnésio em capim-Tobiatã, as folhas apresentavam uma coloração verde-pálida, seguida de amarelecimento, com intensas pontuações necróticas.

Sarkis et al. (1996), em experimento com solução nutritiva, verificaram que nas doses de magnésio de 0 e 1,2 $\mathrm{mg} \mathrm{L}^{-1}$ foram observados os sintomas de deficiência (clorose internerval nas lâminas de folhas maduras) em Brachiaria brizantha e acrescentaram que a rebrota das plantas foi menos vigorosa nessas doses que nas demais estudadas. 


\section{CONCLUSÕES}

- A produção de massa seca da parte aérea, das raízes, o número de perfilhos e área foliar do capim-Mombaça, são altamente dependentes de adequado suprimento tanto de potássio como de magnésio no substrato.

- O magnésio na solução alterou positivamente a leitura do valor SPAD nas lâminas de folhas recém-expandidas, o que não foi observado em relação ao potássio.

- Predominou aumento nas concentrações de potássio e magnésio nas folhas emergentes, nas lâminas de folhas recém-expandidas, nas lâminas de folhas adultas, nos colmos mais bainhas e nas raízes em função do incremento das doses destes nutrientes em solução.

- O maior acúmulo de potássio e de magnésio foi observado nos colmos mais bainhas, enquanto que os menores acúmulos destes nutrientes foram verificados nas lâminas de folhas adultas e nas folhas emergentes.

- As lâminas de folhas recém-expandidas são indicadas para a avaliação do estado nutricional de potássio e de magnésio no capim-Mombaça. O nível crítico para o potássio variou entre 15,37 e $17,30 \mathrm{~g} \mathrm{~kg}^{-1}$ e para o magnésio foi de $4,2 \mathrm{~g} \mathrm{~kg}^{-1}$ na matéria seca. 


\section{REFERÊNCIAS BIBLIOGRÁFICAS}

ALFAYA, H.; EICHELBERGER,L.; SILVA, J.B. et al. Flutuação sazonal dos teores de potássio e magnésio no solo e na vegetação de áreas de campo natural não perturbado. In: REUNIÃO ANUAL DA SOCIEDADE BRASILEIRA DE ZOOTECNIA, 35., Botucatu, 1998. Anais. Botucatu: Sociedade Brasileira de Zootecnia, 1998. p. 99-101.

ALMEIDA, J.C.R. Combinação de doses de fósforo e magnésio na produção e nutrição de duas braquiárias. Piracicaba, 1998. 81p. Dissertação (Mestrado) - Escola Superior de Agricultura "Luiz de Queiroz", Universidade de São Paulo.

ANDRADE, J.B. Estudo comparativo de três capins da espécie Panicum maximum Jacq. (Colonião, Tobiatã e K-187 B). Piracicaba, 1987. 133p. Dissertação (Mestrado) - Escola Superior de Agricultura "Luiz de Queiroz", Universidade de São Paulo.

ANDRADE, J.B.; PAULINO, V.T.;FERRARI JÚNIOR, E. et al. Resposta de Panicum maximum à fertilização nitrogenada e potássica. In: REUNIÃO ANUAL DA SOCIEDADE BRASILEIRA DE ZOOTECNIA, 33., Fortaleza, 1996. Anais. Fortaleza: Sociedade Brasileira de Zootecnia, 1996. p.280-282.

ARNON, D.I. Copper enzymes in isolated chloroplasts: polyphenoloxydase in Beta vulgaris. Plant Physiology, v.24, n.1, p.1-15, 1949. 
ARONOVICH, S. O capim colonião e outros cultivares de Panicum maximum Jacq.: Introdução e evolução do uso no Brasil. In: SIMPOÓSIO SOBRE MANEJO DE PASTAGEM, 12., Piracicaba, 1995. Anais. Piracicaba: FEALQ, 1995. p.120.

BARBOSA, M.A.A.F.; DAMASCENO, J.C.; CECATO, U. et al. Influência da eliminação do meristema apical no aparecimento de perfilhos em quatro cultivares de Panicum maximum Jacq. In: REUNIÃO ANUAL DA SOCIEDADE BRASILEIRA DE ZOOTECNIA, 33., Fortaleza, 1996. Anais. Fortaleza: Sociedade Brasileira de Zootecnia, 1996. p.104-105.

BENETTI, I.; MONTEIRO, F.A. Doses de potássio na produção e composição química do capim-Vencedor. In: SIMPÓSIO DE INICIAÇÃO CIENTÍFICA DA UNIVERSIDADE DE SÃO PAULO, Piracicaba, 1999. Resumos. São Paulo: Universidade de São Paulo, 1999. p.314.

BLACKMER, T.M.; SCHEPERS, J.S.; VARVEL, G.E. Light reflectance compared with other nitrogen stress measurements in corn leaves. Agronomy Journal, v.86, n.6, p.934-938, 1994.

BRAGA, J.M. Potássio. In: CURSO DE FERTILIDADE E MANEJO DO SOLO, Viçosa, 1996. Fertilidade e manejo do solo. Brasília: ABEAS, 1996. mód. 8, 62p.

BRISKE, D.D. Plant response to defoliation: morphological considerations and allocation priorities. In: JOOS, P. J.; LYNCH, P. W.; WILLIAMS, O.B. (Ed.) Randelands: a resouce under siege. Canberra: Australian Academic Science, 1986. p. 425-427. 
CAMPBELL, R.J.; MOBLEY, K.N.; MARINI, R.P. et al. Growing conditions alter the relationship between SPAD-501 values and apple leaf chlorophyll. HortScience, v.25, n.3, p. 330-331, 1990.

CAPIM Mombaça: nova alternativa para a diversificação de pastagem. A Lavoura, n. 605, p. 30-31, 1994.

CARRIEL, J.M.; WERNER, J.C.; ABRAMIDES, P.L.G. et al. Limitações nutricionais de um solo Podzólico vermelho Amarelo para o cultivo de três gramíneas forrageiras. Boletim de Indústria Animal, v.46, n.1, p.61-73, 1989.

CARVALHO, D.D; MATTHEW, C.; BARONI, L.G. Particão da matéria seca e perfilhamento em três cultivares de Panicum maximum (Jacq.) submetidos a dois níveis de defolhação. In: REUNIÃO ANUAL DA SOCIEDADE BRASILEIRA DE ZOOTECNIA, 36., Porto Alegre, 1999. Anais. Porte Alegre: Sociedade Brasileira de Zootecnia, 1999. p.84.

CARVALHO M.M.; MARTINS, C.E.; VERNEQUE, R. S. et al. Resposta de uma espécie de braquiária à fertilização com nitrogênio e potássio em um solo ácido. Revista Brasileira de Ciência do Solo, v.15, n.2, p.195-200, 1991.

CAVALHEIRO, A.C; TRINDADE, D.S. Concentrações de cálcio, magnésio, sódio e potássio em pastagens nativas do Rio Grande do Sul. Revista Brasileira de Zootecnia, v.21, n.3, p.418-427, 1992. 
CECATO, U.; BARBOSA, A.A.F.B.;SAKAGUTI, E.S. et al. Avaliação de cultivares de Panicum maximum Jacq. In: REUNIÃO ANUAL DA SOCIEDADE BRASILEIRA DE ZOOTECNIA, 33., Fortaleza, 1996. Anais. Fortaleza: Sociedade Brasileira de Zootecnia, 1996. p.109-111.

CHAPMAN, D.F.; LEMAIRE, G. Morphogenetic and structural determinants of plant regrowth after defoliation. In: INTERNATIONAL GRASSLAND CONGRESS, 17., Palmerston North, 1993. Proceedings. Palmerston North: New Zealand Grassland Association, 1993. p.95-104.

CENTRO INTERNACIONAL DE AGRICULTURA TROPICAL. Informe anual 1981: programa de pastos tropicales. Cali, 1982. p. 171-194: Suelos/ nutricion plantas.

CENTRO INTERNACIONAL DE AGRICULTURA TROPICAL. Informe anual 1983: programa de pastos tropicales. Cali, 1984. p. 179-203: Suelos/ nutricion plantas.

COELHO, E.M.; CECATO, U.; BARBOSA, M.A.F. et al. Características do perfilhamento em quatro cultivares de Panicum maximum Jacq. In: REUNIÃO ANUAL DA SOCIEDADE BRASILEIRA DE ZOOTECNIA, 36., Porto Alegre, 1999. Anais. Porte Alegre: Sociedade Brasileira de Zootecnia, 1999. p.55.

COELHO, F.S.; VERLENGIA, F. Fertilidade do solo. São Paulo: IEA, 1973. $384 p$. 
COLOZZA, M. T. Rendimento e diagnose foliar dos capins Aruana e Mombaça cultivados em Latossolo-Amarelo adubado com doses de nitrogênio. Piracicaba, 1998. 127p. Tese (Doutorado) - Escola Superior de Agricultura "Luiz de Queiroz", Universidade de São Paulo.

CORRÊA, B.D. Doses de nitrogênio e de magnésio afetando aspectos produtivos e bioquímicos dos capins Colonião, Tanzânia-1 e Vencedor. Piracicaba, 1996. 76p. Dissertação (Mestrado) - Escola Superior de Agricultura "Luiz de Queiroz", Universidade de São Paulo.

CORRÊA, B.D.; MONTEIRO, F.A. Doses de nitrogênio e de magnésio produção de matéria seca e perfilhamento nos capins colonião, Tanzânia-1 e Vencedor (compact disc). In: CONGRESSO BRASILEIRO DE CIÊNCIA DO SOLO, 26., Rio de Janeiro, 1997. Resumos. Viçosa: Sociedade Brasileira de Ciência do Solo, 1997.

CORSI, M. Effects of nitrogen rates and harvesting intervals on dry matter production, tillering and quality of the tropical grass Panicum maximum. Jacq. Wooster, 1984. 125p. Thesis (Ph.D) - Ohio State University.

CORSI, M.; SANTOS, P.M. Potencial de produção do Panicum maximum. In: SIMPÓSIO SOBRE MANEJO DA PASTAGEM, 12., Piracicaba, 1995. Anais. Piracicaba: FEALQ, 1995. p.275 -303.

COSTA, N.L.; GONÇALVES, C.A. Nutrientes limitantes ao crescimento de Brachiaria decumbens em Rondônia (compact disc). In: CONGRESSO BRASILEIRO DE CIÊNCIA DO SOLO, 26., Rio de Janeiro, 1997. Resumos. Viçosa: Sociedade Brasileira de Ciência do Solo, 1997. 
DALE, J.E. How do leaves grow ? Advances in cells and molecular biology are unraveling some of the mysteries of leaf development. Bioscience, v.42, n.6, p.423-432, 1992.

DEJOU, J.; MONTARD, F.X. Efecto positivo que ejercen los abonados potassio y magnésio em suelos volcánicos del Maazo Central francés. Evolucion de $\mathrm{K}^{+}$en el suelo y en la planta al final de cinco años de cultivo de ballico perene. Revista de la Potassa, v.7, n.3, p.1-10, 1982.

DIAS FILHO, M.B.; SIMÃO NETO, M.; SERRÃO, E.A.S. Avaliação da adaptação de acessos de Panicum maximum para a Amazônia Oriental de Brasil. Pastures Tropicales, v.17, n.1, p.3-8, 1995.

EPSTEIN,E. Nutrição mineral das plantas: princípios e perspectivas. Trad. por E. Malavolta. Rio de Janeiro: Livros Técnicos e Científicos, 1975. 341p.

FAQUIN, V.; HOFFMANN, C.R.; EVANGELISTA, A.R. et al. O potássio e o enxofre no crescimento de braquiária e do colonião em amostras de um Latossolo da região Noroeste do Paraná. Revista Brasileira de Ciência do Solo, v.19, n.3, p.87-94, 1995.

FERRAGINE, M.C. Combinação de doses de nitrogênio e potássio na nutrição mineral de capim-braquiária. Piracicaba, 1998. 84p. Dissertação (Mestrado) - Escola Superior de Agricultura "Luiz de Queiroz", Universidade de São Paulo.

FERRARI NETO, J. Limitações nutricionais para o colonião (Panicum maximum Jacq.) e braquiária (Brachiaria decumbens Stapf.) em Latossolo da Região Noroeste do Estado do Paraná. Lavras, 1991. 126p. Dissertação (Mestrado) - Escola Superior de Agricultura de Lavras. 
FERRARI NETO, J.; FAQUIN, V.; VELE, F.R. et al. Limitações nutricionais para o colonião (Panicum maximum Jacq.) e braquiária (Brachiaria decumbens Stapf.) em Latossolo da Região Noroeste do Estado do Paraná: I. Produção de matéria seca e perfilhamento. Revista Brasileira de Zootecnia, v.23, n.4, p.539-551, 1994.

FONSECA, J.A.; MEURER, E.J. Antagonismo entre potássio e magnésio em plantas de milho. In: CONGRESSO BRASILEIRO DE CIÊNCIA DO SOLO, 25., Viçosa, 1995. Anais. Viçosa: Sociedade Brasileira de Ciência do Solo, 1995. p.1034-1035.

FOX, R.H.; PIEKIELEK, W. P.; MACNEAL, K. M. Using a chorophyll meter to predict nitrogen fertilizer needs of winter wheat. Communications in Soil Science and Plant Analysis, v.25, n.3/4, p.171-181, 1994.

FRANÇA, A.F.S.; HAAG, H.P. Nutrição mineral de gramíneas tropicais. I. Carências nutricionais de capim-Tobiatã (Panicum maximum Jacq.). Anais da Escola Superior de Agricultura "Luiz de Queiroz", v.62, p.83-95, 1985.

GALLO, J.R.; HIROCE, R.; BATAGLIA, O.C. et al. Composição química inorgânica de forrageiras do Estado de São Paulo. Boletim de Indústria Animal, v. 31, n.1, p.115-137, 1974.

GASTAL, F.; BELANGER, G.; LEMAIRE, G. A model of the leaf extention rate of tall fescue in response to nitrogen and temperature. Annals of Botany, v.70. n.5, p.437-442, 1992. 
GOMIDE, A.M. Morfogênese e análise de crescimento de cultivares de Panicum maximum (Jacq.). Viçosa, 1997. 53p. Dissertação (M.S.) - Universidade Federal de Viçosa.

GOMIDE, J.A. Estudos em pequenas parcelas sobre a fertilização do capim gordura (Melinis minutiflora Pal. De Beauv). Revista Ceres, v.13, n.75, p.165-181, 1966.

GOMIDE, J.A.; OBEID, J.A.; RODRIGUES, L.R.A. Fatores morfológicos de rebrota do capim-colonião (Panicum maximum). Revista da Sociedade Brasileira de Zootecnia, v.8, n.4, p.532-562, 1979.

GOMIDE, J.A.; ZAGO, C.P.; RIBEIRO, A.C. et al. Calagem, fontes de fósforo e níveis de fósforo no estabelecimento e produção de capim-colonião (Panicum maximum Jacq.) no cerrado. Revista da Sociedade Brasileira de Zootecnia, v.15, n.3, p.241-246, 1986.

GUIMARÃES, T.G.; FONTES, P.C.R.; PEREIRA, P.R.G. et al. Teores de clorofila determinados por medidor portátil e sua relação com formas de nitrogênio em folhas de tomateiro cultivados em dois tipos de solos. Bragantia, v.58, n.1, p. 209-216, 1999.

HAAG, H.P.; MELLO, F.A.F.; BRASIL SOBRINHO, M.C. et al. Estudos sobre a nutrição mineral do Pennisetum purpureum Schum., var. Napier cultivado em solução nutritiva. In: INTERNATIONAL GRASSLAND CONGRESS, 9., São Paulo, 1965. Proceedings. São Paulo: Secretaria de Agricultura do Estado de São Paulo, 1965. p.691-695. 
HARTT, C.E. Effect of potassium deficiency upon translocation of ${ }^{14} \mathrm{C}$ in attached blades and entire plants of sugar cane. Plant Physiology, v.44, n.3, p.1461-1469, 1969.

HAY, R.K.M.; WALKER, A.J. An introduction to the physiology of crop yield. Nova York: Logman Scientific and Technical, 1989.292p.

HERLING, V.R.; JANTALIA, C.P. ; PIAZZA, C. et al. Fisiologia de perfilhamento do capim-Mombaça (Panicum maximum Jacq. cv. Mombaça) sob pastejo. In: REUNIÃO ANUAL DA SOCIEDADE BRASILEIRA DE ZOOTECNIA, 35., Botucatu, 1998. Anais. Botucatu: Sociedade Brasileira de Zootecnia, 1998. p. 533-534.

HERLING, V.R.; ZANETI, M.A.; GOMIDE, C.A. et al. Influência de níveis de adubações nitrogenada e potássica e estádios de crescimento sobre o capim Setária (Setária anceps Stapf. Ex. Massey cv. Kazungula). I - Produção de matéria seca e fisiologia de perfilhamento. Revista da Sociedade Brasileira de Zootecnia, v.20, n.6, p.561-571, 1991.

HODGSON, J. Grazing management: science into pratice. Essex: Longman Scientific and Technical, 1990.203p.

HOEL, B.; SOLHAUG, K.A. Effect of irradiance on chlorophyll estimation with the Minolta SPAD-502 leaf chlorophyllmetre. Annals of Botany, v.82, n.3, p.389-392, 1998.

HOFFMANN, C.R. Nutrição mineral e crescimento da braquiária e do colonião, sob influência das aplicações de nitrogênio, fósforo, potássio e enxofre em Latossolo da Região Noroeste do Paraná. Lavras, 1992. 204p. Dissertação (Mestrado) - Escola Superior de Agricultura de Lavras. 
HOFFMANN, C.R.; FAQUIN, V.; GUEDES, G.A.A. et al. Níveis críticos de nitrogênio, fósforo, potássio e enxofre em braquiária e colonião, cultivados em Latossolo da região noroeste do Paraná. In: REUNIÃO BRASILEIRA DE FERTILIDADE DO SOLO E NUTRIÇÃO DE PLANTAS, 20., Piracicaba, 1992. Resumos. Petrolina: Universidade Federal de Petrolina, 1992. p.102-103.

HUMPHRIES, E.C.; WHEELER, A.W. The physiology of leaf growth. Annual Review of Plant Physiology, v.45, p.385-405, 1963.

INGESTAD, T. Nutrition and growth of birch and grey alder seedlings in low conductivity solutions and at varied relative rates of nutrient addition. Physiologia Plantarum, v. 52, n.4, p.454-466, 1981.

JANK, L. Melhoramento e seleção de variedades de Panicum maximum. In: SIMPÓSIO SOBRE MANEJO DA PASTAGEM, 12., Piracicaba, 1995. Anais. Piracicaba: FEALQ, 1995. p.21-58.

JANK, L.; SADIVAN, Y.; SOUZA, M.T. et al. Avaliação do germoplasma de Panicum maximum introduzido da África. 1. Produção forrageira. Revista da Sociedade Brasileira de Zootecnia, v.23, n.3, p.433-440, 1994.

KORTE, C.J. Tillering in "Grasslands Nui" perennial ryegrass swards. 2. Seasonal pattern of tillering and age of flowering tillers with two mowing frequencies. New Zeland Journal of Agricultural Research, v.29, n.4, p.629-638, 1986.

LANGER, R.H.M. Tillering in herbage grasses. Herbage Abstracts, v.33, n.3, p.141-148, 1963. 
LANGER, R.H.M. How grasses grow. London: Edward Arnold, 1974. 66p.

$\mathrm{LOCH}$, D.S. Selection of environmental and cropping system for tropical grasses. In: INTERNATIONAL GRASSLAND CONGRESS, 15., Kyoto, 1985. Proceedings. Kyoto: Science Council of Japan and Japanese Society of Grassland Science, 1985, p.95-104.

LOPES, A.S. Solos sob "cerrado": características, propriedades e manejo. Piracicaba: Associação Brasileira para Pesquisa de Potassa e do Fosfato, 1984. 162p.

LOPES, N.F.; OLIVA, M.A.; FREITAS, J.G. et al. Análise de crescimento e conversão da energia solar em feijoeiro (Phaseolus vulgaris L.) submetido a três níveis de densidade do fluxo radiante. Revista Ceres, v.29, n.166, p.586-606, 1982.

MALAVOLTA, E. Manual de química agrícola, nutrição de plantas e fertilidade do solo. São Paulo: Ave Maria, 1976. 528 p.

MALAVOLTA, E. Elementos de nutrição de mineral de plantas. São Paulo: Agronômica Ceres, 1980. 251 p.

MALAVOLTA, E.; VITTI, G.C.; OLIVEIRA, S.A. de. Avaliação do estado nutricional de plantas: princípios e aplicações. 2.ed. Piracicaba: Associação Brasileira para Pesquisa de Potassa e do Fosfato, 1997. 319p.

MARUN, F. Produção de matéria seca e nutrição mineral de gramíneas forrageiras em função da relação $\mathrm{Ca} / \mathrm{Mg}$ do corretivo. Lavras, 1990. 81p. Dissertação (Mestrado) - Escola Superior de Agricultura de Lavras. 
MATTOS, W.T. Diagnose nutricional de potássio em duas espécies de Braquiária. Piracicaba, 1997. 74p. Dissertação (Mestrado) - Escola Superior de Agricultura "Luiz de Queiroz", Universidade de São Paulo.

MATTOS, W.T.; MONTEIRO, F.A. Concentração de magnésio nas partes da Brachiaria decumbens submetida a doses de potássio. In: REUNIÃO BRASILEIRA DE FERTILIDADE DO SOLO E NUTRIÇÃO DE PLANTAS, 23., Caxambu, 1998a. Resumos. Lavras: Universidade Federal de Lavras, 1998a. p.278.

MATTOS, W.T.; MONTEIRO, F.A. Respostas de Brachiaria brizantha a doses de potássio. Scientia Agricola, v.55, n.3, p.428-437, 1998b.

MATTOS, W.T.; SILVA, A.A.; SANTOS, A.R. et al. Produção de matéria seca e concentração de potássio em capim-Tanzânia-1 (Panicum maximum) submetido a doses de potássio em solução nutritiva (compact disc). In: CONGRESSO LATINO-AMERICANO DE CIÊNCIA DO SOLO, 13., Águas de Lindóia, 1996. Solo-suelo 96: trabalhos. Piracicaba: Sociedade Brasileira de Ciência do Solo/SLCS, 1996.

MAYLAND, H.F.; GRUNES, D.L. Soil-climate-plant relationships in the etiology of grass tetany. In: RENDING, V. V.; GRUNES, D. L. (Ed.) Grass tetany. Madison: Aus tralian Academic Science, 1979. p.123-175.

MEIRI, A.; SILK, W.K.; LAUCHLI, A. Growth and deposition of inorganic nutrient elements in developing leaves of Zea mays L. Plant Physiology, v.99, n.3, p.972-978, 1992.

MELLO, F.A.F.; BRASIL SOBRINHO, M.O.C.; ARZOLLA, S. et al. Fertilidade do solo. São Paulo: Nobel, 1989. 400p. 
MINOLTA CAMERA CORPORATION. Manual for chlorophyll meter SPAD502. Osaka, 1989. 22p.

MINOTTI, P. L.; HALSETH, D. E.; SIECZKA, J.B. Field chlorophyll measurements to assess the nitrogen status of potato varieties. HortScience, v.29, n.12, p.1497-1500, 1994.

MITIDIERI, J. Manual de gramíneas e leguminosas para pastos tropicais. São Paulo: Nobel, 1983. 198p.

MIYASAKA, S.; OKAMATO, H. Importância da matéria orgânica na agricultura. In: ENCONTRO SOBRE MATÉRIA ORGÂNICA DO SOLO: PROBLEMAS E SOLUÇÕES, Botucatu, 1992. Anais. Botucatu: UNESP, Faculdade de Ciências Agronômicas, 1992. p. 1-24.

MONTEIRO, F.A.; WERNER, J.C. Reciclagem de nutrientes nas pastagens. In: SIMPÓSIO SOBRE MANEJO DE PASTAGEM, 14., Piracicaba, 1997. Anais. Piracicaba: FEALQ, 1997. p.55-84.

MONTEIRO, F.A.; FRARE, P.M.; ONO, M.N. Magnésio, cálcio e potássio no tecido foliar de Brachiaria decumbens submetida a doses de magnésio. In: REUNIÃO BRASILEIRA DE FERTILIDADE DO SOLO E NUTRIÇÃO DE PLANTAS, 23, Caxambu, 1998. Resumos. Lavras: Universidade Federal de Lavras, 1998. p.532.

MONTEIRO, F.A; BALSALOBRE, M.A.A.; MANZANO, R.P. et al. Combinação de doses de potássio e magnésio em solução nutritiva para os parâmetros produtivos de braquiária Marandu (compact disc). In: REUNIÃO ANUAL DA SOCIEDADE BRASILEIRA DE ZOOTECNIA, 36., Porto Alegre, 1999. Anais. Porte Alegre: Sociedade Brasileira de Zootecnia, 1999. 
MONTEIRO, F.A.; LIMA, S.A.A.; WERNER, J.C. et al. Adubação potássica em leguminosas e em capim-colonião (Panicum maximum Jacq.) adubado com níveis de nitrogênio ou consorciado com leguminosas. Boletim de Indústria Animal, v.37, n.1, p.127-147, 1980.

MONTEIRO, F.A.; RAMOS, A.K.B.; CARVALHO, D.D. et al. Cultivo de Brachiaria brizantha Stapf. cv. Marandu em solução nutritiva com omissões de macronutrientes. Scientia Agricola, v.52, n.1, p.135-41, 1995.

MORIKAWA. C.K. Limitações nutricionais para o andropogon (Andropogon gayanus) e braquiarão (Brachiaria brizantha) em Latossolo da região do Campos das Vertentes - MG. Lavras, 1993. 136p. Dissertação (Mestrado) - Escola Superior de Agricultura de Lavras.

NABINGER, C. Eficiência do uso de pastagens: disponibilidade e perdas de forragem. In: SIMPÓSIO SOBRE MANEJO DA PASTAGEM, 14., Piracicaba, 1997. Anais. Piracicaba: FEALQ, 1997. p. 213-251.

NASCIMENTO, M.P.S.C.B.; NASCIMENTO, H.T.S.; GOMIDE, J.A. Alguns aspectos morfofisiológicos de três gramíneas de clima tropical. Revista Brasileira de Zootecnia, v.9, n.1, p.142-158, 1980.

NEILSEN,D.; HOGUE, E.L.; NEILSEN, G.H et al. Using SPAD-502 to assess the nitrogen status of apple trees. HortScience, v.30, n.3, p.508-512, 1995.

NELSON, C.J.; ZARROUGH, K.M. Tiller density and tiller weight as yield determinants of vegetative swards. In : WRIGTH, C.E. (Ed.) Plant physiology and herbage production. Hurley, British Grassland Society, 1981.p.25-29. 
PAULINO, V.T.; SCHUNKE, R.; CANTARELLA, H. Avaliação do nível de nitrogênio em quatro cultivares de Panicum maximum Jacq. através da medida indireta de clorofila. In: REUNIÃO ANUAL DA SOCIEDADE BRASILEIRA DE ZOOTECNIA, 35., Botucatu, 1998. Anais. Botucatu: Sociedade Brasileira de Zootecnia, 1998. p. 508-511.

PAULINO, V.T.; WERNER, J. C.; CARRIEL , J. M. et al. Estudos de adubação com Brachiaria humidicola e Setaria anceps cv. Kazungula em dois solos de várzea do estado de São Paulo. Zootecnia, v.24, n.2, p.181-206, 1986.

PEARSE, P.J.; WILMAN, D. Effects of applied nitrogen on grass leaf initiation, development and death in field swards. Journal of Agricultural Science, v.103, n.2, p.405-413, 1984.

PENG, S.; LAZA, M.R.C.; GARCIA, F.V. et al. Chlorophyll meter estimates leaf area-based nitrogen concentration of rice. Communication in Soil Science and Plant Analysis, v.26, n.5/6, p.927-935, 1995.

PIEKIELEK, W.P.; FOX, R.H. Use of chlorophyll meter to predict sidedress nitrogen requirements for maize. Agronomy Journal, v.84, n.1, p.59-65, 1992.

PREMAZZI, L.M. Saturação por bases como critério para recomendação de calagem em cinco forrageiras tropicais. Piracicaba, 1991. 215p. Dissertação (Mestrado) - Escola Superior de Agricultura "Luiz de Queiroz", Universidade de São Paulo. 
RAIJ, B.van. Disponibilidade de potássio em solos do Brasil. In: SIMPÓSIO SOBRE POTÁSSIO NA AGRICULTURA BRASILEIRA, Londrina, 1892. Anais. Piracicaba: Associação Brasileira para Pesquisa de Potassa e do Fosfato, 1982. p.67- 94.

RAIJ, B.van. Fertilidade do solo e adubação. São Paulo: Agronômica Ceres; Associação Brasileira para Pesquisa da Potassa e do Fosfato, 1991. 343p.

RAO, I. M.; KERRIDGE, P.C.; MACEDO, M.C.M. Nutritional requiriments of Brachiaria and adaptation to acid soil. In: MILES, J. W.; MAAS, B. L.; VALLE, C. B. do (Ed.) Brachiaria: biology, agronomy and improvement. Cali: CIAT; EMBRAPA, 1996. p.53-71.

RODRIGUES, A.C.G.; ROSSIELLO, R.O.P. Crescimento, absorção de K, Ca e $\mathrm{Mg}$ de forrageiras tropicais em função da adubação potássica. In: CONGRESSO BRASILEIRO DE CIÊNCIA DO SOLO, 25., Viçosa, 1995. Resumos. Viçosa: Sociedade Brasileira de Ciência do Solo, 1995. p.12521254.

SANTOS, A.R. Diagnose nutricional e respostas de capim-braquiária submetido a doses de nitrogênio e enxofre. Piracicaba, 1997. 115p. Tese (Doutorado) - Escola Superior de Agricultura "Luiz de Queiroz", Universidade de São Paulo.

SANTOS, J.Q. Fertilização: fundamentos de utilização dos adubos e corretivos. São Paulo: Coleção EUROAGRO, 1992. 439p. 
SANTOS, P.M. Estudo de algumas características agronômicas de Panicum maximum (Jacq.) cvs. Tanzânia e Mombaça para estabelecer seu manejo. Piracicaba, 1997. 62p. Dissertação (Mestrado) - Escola Superior de Agricultura "Luiz de Queiroz", Universidade de São Paulo.

SARKIS, F.; FRARE, P.M.; MONTEIRO, F.A. Distribuição da parte aérea da Brachiaria brizantha submetida a doses de magnésio em solução nutritiva. In: SIMPÓSIO DE INICIAÇÃO CIENTÍFICA DA UNIVERSIDADE DE SÃO PAULO, Piracicaba, 1996. Resumos. São Paulo: Universidade de São Paulo, 1996. p.444.

SARRUGE, J.R. Soluções nutritivas. Summa Phytopathologica, v.1, n.3, p.231-233, 1975.

SARRUGE, J.R.; HAAG, H.P. Análises químicas de planta. Piracicaba: ESALQ, 1974. 56p.

SAS INSTITUTE. The SAS-system for windows: release 6.11 (software). Cary, 1996.

SAVIDAN, Y.H.; JANK, L.; COSTA, J.C.G. Registro de 25 acessos selecionados de Panicum maximum. Campo Grande: EMBRAPA, CNPGC, 1990. 68p. (EMBRAPA. CNPGC. Documentos, 44).

SERRÃO, E.A.S.; SIMÃO NETO, M. Informações sobre duas espécies de gramíneas forrageiras do gênero Brachiaria (Brachiaria decumbens Stapf. e Brachiaria ruziziensis) na Amazônia. Belém: IPEAN, 1971. 31p. (IPEAN. Boletim Técnico, 2). 
SILVA, A.A.; MATTOS, W.T.; MONTEIRO, F.A. Respostas de capim Tanzânia -1 (Panicum maximum) a níveis de potássio em solução nutritiva. In: CONGRESSO BRASILEIRO DE CIÊNCIA DO SOLO, 25., Viçosa, 1995. Resumos. Viçosa: Sociedade Brasileira de Ciência do Solo, 1995. p.10461047.

SILVA, A.A.; MATTOS, W.T.; MONTEIRO, F.A. et al. Potássio e sódio em capim Tanzânia -1 cultivado em solução nutritiva. (compact disc) In: CONGRESSO BRASILEIRO DE CIÊNCIA DO SOLO, 26., Rio de Janeiro, 1997. Resumos. Viçosa: Sociedade Brasileira de Ciência do Solo, 1997.

SILVA, N.M.A. Produtividade e composição mineral das gramíneas forrageiras Andropogon cv. Planaltina e Colonião cv. Tobiatã submetidas a níveis de potássio, cálcio e sódio. Piracicaba, 1992. 91p. Dissertação (Mestrado) - Escola Superior de Agricultura "Luiz de Queiroz", Universidade de São Paulo.

SKERMAN,P. J.; RIVEROS, F. Gramineas tropicales. Roma: FAO, 1982. 849p. (Coleção FAO. Producción y Protección Vegetal, 23).

SKINNER, R.H.; NELSON, C.J. Role of leaf appearance rate and coleoptile tiller in regulating production. Crop Science, v.34, n.1, p.71-75, 1994.

SOARES, E. Influência da relação entre teores trocáveis de cálcio e magnésio do solo na absorção de potássio pelo centeio (Secale cereale L.). Piracicaba, 1975. 73p. Dissertação (Mestrado) - Escola Superior de Agricultura "Luiz de Queiroz", Universidade de São Paulo. 
SOARES, E. Influência do teor de potássio trocável do solo na absorção de cálcio e magnésio pela soja [Glycine max (L.) Merril]. Piracicaba, 1978. 116p. Tese (Doutorado) - Escola Superior de Agricultura "Luiz de Queiroz", Universidade de São Paulo.

TEIXEIRA, L.B. Dinâmica do ecossistema de pastagem cultivada em área de floresta na Amazônica Central. Manaus, 1987. 100p. Tese (Doutorado) - Fundação Universidade do Amazonas.

THOMAS, H.; STODDART, J.L. Leaf senescence. Annual Review of Plant Physiology, v.31, p.83-111, 1980.

TOLEDO, J.M. Pasturas en trópico húmero: perspectiva global. In: SIMPÓSIO DO TRÓPICO ÚMIDO, 1., Belém, 1984. Anais. Belém: EMBRAPA, CPATU, 1986. p.19-36.

TRUZZI, K.D.C.; DECHEN, A.R.; MONTEIRO, F.A. Níveis de potássio e magnésio para milho cultivado em solução nutritiva. In: CONGRESSO BRASILEIRO DE CIÊNCIA DO SOLO. 25., Viçosa, 1995. Anais. Viçosa: Sociedade Brasileira de Ciência do Solo, 1995. p.1036-1037.

TURNER, F.T.; JUND, M.F. Chlorophyll meter to predict nitrogen topdress requirement for semidwarf rice. Agronomy Journal, v.83, n.1, p.926-928, 1991.

ULRICH, A. Physiological basis for assessing the nutritional requirements of plants. Plant Physiology, v.27, n.3, p.207-228, 1976. 
ULRICH, A.; HILLS, F.J. Plants analysis as an aid fertilizing sugar crops: part I. Sugar beets. Principales and pratices of plant analysis. In: WALSH, L.M.; BEATON, J.D. (Ed.) Soil testing and plant analysis. Madison: Soil Science Society of America, 1973. p.271-288.

URETA, C. F. Fertilization de la vid. EI Campesiano, n.6, p. 25 - 34, 1981.

VALLEJOS, A.; PIZARRO, E. A.; CHAVES, C. et al. Evaluación agronómica de gramineas en Guapiles, Costa Rica. 2. Ecotipos de Panicum maximum. Pasturas Tropicales, v.11, n.2, p.10-15, 1989.

VENTURA, C.A.O. Níveis de potássio, cálcio e magnésio em solução nutritiva influenciando o crescimento e composição da soja [Glycine max (L.) Merril], cultivar Paraná. Piracicaba, 1987. 70p. Tese (Doutorado) - Escola Superior de Agricultura "Luiz de Queiroz" ”, Universidade de São Paulo.

VICENTE-ChANDLER, J.; PEARSON, R. W.; ABRÑA, F. et al. Potassium fertilization of intensively managed grasses under tropical conditions. Agronomy Journal, v. 54, n.5, p.450-453,1962.

WATSON, D.J. The physiological basis of variation in yeld. Advances in Agronomy, v.4. p.101-145, 1952.

WERNER, J.C. Adubação de pastagens. Balde Branco, n.230, p.40-480, 1983.

WERNER, J.C. Adubação potássica. In: SIMPÓSIO SOBRE CALAGEM E ADUBAÇÃO DE PASTAGENS, 1., Nova Odessa. 1985. Anais. Piracicaba: Associação Brasileira para Pesquisa de Potassa e do Fosfato, 1986. p. 175190. 
WERNER, J. C.; HAAG, H. P. Estudos sobre a nutrição mineral de alguns capins tropicais. Boletim de Indústria Animal, v.29, n.1, p.191-245, 1972.

WILKINSON, R. R.; LOWREY, R. W. Cycling of mineral nutrients in pasture ecosystems. In: BUTLER, G. W.; BAILEY, R. W. (Ed.) Chemistry and biochemistry of herbage. London: Academic Press, 1973. v.2, p.247-315.

YADAVA, U. L. A rapid and nondestructive method to determine chlorophyll in intact leaves. HortScience, v.21, n.6, p.1449-1450, 1986. 